I N T ER N ATIONAL MONETARY FUND

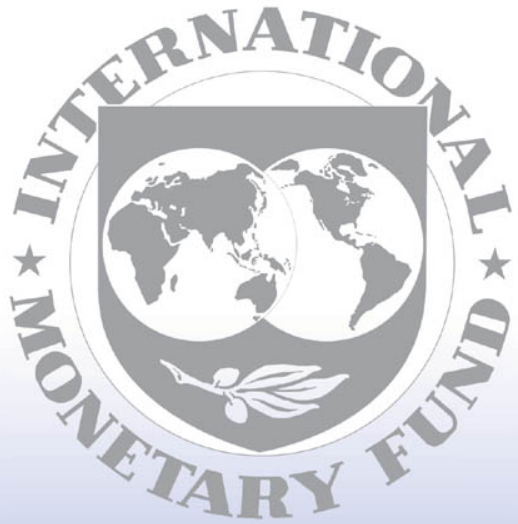

Staff

Country

Reports 


\section{Rwanda: Poverty Reduction Strategy Paper-Annual Progress Report}

Poverty Reduction Strategy Papers (PRSPs) are prepared by member countries in broad consultation with stakeholders and development partners, including the staffs of the World Bank and the IMF. Updated every three years with annual progress reports, they describe the country's macroeconomic, structural, and social policies in support of growth and poverty reduction, as well as associated external financing needs and major sources of financing. This country document for Rwanda, dated July 2005, is being made available on the IMF website by agreement with the member country as a service to users of the IMF website.

To assist the IMF in evaluating the publication policy, reader comments are invited and may be sent by e-mail to publicationpolicy@imf.org.

Copies of this report are available to the public from

International Monetary Fund • Publication Services

$70019^{\text {th }}$ Street, N.W. • Washington, D.C. 20431

Telephone: (202) 623-7430 • Telefax: (202) 623-7201

E-mail: publications@imf.org • Internet: http://www.imf.org

Price: $\$ 15.00$ a copy

\section{International Monetary Fund \\ Washington, D.C.}


This page intentionally left blank

CInternational Monetary Fund. Not for Redistribution 
REPUBLIC OF RWANDA

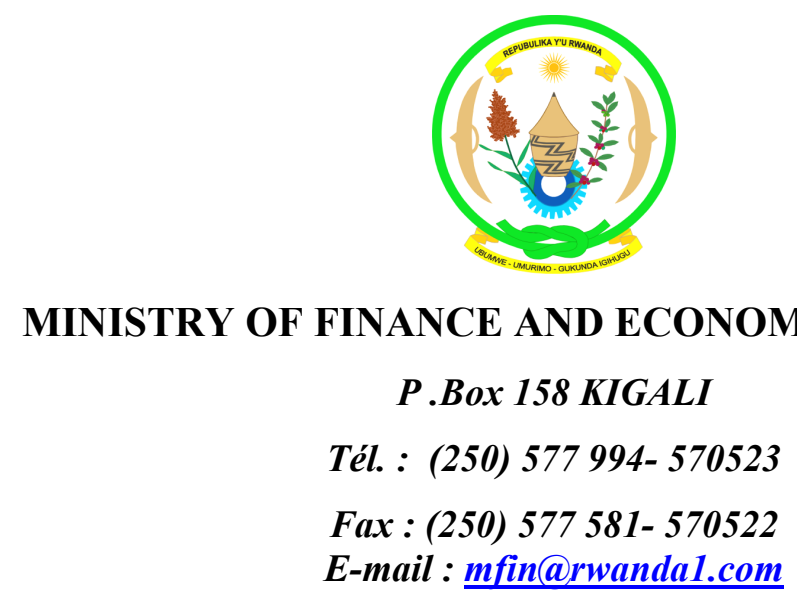

\section{Poverty Reduction Strategy}

Annual Progress Report

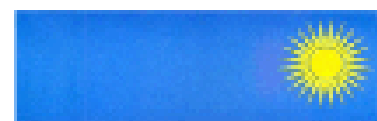

POLICY MATRIX

July 2005

CInternational Monetary Fund. Not for Redistribution 


\section{Table of Contents}

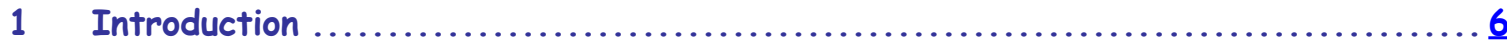

2 Executive Summary and Analytical Overview............................... 8

3 Macroeconomic Overview ................................................

3.1 Overall Macroeconomic Performance.................................................................................

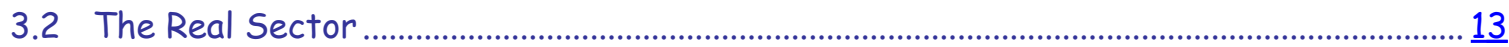

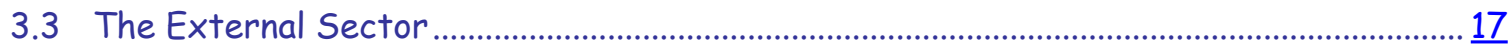

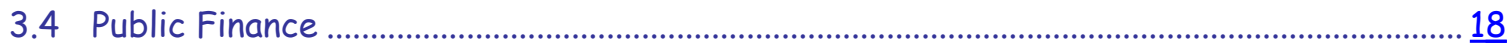

3.5 The Monetary Sector .......................................................................................................

3.6 Medium term macroeconomic framework ....................................................................... 21

4 Public Financial Management and Expenditures and Aid Harmonization ............23

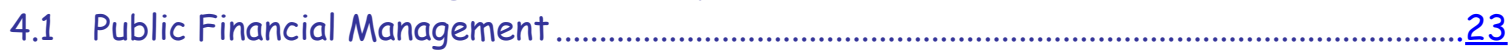

4.2 Fiscal Decentralization ......................................................................................................

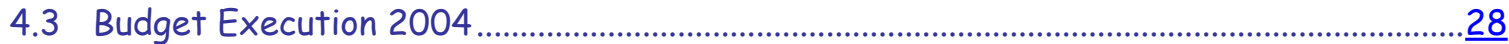

4.4 Aid Coordination and Harmonisation in 2004 .................................................................

5 Agricultural Transformation and Rural Development........................

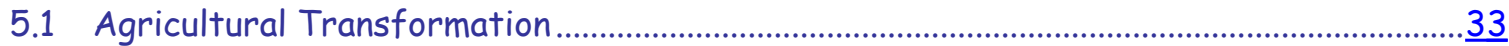

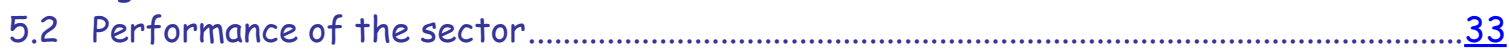

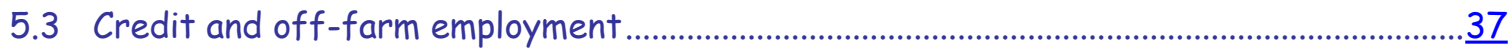

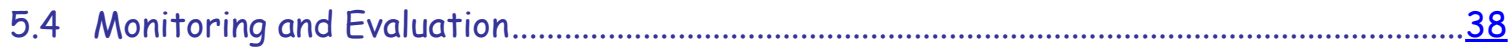

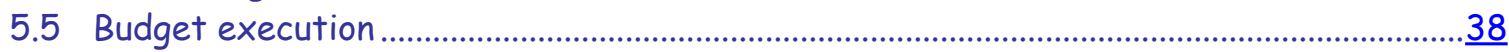

6 Cross cutting issue - Environment and Land .............................

7 Human Development - Health ........................................... 43

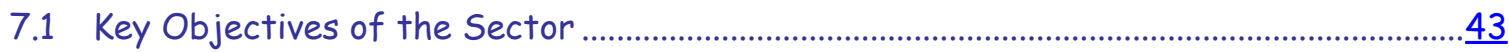

7.2 Key Indicators in the Health Sector ..........................................................................43

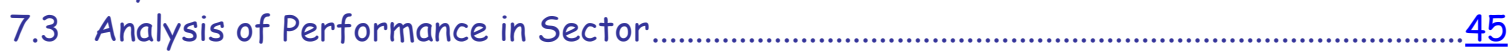

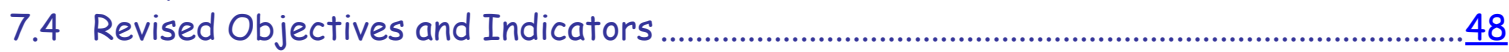

8 Cross cutting issue - HIV/AIDS ........................................

9 Human Development - Education ...................................... 54

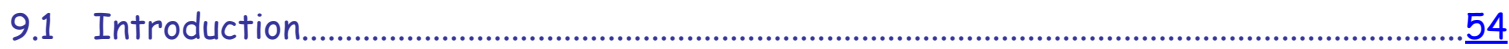

9.2 Key performance Indicators in Education and Training...................................................

9.3 Priority Delivery Areas.................................................................................................

9.4 Planning, Management and Financing ……………….........................................................

10 Human Development - Water and Sanitation ..............................61

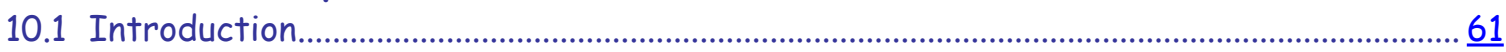

10.2 Key objectives and performance indicators for Water and Sanitation............................ 61

10.3 Progress assessment ....................................................................................................... 61

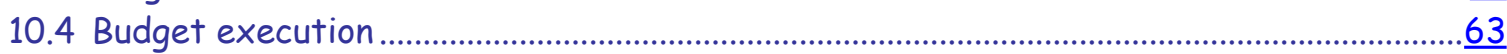


11 Capacity Building and Human Resource Development ......................64

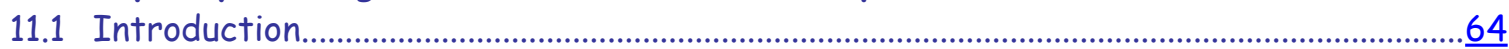

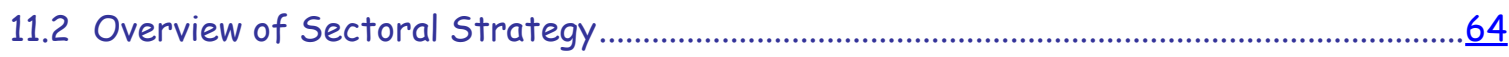

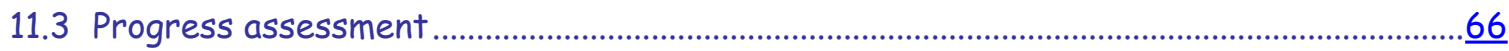

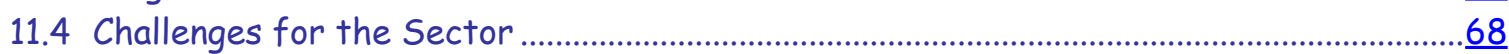

11.5 Modification of strategies and objectives since 2004 ....................................................69

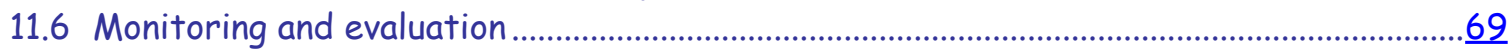

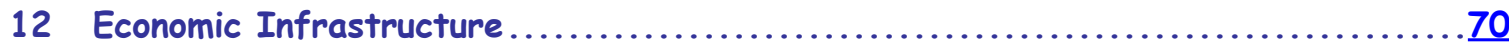

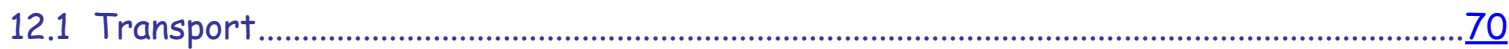

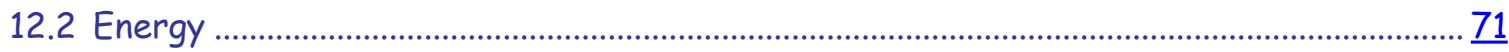

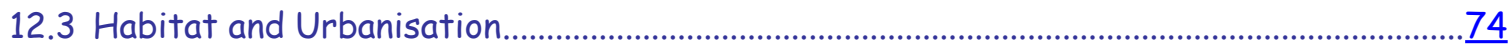

12.4 Cross cutting issue - Information Communications Technology ........................................

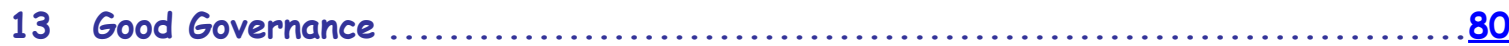

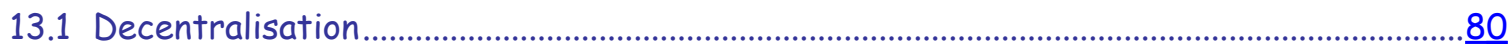

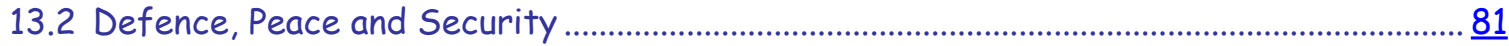

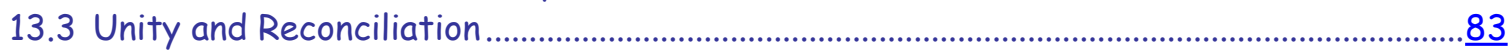

13.4 Criminal Justice System, Human Rights and Gacaca ......................................................... $\frac{84}{86}$

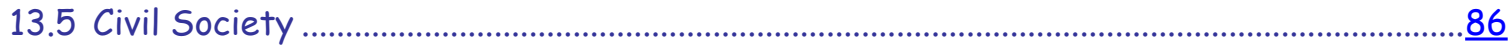

13.6 Democratisation, Transparency and Accountability ......................................................

14 Commercial Sector Development .......................................... 88

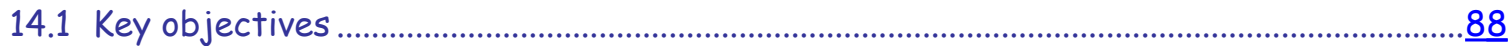

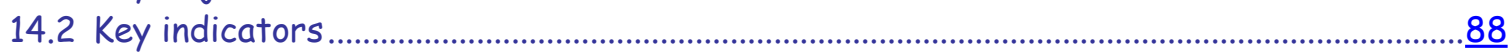

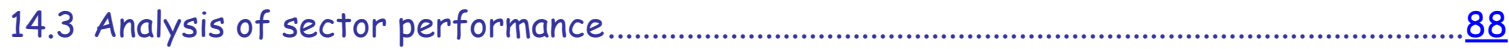

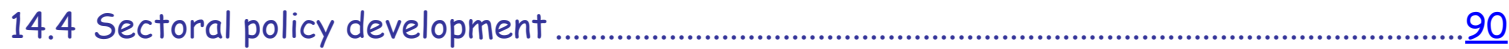

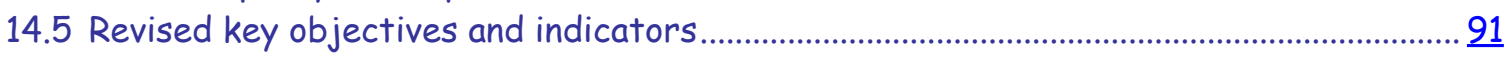

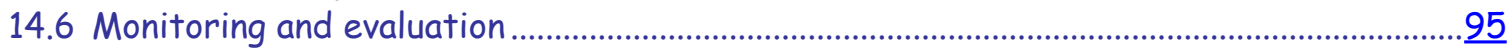

14.7 Annex MINICOM: Budget Execution...............................................................................

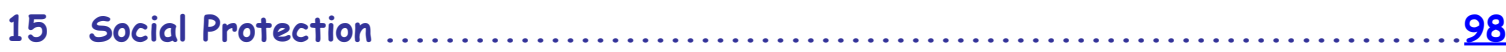

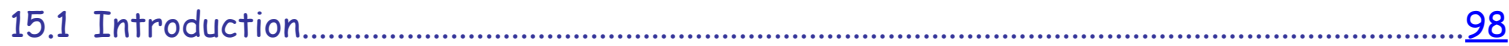

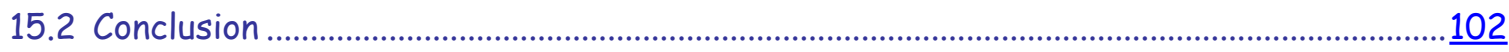

16 Cross cutting issue - Gender ........................................ 104

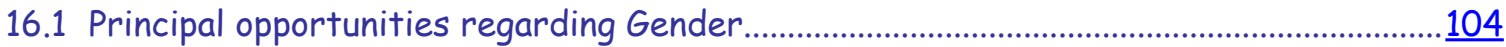

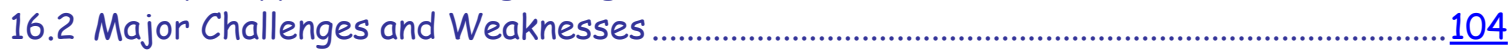

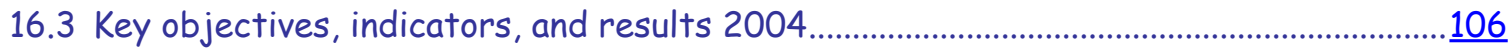

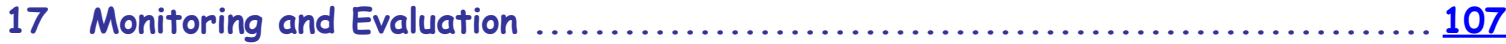

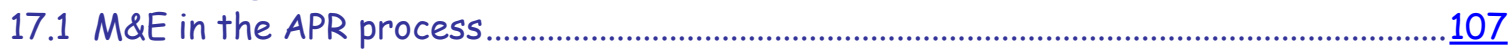

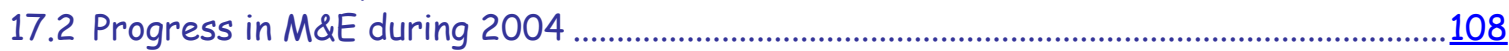

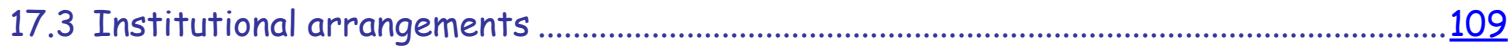

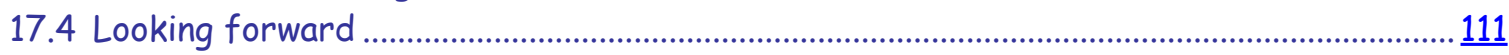

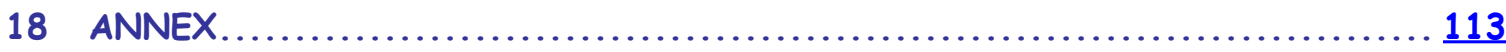




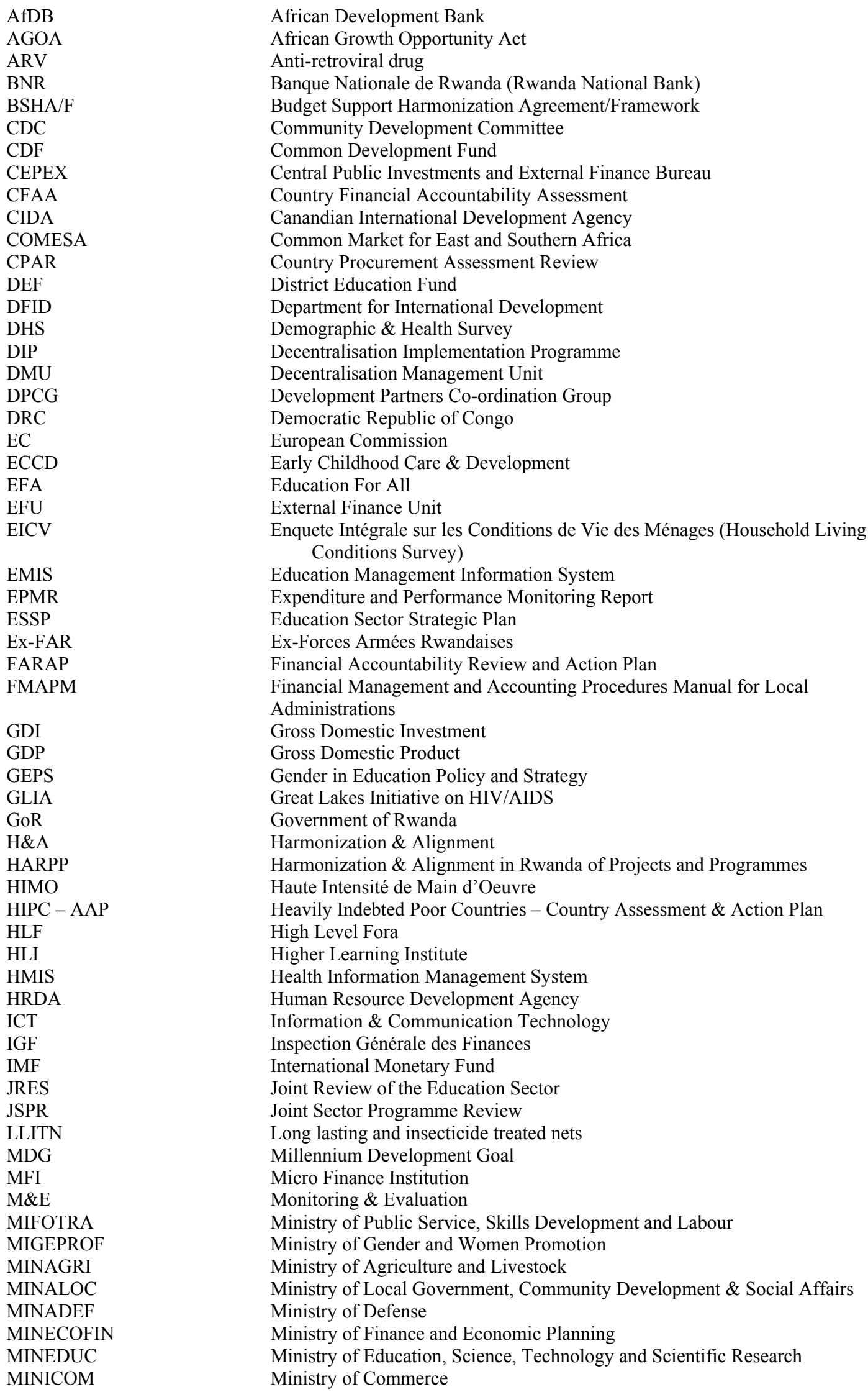

African Development Bank

African Growth Opportunity Act

Banque Nationale de Rwanda (Rwanda National Bank)

Budget Support Harmonization Agreement/Framework

Common Development Fund

Central Public Investments and External Finance Bureau

Country Financial Accountability Assessment

Canandian International Development Agency

Demographic \& Health Survey

Decentralisation Implementation Programme

Decentralisation Management Unit

Development Partners Co-ordination Group

Democratic Republic of Congo

European Commission

Care \& Development

External Finance Unit

Enquete Intégrale sur les Conditions de Vie des Ménages (Household Living Conditions Survey)

Expenditure and Performance Monitoring Report

Education Sector Strategic Plan

Financial Accountability Review and Action Plan

Financial Management and Accounting Procedures Manual for Local

Administrations

Government of Rwanda

Harmonization \& Alignment

Harmonization \& Alignment in Rwanda of Projects and Programmes

Intensité de Main d'Oeuvre

High Level Fora

Higher Learning Institute

Health Information Management System

Human Resource Development Agency

Information \& Communication Technology

Inspection Generale des Finance

ry Fund

Joint Sector Programme Review

Long lasting and insecticide treated nets

Millennium Development Goal

Ministry of Public Service, Skills Development and Labour

Ministry of Gender and Women Promotion

Ministry of Agriculture and Livestock

Ministry of Local Government, Community Development \& Social Affairs

Mefense

Ministry of Education, Science, Technology and Scientific Research

Ministry of Commerce 


\begin{tabular}{|c|c|}
\hline MINIJUST & Ministry of Justice \\
\hline MININFRA & Ministry of Infrastructure \\
\hline MININTER & Ministry of the Interior \\
\hline MINISANTE & Ministry of Health \\
\hline MIS & Management Information System \\
\hline MSCBP & Multi Sector Capacity Building Programme \\
\hline MTEF & Medium Term Expenditure Framework \\
\hline NCHE & National Council For Higher Education \\
\hline NDIS & National Decentralisation Implementation Secretariat \\
\hline NDSC & National Decentralisation Steering Committee \\
\hline NEC & National Electoral Commission \\
\hline NEPAD & New Economic Partnership for African Development \\
\hline NGO & Non Governmental Organisation \\
\hline NHRC & National Human Rights Commission \\
\hline NIS & National Investment Strategy \\
\hline NTB & National Tender Board \\
\hline NURC & National Unity \& Reconciliation Commission \\
\hline OAG & Office of the Auditor General \\
\hline OBL & Organic Budget Law \\
\hline $\mathrm{OECD} / \mathrm{DAC}$ & $\begin{array}{l}\text { Organisation for Economic Co-operation \& Development / Development } \\
\text { Assistance Committee }\end{array}$ \\
\hline OPDAS & Organisation of African First Ladies \\
\hline ORTPN & Rwandan Office of Tourism and National Parks \\
\hline PAYA & Panafrican Youth Organisation against AIDS \\
\hline PEPFAR & President Bush's Emergency Plan for AIDS Relief \\
\hline PER & Public Expenditure Review \\
\hline PETS & Public Expenditure Tracking Survey \\
\hline PFM & Public Finance Management \\
\hline PLWA & Persons living with AIDS \\
\hline PMTCT & Prevention of Mother-To-Child Transmission (of HIV) \\
\hline PPA & Participatory Poverty Assessment \\
\hline PPMER & $\begin{array}{l}\text { Projet de Promotion des Petites et Moyennes Entreprises Rurales (Project for } \\
\text { the promotion of Small \& Medium Sized Rural Businesses) }\end{array}$ \\
\hline PRS APR & Poverty Reduction Strategy Annual Progress Report \\
\hline PRSC & Poverty Reduction Support Credit \\
\hline PRSP & Poverty Reduction Strategy Paper \\
\hline PSIA & Poverty \& Social Impact Analysis \\
\hline QUIBB & $\begin{array}{l}\text { Enquete sur les Indicateurs de base du bien-etre (Basic Well being Indicators } \\
\text { Survey) }\end{array}$ \\
\hline RALGA & Rwandese Association of Local Government Authorities \\
\hline $\mathrm{RDF}$ & Rwandan Defense Forces \\
\hline RDRC & Rwanda Demobilisation \& Reintegration Commission \\
\hline RES & Rural Economy Strategy \\
\hline RNIS & Rwandan National Institute for Statistics \\
\hline ROSC & Report on the Observance of Standards and Codes \\
\hline RRA & Rwanda Revenue Authority \\
\hline SFAR & Student Financing Agency for Rwanda \\
\hline SIBET & $\begin{array}{l}\text { Système Informatique du Budget de l'Etat (Information System for the State } \\
\text { Budget) }\end{array}$ \\
\hline SIDA & Swedish International Cooperation Development Agency \\
\hline SPPMU & Strategic Planning \& Poverty Monitoring Unit \\
\hline STA & Single Treasury Account \\
\hline SWAP & Sector Wide APproach \\
\hline TA & Technical Assistance \\
\hline $\mathrm{TBC}$ & Tuberculosis \\
\hline TDM & Teacher Development \& Management \\
\hline UBPR & Union des Banques Populaires Rwandais (Rwanda Union of Popular Banks) \\
\hline UNDP & United Nations Development Programme \\
\hline UPE & Universal Primary Education \\
\hline VAT & Value Added Tax \\
\hline VCT & Voluntary Counselling and Testing \\
\hline VSAT & Very Small Aperture Terminal Satellite \\
\hline VSW & Vulnerability Support Window \\
\hline WB & World Bank \\
\hline
\end{tabular}




\section{Introduction}

Rwanda's PRSP was finalised and endorsed by all internal and external stakeholders in June 2002. Annual Progress Reports (APR) were published in 2003 and 2004, while the current report looks at progress made in 2004 and early 2005.

The timing of the APR is strategically positioned to influence the debate on resource allocation. In March and April of each year, joint sector reviews are held in all sectors, to look back critically at performance over the last year and identify the priorities and strategies for the years ahead. The reviews produced in this context are summarised in the APR. While the different ministries proceed to produce strategic issues papers to support their respective budget requests for the coming year, the APR report contributes to a global assessment of what overall government priorities should be set for the coming year in light of progress and arising constraints in the various sectors. To this end, it is crucial that the APR process is concluded in June / July of each year.

This year the report contains more information than ever before, and provides a more comprehensive picture of progress. One of the innovations in the production of this year's report was the requirement for sectors to provide a table with clear key objectives and associated performance indicators. This should not only provide a clearer picture of real progress achieved, but also help analyze what value for money government is getting in the various sectors. The result of this attempt is discussed in the M\&E chapter, which has been moved to the end of the report.

The APR process is intended to be participatory, drawing from joint reviews that are carried out in the various sectors. Unfortunately, joint reviews were not held in every sector this year, a problem which the Strategic Planning Unit in MINECOFIN, lead ministries and lead donors must work to resolve in future years (for example through announcing the formal launch of the APR process in the Development Partners' Coordination Group). Further consultations were held with partners following the distribution of a zero draft of the report. The Strategic Planning Unit has edited the whole document to ensure harmony and avoid duplication.

In future years it will be important to reflect progress achieved at decentralized levels more comprehensively. At the moment the joint sector reviews may miss out important progress in this area: rural roads, for example, despite featuring prominently in realising objectives for rural development, agriculture, and private sector development, are not covered in this report. To address this issue, it is the intention that in future years the joint sector reviews will be preceded by reviews at district and province levels. Further progress on the overall comprehensive M\&E framework should also help in this respect.

This third APR largely follows the same structure as the previous APR, starting with an analytical overview and then chapters setting out the macroeconomic context and progress in public financial management. Sectoral chapters then follow, with cross-cutting issues being dealt with in individual sections (placed where most relevant) which draw on reports from all sectors as well as by the institutions with special responsibility for those issues. Monitoring and evaluation is now covered at the end of the report. The policy matrix, looking forward to key 
actions in every sector over $2005-2007$ is attached as an annex, but can be read alongside the relevant chapters in the report. 


\section{Executive Summary and Analytical Overview}

\section{Macroeconomics and Public Finance}

The performance of the Rwandan economy improved in 2004. GDP growth increased from $0.9 \%$ to $4.2 \%$, exports strengthened, while fiscal and monetary policy targets were met. However, the economy faced two significant hurdles. First, another year of bad rains resulted in a poor harvest, high food imports and an inflationary push from rising food prices. Second, the impacts of the domestic electricity shortage and rising fuel costs also drove high inflation. Overall growth in 2004 was driven by a buoyant construction sector and rapidly developing tourism, travel and communications sectors. However, due to unfavourable climatic conditions, there was no growth in agricultural production.

Government of Rwanda continued the implementation of its widespread programme of reform of the national public finance management system. Among one of the key issues, the new Organic Budget Law is expected to be fully adopted soon and will provide a consolidation of all previous laws governing the public finance management system in Rwanda. However, further integration of the recurrent and development budgets and improved sectoral and aggregate reporting on budget allocations and executions remain a high priority.

Progress on aid coordination and harmonisation was consolidated during 2004 by putting in place some new structures, such as the External Finance Unit in MINECOFIN and the DPCG secretariat.

\section{Agricultural transformation and rural development}

In 2004 GoR focused on the formulation of the Agricultural policy and its operationalisation through the Strategic Plan for Agricultural Transformation (PSTA), which was finalised in October. Institutional reforms and restructuring have formally led to the creation of Rwanda Agricultural Development Authority (RADA), Rwanda Animal Resources Development Authority (RARDA), ISAR, and Quality Control Stands Agency (QCAS). In 2004, coffee and tea comprised $58 \%$ of total goods exported. Coffee in particular, saw a large production increase to 29,000 tonnes or $98.6 \%$ on 2003 figures, generating $\$ 32$ million in export receipts (i.e. $36 \%$ of total exports). Amongst the domestic food crops, rice production increased by $64 \%$.

Performance of the agriculture sector was adversely affected by poor rainfall. Consequently, the sector saw virtually no growth in 2004. Despite some increases in export crops (e.g. coffee), the production of basic food crops, and hence food security, was most affected. Major crops contained in the consumption basket decreased with the exception of Irish potatoes. Implementation of the PSTA implies reinforcement of human resources and extension services.

There has been an overall improvement in the recurrent budget execution from MINAGRI, but execution in some important programmes, such as crop production, veterinary services, etc. needs special attention. 
Whereas reporting on agriculture is much improved compared to previous years, the rural development cluster is so far not functioning and no comprehensive reporting on rural sector development is possible.

\section{Human resource development and improving the quality of life}

Significant progress has been achieved in the area of Human Resources in the health sector, with all indicators beating their targets. However, further needs remain substantial, and recent efforts to set up a basket funding arrangement for human resource development are very welcome, especially for those donors moving away from project support. Availability of drugs, vaccines and consumables improved somewhat during 2004, except for units of blood distributed, which saw a dramatic decline. Geographical and financial access to health services also improved, with particularly the percentage of the population enrolled in mutuelle insurance schemes taking off.

The mutuelle scheme is highly appreciated at district level as it effectively increases access to basic health care services; this is a significant pro-poor achievement and the initiative should therefore be strengthened further. Moreover, low quality of health services at health centres is perceived as a major obstacle to effective service delivery, and additional funds should be allocated to provide equipment and train health personnel.

Budget execution for the health sector in 2004 has been good, with around 90 per cent of budgeted funds disbursed. However, at least for the recurrent budget, significant discrepancies exist between primary and specialist health care services. Aligning the health sector MTEF with the programme structure contained in the strategic plan would significantly strengthen the link between planning and budgeting and would simplify policy review. It also appears that more ambitious policy targets need to be set, as many targets for 2004 appear to be even below realisations for 2003 .

Investing in education, particularly basic education is key to the long term development of Rwanda and remains of highest priority to the government. The sector has been making steady progress in increasing enrolment and completion rates in recent years, though further progress is required to lower repetition and drop out rates. Net enrolment rates at primary level now stand consistently above 90 per cent as a result of the new policy on fee-free primary education and an increased capitation grant, implying that even the poorest households are able to send their children to school.

Government has decided that the first 3 years of secondary education be part of basic education and a "Nine Year Basic Education for All" framework is now in place, aiming to increase P6 completion rate to above $75 \%$ by 2015 and increase the transition rate from grade 6 to grade 7 to above $75 \%$. Whilst access to education at the primary and secondary levels appears to be even between girls and boys, differences in equity in terms of school-type remain with a higher proportion of boys attending better resourced public secondary schools. Significant gaps also still exist at the tertiary level.

Budget execution for the education sector has been high for the recurrent budget, with spending on tertiary education exceeding the budget by around 20 per cent. Execution of the development budget appears lower, but there is evidence of reported figures not actually capturing all donor disbursements. Looking forward, the 9 year basic education framework will put substantial pressure on the education infrastructure in terms of number of classrooms, teachers, and books 
that are required, and therefore requires additional funding in future years. Further increasing the capitation grant would be a significant pro-poor policy measure that not only consolidates progress on access but also addresses quality.

A new Water and Sanitation policy was adopted in 2004 which envisages a dynamic approach with responsibilities delegated to communities and districts. It restricts the focus of the central government to planning, regulation, promotion, monitoring and oversight. Decision making is decentralized with active community participation at all stages of the project cycle to ensure a demand driven approach.

Accordingly, a number of promotion activities were carried out in 2004 to encourage private sector participation in the water sector, and a diagnostic study was undertaken on water management. A large number of projects have been completed or continued ongoing work to construct, rehabilitate, or extend water infrastructure. Infrastructures put in place during the last few years benefit an estimated half a million people in rural areas, thus increasing the overall access rate to potable water in rural areas to $45.75 \%$ in 2004 , up from $41 \%$ in 2001 . Budget execution has been fairly poor with a number of problems hampering a swift implementation of the projects that were included in the 2004 development budget.

MIFOTRA has made significant progress in reporting this year on Human Resources and Capacity Building, coordinating a well-presented and informative chapter. However, as they have pointed out, significant challenges remains to co-ordinate and harmonize the different interventions in this sector. Special attention is required in the future to strengthen analysis and evaluation of the sector as a whole.

The public service reform programme was implemented in all ministries, provinces and districts in the country focusing on efficiency, decentralization of services and accountability. The programme will be completed by the end of 2005. So far, 1,141 civil servants were retrenched, but many of them are benefiting from different programmes organized by MIFOTRA to allow them to get absorbed in the country's labour market. Those who remained in service are supposed to have continuous skills development programmes oriented to their job tasks. Starting with 2005, RIAM will train top managers and executive officers in the public service on all government policies, programmes and strategies for Vision 2020 and the PRSP for a common understanding and implementation of the country's development agenda. Moreover, the Human Resource and Institutional Development Agency (HIDA) was established end 2004 to coordinate and carry out oversight of the Multi-sector Capacity Building Programme in the country.

HIMO started providing alternative employment to the rural areas and in 200414,142 jobs were offered in the provinces of Gikongoro, Kigali Ngali and Umutara with average earnings of 400 frw per day.

\section{Economic infrastructure}

Efforts to improve the national road network have yielded significant results in recent years with a number of important national roads having been rehabilitated. However, it is currently somewhat difficult to interpret the presented information at a national level in terms of the state of the overall road network, general access to transport services and the cost of transportation. Efforts to strengthen the strategic planning process in MININFRA should therefore be accorded 
highest priority. As a related issue, maintenance of all newly constructed and rehabilitated roads will absorb increasing amounts of funds, which must be addressed through the Road Maintenance Fund.

Rural transport links continue to rate highly on district priority lists and are crucially important to increase access to markets and underpinning a more general national export promotion strategy. However, with the responsibility for rural roads having been decentralised, unfortunately no clear information currently exists on progress in this area.

Acute electricity shortages in 2004 marked the culmination of over 30 years of under investment in the energy sector. The implementation of the electricity Emergency Action Plan brought some relief in the form of thermal power, although the resulting high costs of electricity present a significant burden on consumers and businesses. Nevertheless, further progress is being realized in exploiting the methane gas from Lake Kivu, which should allow a massive expansion in the overall amount of electricity produced at reduced cost.

Substantial progress has been recorded during the past year in the area of ICT, even if imperfect and irregular. Although Rwanda's ICT sub-sector is embryonic and still accounting for a relatively small share of the economy's output, there is evidence of rapid growth. Government's push for ICT development resulted in the connection of 27 government buildings in Kigali to the fibre optic network backbone. The backbone is currently being expanded to other towns. Other highlights are the privatisation of Rwandatel and its granting of a $2^{\text {nd }}$ national mobile network license and a massive rise in the number of mobile phone subscribers. In the rural areas, an additional 44 VSATs have been installed.

\section{Good Governance}

In 2004, MINALOC operationalised the second phase of the 'Rwanda five-year decentralisation implementation programme', which seeks to ensure the participation of the whole population in decision making processes and planning and to facilitate a better allocation of resources in favour of local government. However, CDF disbursement to the districts, one of the main sources of financing, was extremely disappointing, while rural districts often do not have a sufficient local economic base to generate their own revenues to cover administrative overheads.

A steady improvement in the security situation in recent years has visibly contributed to the growth of commercial activities, a return of many refugees and the capture or surrender of Interahamwe/Ex-Far militants. Rwanda has also been able to allocate defence resources to contribute to international peace keeping efforts in Darfur. Internal security has seen dramatic progress in 2004. Reported crimes fell by $30 \%$ from 2003 to 2004, as a result of sensitization of communities on security and provision of crime information, as well as strengthened capacity of the police with officers trained for community policing. Road accidents have been reduced by $40 \%$ from 2003-2004 due to an increase in police in the traffic department, resulting in more highway vehicle traffic patrols and highway check points.

The National Unity and Reconciliation Commission elaborated a new action plan in July 2004. More than 720 voluntary community animators around the country were trained to help the NURC promote reconciliation at local level, and a national summit was held in May, bringing together over 1000 Rwandans to review progress in reconciliation and debate the way forward. A similar summit was organised for children, and many other sensitization activities carried out. 
The Gacaca courts were rolled out across all districts in Rwanda during 2004, involving nearly all the population in this process of local justice, helping to speed-up the processing of cases and promote reconciliation based on truthful confession of genocide related crimes committed during 1994.

On transparency and accountability, significant progress was made during 2004 with the operationalisation of the Office of the Ombudsman

Overall, progress in good governance has been impressive. However, improving the performance of the CDF is of utmost importance.

\section{Commercial Sector Development}

Rwanda is in the final stages of the Integrated Framework process which will produce detailed policy recommendations for the way forward. Also, over the last year Rwanda has become an increasingly active member of COMESA and has applied for membership of the EAC. These developments, alongside the Economic Partnership Agreement (EPA) negotiations, provide the framework for Rwanda's commercial sector development over the next few years.

The Integrated Framework process has lead to a holistic strategy to move subsistence farmers into commercial crops or non-farm activities. Integrating this strategy across the different sectors is of the utmost importance over the near future.

\section{Social Protection, Gender, and Youth}

Some progress but largely good intentions can be noted in the areas of social protection - most notably through the elaboration of the social protection policy and the introduction of the above mentioned mutuelle health insurance scheme - and gender. Reporting on the cross-cutting issue of youth was disappointing, with MIGESPOC failing to submit a progress report. 


\section{Macroeconomic Overview}

\subsection{Overall Macroeconomic Performance}

The performance of the Rwandan economy improved in 2004 ${ }^{1}$. GDP growth increased from $0.9 \%$ to $4.2 \%$, exports strengthened, while fiscal and monetary policy targets were met. However, the economy faced two significant hurdles. First, another year of bad rains resulted in a poor harvest, high food imports and an inflationary push from rising food prices. Second, the impacts of the domestic electricity shortage and rising fuel costs also drove high inflation. Inflation was never less than $10 \%$ over 2004 , and was at $13.1 \%$ at the end of the year. This occurred despite the pursuit of prudent monetary policy, with no growth in money supply between December 2003 and September 2004.

2004 also witnessed a number of structural reforms, with the objective of improving the foundations for more robust economic growth going forward. These included a strengthening of the financial sector, streamlining of the tax system, and reforms to increase transparency and accountability in the public financial system.

Thanks to a $55 \%$ increase in export receipts and $43 \%$ growth in revenues from tourism ${ }^{2}$, both the trade balance and the current account balance improved as a percentage of GDP in 2004. The coffee crop was particularly solid, with exports doubling in value terms.

The negative effects of the climatic shock and energy crisis persisted in the economy during the first quarter of 2005, with agriculture and manufacturing weak. The services sector together with construction and mining, however, remained strong, while monetary and fiscal targets were reached. In April 2005, Rwanda reached the HIPC completion point. This will allow Rwanda to save approximately US\$48 million each year for the next ten years on debt service.

Though the next country-wide household survey will be carried out only towards the end of this year and will enable a fuller analysis of how poverty has changed since 2001, the following paragraphs consider the likely impact on poverty of recent developments in the economy.

\subsection{The Real Sector}

Overall growth in 2004 was driven by a buoyant construction sector and rapidly developing tourism, travel and communications sectors. However, due to unfavourable climatic conditions, there was no growth in agricultural production in 2004. See table 3.1.

\subsubsection{Agriculture}

For the second year running, the food crop declined. Almost $90 \%$ of the population depend on the land for their livelihoods, so this has disturbing implications for poverty. The $17 \%$ decline in the production of beans, the major protein source for many households, is a particular cause for concern.

\footnotetext{
${ }^{1}$ For further details of economic developments in 2004, please see the MINECOFIN Annual Economic Report, available on the website www.minecofin.gov.rw.

${ }^{2}$ Tourism receipts are classified under non factor services; they rose from $\$ 30 \mathrm{~m}$ in 2003 to $\$ 43.5 \mathrm{~m}$ in 2004 .
} 
Table 3.1 Performance of the real sector

\begin{tabular}{|l|l|l|l|l|l|}
\hline GDP Rwf billion & 2002 & 2003 & 2004 & \\
\hline Agriculture & & & Growth & actual & growth \\
\hline Of which: Food crop & 299.1 & 286.9 & $-4.1 \%$ & 289.36 & $0.8 \%$ \\
\hline Industry & 255.9 & 244.4 & $-4.5 \%$ & 241.8 & $-1.1 \%$ \\
\hline Services & 112.5 & 120.5 & $7.1 \%$ & 128.8 & $6.9 \%$ \\
\hline & 224.1 & 234.7 & $4.7 \%$ & 253.2 & $7.9 \%$ \\
\hline GDP & & & & & \\
\hline
\end{tabular}

The volume of food imports increased by $22 \%$ (or around 17 thousand tonnes) over the year. In comparison, the total volume of food production in Rwanda was 6,817,770 tonnes in 2003, which fell to 6,751,315 tonnes in 2004, a reduction of over 66 thousand tonnes.

In the absence of detailed data about the distribution of this aggregate food availability decline, it would be premature to draw strong conclusions about the poverty implications, but directionally the indications are clearly negative; poor food harvests will directly affect the very poorest marginal subsistence farmers.

The price of the basket of food in the CPI increased by $16 \%$ over 2004 . Within this, bread and cereal prices increased by $26 \%$, while the price of beans increased by $19 \%$.

As food items constitute a larger proportion of the consumption basket of the poor compared to the non-poor, we could conclude that this has had a disproportionately negative effect on the poor, in particular upon those who are not themselves engaged in food production. However, we must recall that the price of food is only relevant to those who are engaged in markets; for households operating in the non-monetised economy, food price inflation is only relevant to the extent that there are secondary effects on the barter economy, an area that is not well understood.

The government is currently investing heavily in improving farmers' productivity with a range of initiatives to allow to farmers increase the application of fertilizer and introduce better seed varieties.

The production of all animal products increased over 2004, with the exception of fish. There was, for example, an $8 \%$ increase in the volume of milk and a $16.1 \%$ increase in the production of meat. However, data from MINAGRI warn that the requirements of the population are far from met by current production levels - shown in Figure 3.1 below. 


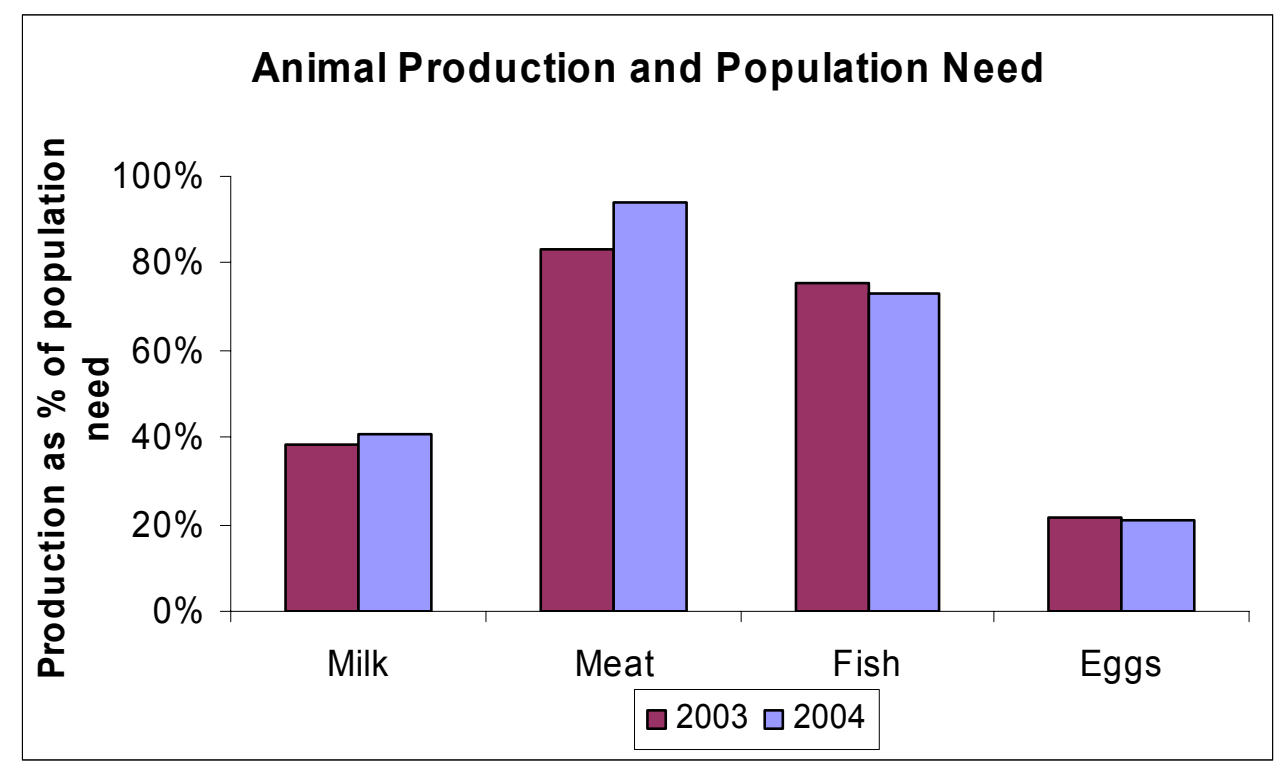

Source: 2004 - MINAGRI; 2003 - MINECOFIN estimate

\subsubsection{Industry}

Mining and quarrying activities expanded by an estimated 55 per cent over 2004, largely boosted by increased cassiterite tin production. Value added in this sector increased from RWF $89 \mathrm{bn}$ in 2003 to RWF $100 \mathrm{bn}$ in 2004 . The mining and quarrying sector is estimated to directly employ around 50,000 people in Rwanda.

Growth in the industrial sector reached nearly $7 \%$ over 2004 , despite the negative effects of the double energy crisis (rising fuel costs and electricity shortage) and new competitive pressures arising from the COMESA free trade area entry in Jan 2004. The price of the category "housing, water, electricity, gas and other fuels" in the CPI grew by $18.2 \%$ over 2004 , with the price of solid fuel rising by $35 \%$. The price of electricity was held constant over 2004, but was almost doubled between December 2004 and January 2005. It is important to remember, however, that the very poorest would not suffer directly from this increase in the price of electricity.

The construction sector and its supporting industries, such as furniture and chemical manufacturers, were the lead industries in 2004, with the building of private dwellings and roads being key. In addition, many large construction projects such as the BDCI building, and three new hotels reached completion in 2004.

Industrial production overall was rather mixed, as demonstrated in Figure 3.2 below. 


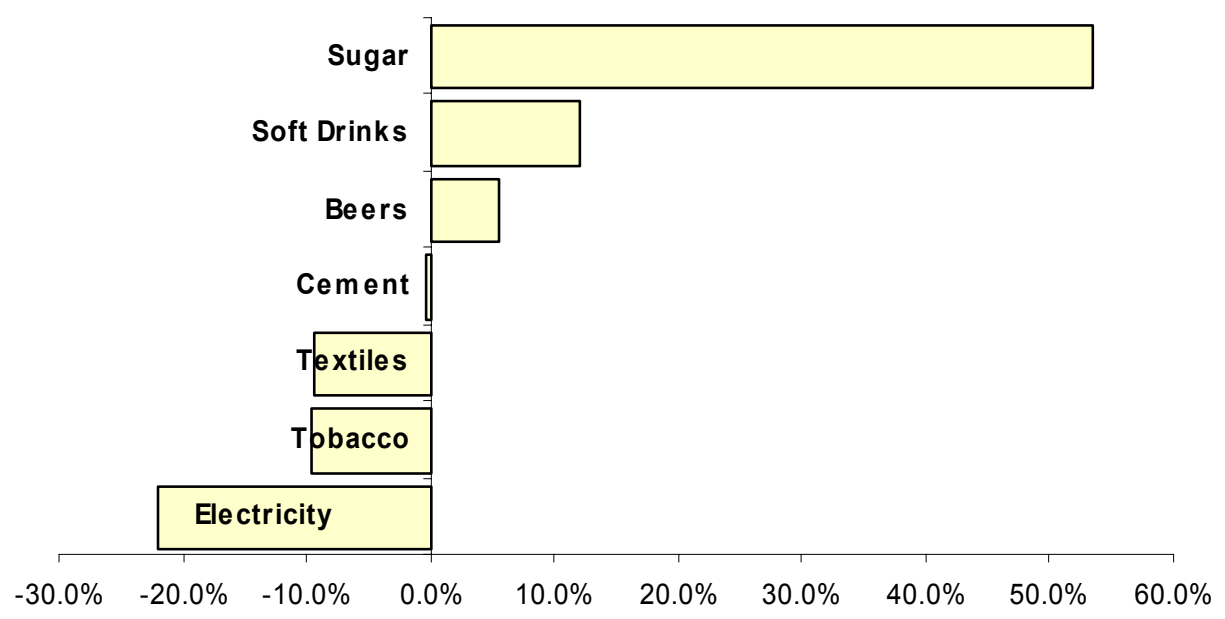

\subsubsection{Services}

Services constituted the strongest performing sector in 2004, with growth of almost $8 \%$. Available indicators suggest that growth was particularly strong in the tourism, transport and communications sectors. Turnover declared at the Rwanda Revenue Authority increased for all service sector groups ${ }^{3}$ (see Table 3.2, below). Statistics from the ORTPN show that total number of visitors to national parks increased by $63 \%$ in 2004 with tourist numbers rising from around 15,000 to almost 26,900 from 2003-04 (including 35.1\% more visits from foreigners), while Balance of Payments data show revenue from tourism increasing by $45 \%$. Revenues from tourism in 2003 are estimated to have been US\$30.1 million, climbing to US\$43.5 million in 2004. One survey carried out for ORPTN suggested that for every tourist entering Rwanda, an extra 7 jobs were created (directly and indirectly).

\section{5}

Real sector performance during the first quarter of 2005 followed a similar trajectory. Again, bad rains in the early season contributed to a meagre $2 \%$ growth in the food crop, while electricity shortages and rising energy costs hampered industry. As in 2004, however, the construction and services sectors remained healthy.

\footnotetext{
${ }^{3}$ Note that declared revenue can increase for a number of reasons: increased business, higher inflation, and the addition of new firms to the formal economy (tax register)
} 


\begin{tabular}{|lrrr|}
\hline Rwf billion & \multicolumn{1}{c}{$\mathbf{2 0 0 3}$} & \multicolumn{1}{c}{ 2004 } & \% change \\
\hline Banking and Insurance & 22.03 & 25.39 & $15.3 \%$ \\
Clearing Agency & 1.10 & 1.43 & $29.2 \%$ \\
Consultancy and Advocate & 2.01 & 2.08 & $3.7 \%$ \\
Electronic Service & 3.08 & 3.49 & $13.1 \%$ \\
Garage & 1.99 & 2.39 & $20.0 \%$ \\
General Commerce & 93.43 & 105.62 & $13.0 \%$ \\
Hotel and Snack Bar & 8.06 & 8.60 & $6.7 \%$ \\
Other Services & 11.33 & 13.39 & $18.2 \%$ \\
Pharmacy & 3.64 & 4.84 & $33.2 \%$ \\
Post and Telecoms & 21.81 & 26.00 & $19.2 \%$ \\
Premises Renting & 0.58 & 0.73 & $26.5 \%$ \\
Printary, Stationary and Book Shop & 3.82 & 4.17 & $9.2 \%$ \\
Transport & 6.46 & 7.31 & $13.1 \%$ \\
\hline Total & 179.33 & 205.43 & $13.1 \%$ \\
\hline
\end{tabular}

Source: RRA

\subsection{The External Sector}

The trade balance and the current account balance both improved as a percentage of GDP in 2004, due to strong growth in exports and tourism receipts as well as improved donor disbursement of grants.

\subsubsection{Exports}

Export performance was outstanding in 2004, climbing from $\$ 63 \mathrm{~m}$ in 2003 to $\$ 98 \mathrm{~m}$ in 2004 , driven primarily by coffee, cassiterite tin and coltan. Exports of coffee doubled in value terms thanks mainly to an $82 \%$ increase in the volumes, while exports of fully washed coffee, which attract a price premium, also grew from 270 tonnes in 2003 to 700 tonnes in 2004, thanks largely to a doubling (from 10 to 20 ) in the number of operational washing stations. This would have benefited coffee farmers, who constitute around 10 percent of rural households - about 400,000 people. However, given that on average coffee producers spend 40 percent of their income on food products, such benefits would have been partially diluted by the high food price inflation.

The volume of cassiterite tin exported more than doubled in response to a $45 \%$ increase in price. Similarly, coltan also saw prices rise and volumes increase in response. Mining products constituted around 32\% of export during 2004. Exports of tea remained almost flat in 2004 in most provinces.

Note that last year's strong export performance was based on four commodities whose prices have historically been very volatile. Future export performance of these commodities remains highly vulnerable to exogenous price movements that Rwanda is unable to influence. 


\subsubsection{Imports}

The value of imports of capital goods and energy grew, due to the electricity shortage (including the import of generators and fuel) and also in response to the rapid increase in oil prices. There were reductions in imports of most intermediate goods, due to a lacklustre manufacturing sector and low availability of finance in agriculture; however, 2004 saw a 32\% growth in imports of construction material. As noted above, there was substantial growth in food imports; $53 \%$ in value terms.

\section{5}

The trade balance was in deficit at $\$ 74.3 \mathrm{~m}$ at the end of the first quarter in 2005 , a substantial deterioration when compared with the $\$ 39.3 \mathrm{~m}$ deficit for the corresponding period last year. This followed a $65 \%$ increase in the value of imports along with only $7.6 \%$ growth in the value of exports. Imports of intermediate goods rose by $93 \%$ in value terms, driven mainly by increased imports of construction goods, while the value of imported consumption goods grew by $52 \%$. Conversely, the first quarter of this year saw volume and value reductions in both coffee and tea exports.

\subsubsection{Capital Account and Financial Operations}

The balance of these accounts increased in 2004 largely due to enlarged loan financing for both the development budget and the recurrent budget, which included a large loan from the World Bank to assist with implementing the Poverty Reduction Strategy.

Within the Financial Operations account, foreign direct investment grew from $\$ 4.66 \mathrm{~m}$ in 2003 to $\$ 7.66$ million in 2004 . This growth was due to privatization of two banks, BCR and BACAR.

\subsection{Public Finance}

The performance of public finances was strong in 2004. The ratio of domestic revenue to GDP increased (14.2\% compared to $13.5 \%$ in 2003 , against $12.1 \%$ and $11.2 \%$ in 2002 and 2001 respectively) and expenditure was lower than programmed, resulting in the overall deficit before grants also being lower than programmed. Domestic tax and non-tax revenue increased by Rwf $20 \mathrm{bn}$ and Rwf $7 \mathrm{bn}$ respectively. Tax revenue was primarily driven by improvements in PAYE collection and increased VAT revenues owing to inflation. Non-tax revenue benefited from the sale of government houses, the strategic petroleum stocks and National Bank dividends and demonetisation of some Rwandan francs.

Budget support grants funded $49 \%$ of recurrent spending in 2004 compared with $31 \%$ in 2003 , while project grants funded 39\% of capital expenditure compared with $43 \%$ in 2003 . 


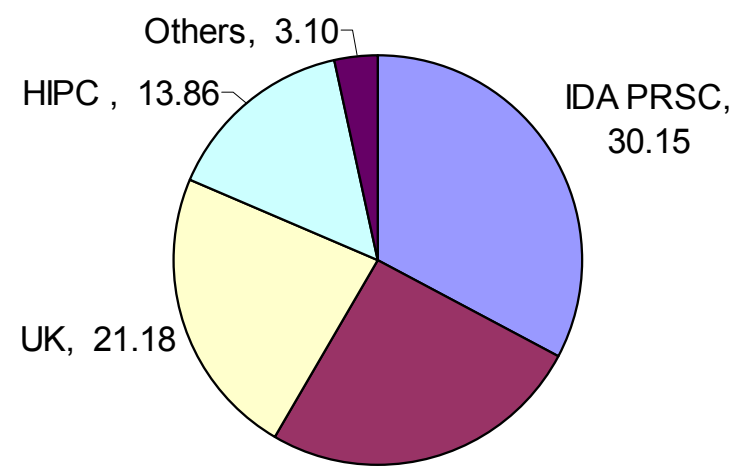

EU, 23.41

Government expenditure reached Rwf 275.36billion in 2004, 26\% higher than in 2003. Allocations to the domestically financed capital budget grew by Rwf 14.2billion, to fund agricultural productivity programmes and the Ministry of Defence, Rwanda Revenue Authority, and Office of Auditor General buildings, as well as additional expenditure on emergency energy items.

Actual expenditure was Rwf 11.05bn below that presented in the revised budget in June, primarily due to delays in the demobilization programme.

\section{5}

The first quarter saw an exceptional performance of domestic tax revenue, which was $18.4 \%$ higher than in the same period in 2004, exceeding its PRGF programme target by $9.8 \%$. This was in part due to improved tax enforcement and the collection of tax arrears, as well as improved efficiency at RRA. Non-tax revenue was just over $2 \%$ higher than in 2004, underpinned by the sale of government cars and of former police land.

Total general budget support totalled $\$ 40.38 \mathrm{~m}$ during the first quarter of 2005 . In addition there was $\$ 7.71 \mathrm{~m}$ given to the Demobilisation Commission: $\$ 0.67$ million from the UK and $\$ 7.04$ million from the World Bank.

Government expenditure in the first quarter of 2005 reached almost RWF 44.5 million, $14 \%$ up from the corresponding period in 2004 .

\subsection{The Monetary Sector}

High inflation in 2004 was essentially due to external shocks (high energy prices, and increased food prices brought about by poor weather and consequently low harvests), as opposed to expansionary monetary policy. Key government targets in the monetary sector were met, with reserve money growth and net credit to government below ceilings, and net foreign assets of BNR consistently above target. 
Broad Money grew by $10.4 \%$ over 2004; relatively modest growth compared with the $16.4 \%$ growth over 2003, largely due to a decline in government borrowing from the banking system. In addition, credit to the economy grew at only $10.0 \%$, compared with $15.3 \%$ in 2003 ; growth in credit to the private sector was slow for much of the year, which may be attributable to the continued cautious approach to credit on the part of the commercial banks, and also to the restructuring plans currently in place.

Figure 3.4 below demonstrates a familiar story in the pattern of sectoral distribution of credit; a key problem remains that agriculture still receives only a very small share of credit, whilst constituting the largest single sector of the economy.

\section{Figure 3.4 The Sectoral Share of Credit to the Economy}

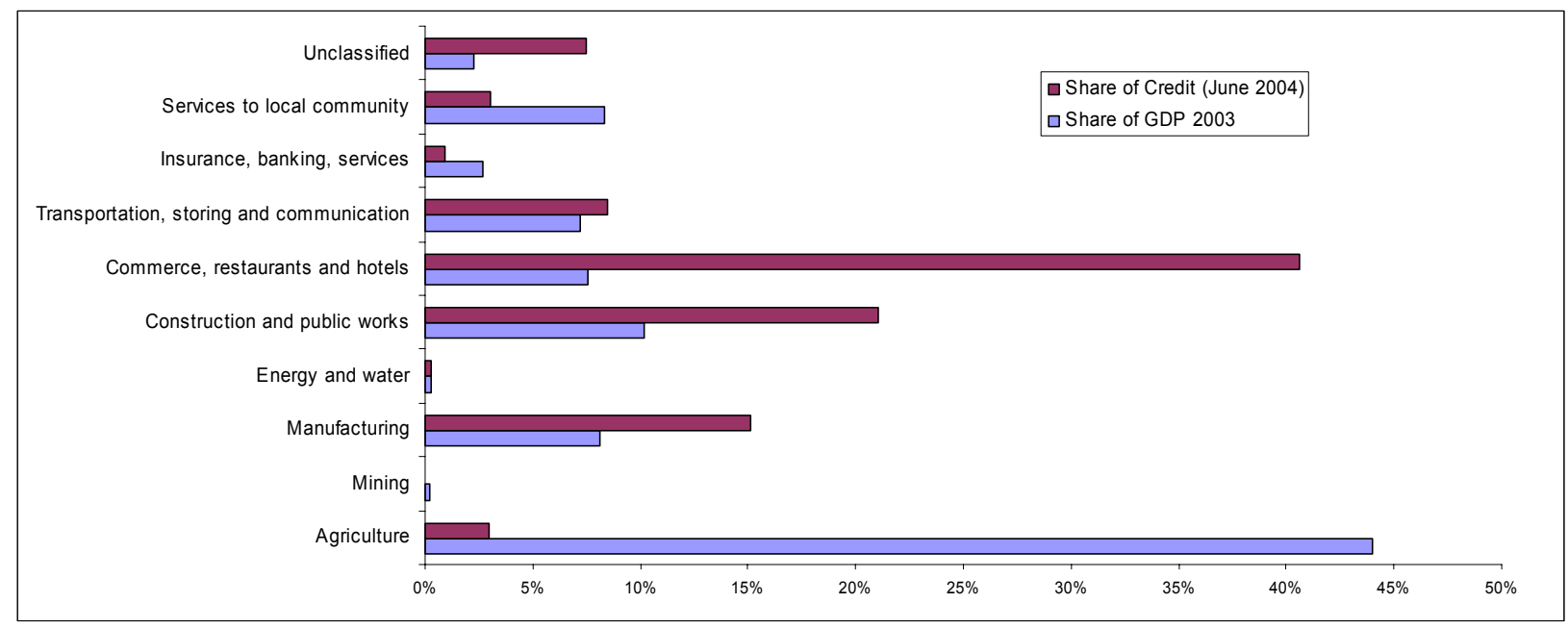

2004 saw stability in interest rates, with the discount rate constant at $14.5 \%$ throughout the year, and the rate of return on treasury bills fluctuating between 12.2 and $12.9 \%$.

Thanks to stronger export earnings, a decline in the money supply during the first half of 2004, and a weak dollar, the Rwandan franc reversed its depreciation and began to appreciate slightly against the dollar in 2004, appreciating by about $3 \%$ over the year as a whole.

\section{5}

Broad money increased by $1.9 \%$ in the first quarter of 2005 ; this is within what would be required to meet the target of $10.3 \%$ money supply growth for 2005 as a whole, a target set with the objective of allowing for a $4 \%$ level of inflation, and $6 \%$ growth in real terms. Given that inflation is currently at around $13 \%$, primarily due to growth in food and energy prices, there remains controversy over the extent to which monetary policy should accommodate these exogenous price rises.

\section{Treasury Bonds}

Treasury Bonds are used both as a tool of monetary policy and to raise funds for government spending. While the substantial donor inflows occurring at the beginning of the year reduced the need for government to issue treasury bills for financing purposes, they also led to excess liquidity in the banking sector. Overall there was a substantial increase of $32 \%$ in the value of 
Treasury Bills issued in the first quarter of 2005 compared to the quarterly average issued over 2004.

Table 3.3 Issuance of treasury bills and deposit auctions

\begin{tabular}{|c|r|r|r|}
\hline TBs, RwF Millions & $\begin{array}{r}\text { 2004 Quarterly } \\
\text { Average }\end{array}$ & 1 $^{\text {st }}$ Quarter 2005 & Percentage change \\
\hline Total TBs issued & 34.83 & 39.04 & $32 \%$ \\
\hline For Mon Pol & 4.55 & 17.56 & $286.0 \%$ \\
\hline For Gvt financing & 30.28 & 21.48 & $(29.1 \%)$ \\
\hline Deposit Auctions & 40.39 & 122.1 & $197.4 \%$ \\
\hline
\end{tabular}

The mean rate of interest on TBs in the first quarter of 2005 was $6.6 \%$. The impact of these developments upon the profitability of BNR should be carefully monitored.

\subsection{Medium term macroeconomic framework}

The medium term macroeconomic framework is based on a number of basic assumptions summarized in Table 3.4. Real GDP growth is assumed to pick up slightly to an estimated 5 per cent during 2005 and to 6 per cent in 2006. From 2007 onwards, a growth rate of 6.5 per cent is assumed. Underlying these assumptions is the expectation that public investments in a number of sectors will start having an impact. In the energy sector, the methane gas project should alleviate overall supply constraints to the economy, while in the agricultural sector, increased use of fertiliser, improved seed varieties, and better management of marshlands is expected to provide an additional boost. Moreover, export promotion efforts, such as the construction of additional coffee washing stations and the privatisation of tea factories should start paying off, in addition to a general return on the recently concluded investments in transport infrastructure. Finally, tourism will continue to profit from a conducive environment.

Inflation will return to its target level of 4 per cent, driving a small depreciation of the nominal RWF/USD exchange rate of 1 per cent per year.

On the fiscal side, total revenues will stabilise at around 14 per cent of GDP following some one-off gains in 2005. Priority expenditures as a percentage of GDP are increased reflecting the savings realised from the HIPC initiative. The increase in net lending captures public investment in the methane gas project during 2006 (and to a lesser extent in 2007). Other than that, recurrent public spending is gradually declining to 16.9 per cent of GDP in 2008 .

Despite these prudent assumptions, a growing financing gap emerges over the medium term, based on current pledges of grants and concessional loans (in any case, given the country's precarious debt situation, the room to accept even concessional loan financing is severely limited). 
Table 3.4 Medium term macroeconomic framework 2005 - 2008

\begin{tabular}{|c|c|c|c|c|}
\hline & 2005 & 2006 & 2007 & 2008 \\
\hline \multicolumn{5}{|c|}{ (in billions RWF unless otherwise indicated) } \\
\hline Real GDP & 5.0 & 6.0 & 6.5 & 6.5 \\
\hline CPI National (\%) & 6.0 & 4.0 & 4.0 & 4.0 \\
\hline Nominal GDP & $1,166.2$ & $1,285.6$ & $1,424.0$ & $1,577.2$ \\
\hline Average exchange rate (RWF) & 566.9 & 589.6 & 613.2 & 637.7 \\
\hline \multicolumn{5}{|l|}{ Fiscal projections } \\
\hline Total Revenue & 169.6 & 180.0 & 199.0 & 221.0 \\
\hline as a $\%$ of GDP & 14.5 & 14.0 & 14.0 & 14.0 \\
\hline Total Expenditure and Net Lending & 338.5 & 386.3 & 399.8 & 434.2 \\
\hline as a $\%$ of GDP & 29.0 & 30.0 & 28.1 & 27.5 \\
\hline Recurrent Expenditure & 220.2 & 242.7 & 247.7 & 266.9 \\
\hline as a $\%$ of GDP & 18.9 & 18.9 & 17.4 & 16.9 \\
\hline Capital Expenditure + Net Lending & 118.3 & 143.6 & 152.1 & 167.3 \\
\hline as a $\%$ of GDP & 10.1 & 11.2 & 10.7 & 10.6 \\
\hline \multicolumn{5}{|l|}{ Primary Deficit } \\
\hline Excluding Exceptional expenditure & -38.0 & -59.0 & -59.3 & -65.3 \\
\hline as a $\%$ of GDP & -3.3 & -4.6 & -4.2 & -4.1 \\
\hline Including Exceptional expenditure & -66.9 & -92.1 & -80.4 & -82.2 \\
\hline as a $\%$ of GDP & -5.7 & -7.2 & -5.6 & -5.2 \\
\hline Overall Balance & & & & \\
\hline Including grants & -15.9 & -67.9 & -81.4 & -93.2 \\
\hline as a $\%$ of GDP & -1.4 & -5.3 & -5.7 & -5.9 \\
\hline Excluding grants & -168.9 & -206.7 & -200.8 & -213.2 \\
\hline as a $\%$ of GDP & -14.5 & -16.1 & -14.1 & -13.5 \\
\hline Domestic Fiscal Balance & -83.2 & -115.3 & -95.6 & -92.4 \\
\hline as a $\%$ of GDP & -7.1 & -9.0 & -6.7 & -5.9 \\
\hline Financing gap & - & 44.9 & 50.6 & 75.4 \\
\hline as a $\%$ of GDP & - & 3.5 & 3.6 & 4.8 \\
\hline Priority Expenditure & 119.3 & 151.4 & 179.5 & 220.2 \\
\hline as a $\%$ of GDP & 10.2 & 11.8 & 12.6 & 14.0 \\
\hline Wages and Salaries & 73.1 & 79.8 & 84.6 & 89.6 \\
\hline Civil service & 55 & 60.6 & 64.3 & 68.1 \\
\hline Transfers & 18.1 & 19.2 & 20.3 & 21.5 \\
\hline as a $\%$ of GDP & 6.3 & 6.2 & 5.9 & 5.7 \\
\hline as a $\%$ of domestic revenue & 43.1 & 44.3 & 42.5 & 40.5 \\
\hline
\end{tabular}




\section{Public Financial Management and Expenditures and Aid Harmonization}

The Government of Rwanda (GOR) has embarked on a widespread programme of reform of the national public finance management system, including an expansive decentralization process, in order to enhance the government's ability to use public expenditure to achieve its objectives for growth and poverty reduction set out in Vision 2020 and the PRSP.

New Government agencies such as the Rwanda Revenue Authority, National Tender Board and the Office of the Auditor General have been created in the last few years with sufficient autonomy to increase transparency and efficiency in their respective domains. In order to coordinate the different efforts in this area, the GOR, with support from some international donors has developed a Financial Accountability Review and Action Plan (FARAP). This document provides, not only a substantial review of the current PFM situation in Rwanda, but also a comprehensive roadmap of reforms to guide government policy in the coming years. In addition the Government has created a PFM Reform Steering Committee, with secretarial responsibility for the IFG, to coordinate the implementation of this action plan.

This chapter examines progress achieved and challenges experienced during 2004 in the key areas of Public Financial Management reforms, Fiscal Decentralisation and Budget Execution.

\subsection{Public Financial Management}

\subsubsection{Legal and Institutional Framework}

The New Organic Budget Law (OBL) has returned to parliament to incorporate recommendations made by the Senate. It is expected to be fully adopted soon and will provide a consolidation of all previous laws governing the public finance management system in Rwanda. The accompanying financial instructions to promote effective expenditure control were also issued during the last quarter of 2004, although they will need to be amended to reflect changes made to the Organic Budget Law during its deliberation in Parliament.

The independent Office of the Auditor General (OAG) has been created and works alongside the individual internal Auditors to ensure fiscal transparency and accountability. The OAG prepared its 2003 report and submitted it to Parliament, and government is taking action to address issues identified in previous reports.

Furthermore, to further reinforce financial management, the Office of the Accountant General was created. It is expected that this office will oversee and coordinate the current and future functions of the Treasury, Public Accounts and Internal Audit Units.

Thus far, the recurrent and development budgets have been prepared separately by the Budget department of MINECOFIN and CEPEX, respectively. This has caused significant weaknesses in the coordination of the two budgets leading to a misalignment between budgets and strategies. It is vital that the two budgets should be prepared and reviewed in a unitary manner to more easily align budget spending with the policy priorities both between and within sectors. To this end, the responsibility for the formulation of the PIP and the Development Budget have been 
transferred to the Budget Unit, while CEPEX has been restructured to make a smaller "Special Unit" dealing with project implementation now known as the National Project Bureau. At the same time, MINECOFIN has set up an External Finance Unit to coordinate all external assistance and to provide a focal point within the Ministry of Finance for donors.

\subsubsection{Budget and Expenditure Control}

The introduction of the MTEF represents the single most important improvement to Rwandan PFM in recent years. The government has managed to integrate the medium term expenditure projection with the actual allocation of resources in the annual state budget, representing the actual financial envelope available during the first year of the three-year MTEF. However, the enormous strides made with budget preparation have been somewhat hindered by the lack of many well-elaborated sector plans. Although the government currently maintains a functioning MTEF using annual Strategic Issues Papers, it will be impossible to reap all the enormous benefits that an MTEF could provide in the absence of the plans on which to base it. It is significant that the Ministries which have completed their plans have been the best performing ministries when it comes to budgeting.

In the coming year, the budget format should be improved through a revised economic and functional classification and a review of the programme and sub-programme structure for all ministries and agencies in line with their new organizational structures ("cadre organiques") and reflecting their key objectives as identified in the strategic plans. This will lead to diminishing the size of budgetary lines and correct misclassification and bad codification in the budget and at the same time facilitate the integration process.

\subsubsection{Treasury Reforms}

The Treasury Management Committee and the Cash Management units have been set up to improve treasury management and cash planning. Structures for cash planning have been drawn up to help improve predictability of cash flow, although assistance will be required to train line ministries and MINECOFIN staff in their application. Zero-balance accounts have been introduced that will pave the way for the implementation of the Single Treasury Account (STA) by the end of the year. After the introduction of the STA, agencies will be given warrant of funds (authorization to incur expenditure) and they will therefore not be expected to maintain separate accounts in the Central Bank. Government has converted all bank accounts of most ministries into zero-balance accounts, whereby the individual agency accounts become subaccounts of the Treasury account, with designated spending limits.

\subsubsection{Procurement}

Public procurement has been deconcentrated to budget agencies, with oversight by the National Tender Board (NTB). This system continued to work relatively well in 2003, although as the OAG synthesis audit report established, there are cases of agencies by-passing procurement regulations and the NTB. The National Procurement Code was adopted in the third quarter of 2004 and gives clear guidelines for all government tendering procedures. Due to the decentralization and deconcentration of the public tendering process, responsibility has been given to the Administrative and Financial Director (D.A.F) at both the central and provincial level for all tendering processes that do not exceed RwF 10 million for services and RwF 40 
million for public works and furniture. At the district level, the D.A.F. has been empowered to spend up to RwF 10 million for public works and RwF 5 million for services. Above these ceilings, all agencies must request N.T.B approval.

\subsubsection{Financial Management Information System}

The Government is currently piloting an upgraded Integrated Financial Management System, which will form a linked database between the Recurrent and Development budgets, the RRA, Public Debt (SIGAD software), MIFOTRA (SAP software for management of salaries), BNR (simultaneous update of payments on Budget Master/SIBET II), the National Tender Board, Districts and semi-autonomous agencies. The new network will be used in parallel for the preparation of the 2006 Budget and will be able to present pictures of actual payments in relation to budget appropriations and also to present annual accounts for the GoR. It is important to note that not all interfaces will come into force at the same time.

\subsubsection{Accounting and Auditing}

Rwanda has suffered from a dearth of public accountants. There have not only been difficulties with recruiting qualified accountants but there have also been retention problems. When one considers that there is also a widespread scarcity of accountants in the private sector, it becomes clear that it is extremely difficult for the government to attract qualified accountants into public service. Internal Audit also faces a shortfall in the number of qualified auditors. To this end, a needs-assessment and curriculum development study for developing the public accounting and auditing capacity in Rwanda was conducted during the first half of 2005. This study highlighted an estimated need for an additional 140 professional accountants and 45 auditors, while also pointing out a number of important training areas. There is also a need for a legal framework to be established to define clearly their realm of responsibility.

\subsubsection{Constraints}

Donor Resources account for over 50\% of the government's annual budget. Total Domestic Revenue alone would pay for only $75 \%$ percent of the fixed costs (e.g. legally mandated expenditures from Wages to Gacaca). This evidently leaves Rwanda in a precarious situation, should donor funds be delayed and therefore the predictability of these flows is crucial to the ability to plan, not only the MTEF, but the monthly Cash plan as well. Allied to this has been weak cash planning capacity within MINECOFIN and the line Ministries, which in turn, leads to a disincentive for considered budget preparation.

\subsubsection{Looking forward}

In an important step to coordinate and harmonise donor reviews, the Government of Rwanda and its partners have agreed on a joint monitoring approach. For 2005, the CFAA will result in the jointly agreed PFM report for the year, while in subsequent years the PEFA Strengthened Performance Measurement Framework will be adopted as the basis for annual monitoring. 


\subsection{Fiscal Decentralization}

\subsubsection{Local Government Financial Management Capacities}

All Districts/Towns have developed three to five year District Development Plans and are now successfully creating MTEF's, although of varying quality. There are still difficulties in submitting them to MINECOFIN, with only 77 out of 106 district MTEFs received for the 2005 budget.

During 2004, substantial training in financial management skills was provided to Local Government officials. This has included training on the Manual of Procedures, and also on financial reporting. However, low levels of education and literacy continue to slow down capacity building in Local Governments. District Councils in most Districts are still too weak to effectively analyse plans and budgets and to provide expenditure oversight. These weaknesses are further compounded by logistical difficulties; for example, normally insufficient copies are made of important Local Government financial documents.

Moving forward, a new cadre organique sets out minimum qualifications and salary structures for Local Government officials. Unfortunately, Districts/Towns are still a long way from possessing adequate financial and human resources to be able to fulfil this cadre organique.

\subsubsection{Local Government Revenue-Raising Capacities}

Most Districts (particularly rural ones) still have a very weak internal revenue collection base, with many unable to afford even to pay staff salaries. This said, some Local Governments have been more successful than others in generating own-revenues; in particular, significant success has been enjoyed by those Districts that have devolved some fiscal powers to the Sector level. For example, in Ngarama District, Katabagema Sector now collects revenue (especially property tax and fines) - $50 \%$ of which is handed to the District Treasury - and manages its own expenditure (it has developed a three-year action plan and MTEF budget). This structural set-up has resulted in improved revenue collection and more effective service delivery, and the District authorities are now planning to roll out this decentralisation arrangement to other Sectors.

A Study of Revenue Potential in all of Rwanda's 106 Districts/Towns has been carried out, but unfortunately no comprehensive synthesis of the findings has yet been produced.

\subsubsection{Inter-Governmental Transfer Systems}

More equitable transfer formulas have been introduced both for recurrent and development (CDF) budget transfers to Local Governments; criteria now taken into account include population size, area, presence of income-generating activities (markets, slaughter houses etc.), environmental conditions, infrastructure development activities, and level of poverty. In addition, CDF capacities are steadily being strengthened, with staff having undertaken training in community-driven development and social accountability, amongst other things. Moreover, a RNE-funded Institutional and Organisational Review of the CDF has enabled a three-year CDF Action Plan to be drawn up, which aims to increase the efficiency and accountability of the organisation, as well as to introduce budget support to Districts/Towns that meet basic requirements, while simultaneously targeting capacity building to Districts/Towns not yet 
meeting these requirements. A number of donors have expressed interest in providing budget support to Local Governments through the CDF.

However, despite all of the above achievements, Central Government grants (which form the main source of Local Government revenues) remain grossly inadequate and untimely. Indeed, both recurrent and development transfers are still a long way below their mandated levels of $5.3 \%$ and $10 \%$ of National Domestic Revenue respectively, and the frequent lateness of disbursements severely disrupts locally planned activities.

For 2003 and 2004 combined, the CDF received a total allocation of RWF 9.5 billion. However, up to the end of 2004, only RWF 4.6 billion had been committed while RWF 2.7 billion was actually disbursed. Poor disbursements by CDF reflect a number of problems. Firstly, capacity constraints at district level have lead to many project proposals of insufficient quality. To address this, CDF has made a provision of 5 per cent that districts can draw from to fund technical assistance to elaborate project proposals. Secondly, tendering procedure through NTB tended to delay project implementation. To this end, the threshold to involve NTB has been raised from RWF 3 million to 40 million. Thirdly, CDF has been reserving the full amount of commitments against the current year's budget, even though some disbursements would only take place in the next year.

The reduced allocation in the 2005 budget is explained by the funds of previous years which were not yet committed to the tune of RWF 4.9 bn. Overall, therefore, RWF 8.4 billion is available for 2005 .

\section{Table 4.1 Fiscal decentralisation (Rwf billion)}

\begin{tabular}{|c|c|c|c|c|c|}
\hline Rwf billion & $\begin{array}{l}2002 \\
\text { (Execution) }\end{array}$ & 2003 & 2004 & $\begin{array}{l}2004 \\
\text { (Execution) }\end{array}$ & \begin{tabular}{|l}
2005 \\
(Prelim.)
\end{tabular} \\
\hline Total Budget of Rwandan Ministries & 103.20 & 152.35 & 5134.00 & 122.13 & 135.50 \\
\hline Tot & 20.12 & 25.22 & 230.50 & 29.74 & 33.30 \\
\hline & 2.70 & 5.62 & 28.78 & 4.59 & 11.07 \\
\hline of which... Recurrent Transfer* & 1.70 & 1.53 & 3.28 & 2.53 & 4.07 \\
\hline $\mathrm{CDF}^{* *}$ & 1.00 & 4.09 & 5.50 & 2.06 & 3.50 \\
\hline
\end{tabular}

* Goods \& services for Districts $=3 \%$ of revenue in 2004 and 5.3\% revenue after 2005 .

** Gradually moving towards $10 \%$ of previous year's revenue. (4.5\% in 2004 and 5.16\% in 2005)

Source: MINECOFIN

\subsubsection{Monitoring and Evaluation of Fiscal and Financial Decentralisation}

Monitoring and evaluation of fiscal and financial decentralisation is improving, thanks in part to the establishment of District Tendering Committees, which procure decentralised goods, services and works (within set limits and guidelines provided by the NTB), and which present evaluation reports to both the NTB and the relevant Province administration. In addition, Local Governments have established function-specific committees at the administrative (Cell, Sector, District) and facility (health centres, schools, water supply) levels, with diverse stakeholder representation.

This said, there is still a long way to go. The role of Provinces vis-à-vis Districts (including coordination, supervision, technical support, monitoring and evaluation and approval of Local 
Government activities) is carried out only to a very limited extent, and logistical provisions for monitoring and evaluation remain inadequate; for example, auditors in rural areas often have no access to transport or computers. Furthermore, there is still no comprehensive and complete fiscal and financial decentralisation data set in MINALOC, although the World Bank has pledged to help set up a simple database in the near term.

\subsubsection{Overall Support to Five Year Decentralisation Implementation Programme (DIP)}

In addition to the numerous donor- and NGO-supported projects being undertaken at the District and grassroots levels (and the donor support to the CDF as mentioned above), many donors are supporting decentralisation at the central level, through the provision of institutional support to MINALOC, RALGA, the Provinces etc. USAID is just coming to the end of a period of support for the Local Government Finance Unit in MINALOC, and now SIDA and DFID are looking to possibly carry on this support, as well as potentially providing funds for fiscal and financial decentralisation more generally. Meanwhile, SIDA is also providing support to RALGA, and UNDP is funding the National Decentralisation Implementation Secretariat, which is the main co-ordinator and facilitator of the DIP implementation process. In addition, the RNE is supporting the Provinces to provide more technical assistance to the Districts, and is also carrying out an Institutional and Organisational Analysis of MINALOC; the World Bank is working on decentralised service delivery; and the Swiss are doing some work on the harmonisation of interventions.

\subsection{Budget Execution 2004}

Priority sectors are increasingly getting substantial funds, amounting to 7.1 per cent of GDP in 2004 compared to 7 per cent in the previous year. Priority spending accounted for 49 per cent of the total recurrent budget excluding interest payments in 2004. Education (56.5\%) and Health $(14.5 \%)$ made up the bulk of priority spending. Non-priority spending is dominated by Defence $(37 \%)$.

Budget allocation as well as execution figures are given in Table 4.2. Administrative services excluding debt related transactions declined substantially, while allocated expenditures on all other sectors remained constant or even increased as a share of GDP. The budget was executed at 87 per cent for the recurrent budget compared to 93.4 per cent for the development budget. Shortfalls in the execution of the recurrent budget can largely be attributed to public debt related transactions and lower than programmed disbursements under the demobilisation programme (shortfall of RWF 9.2 billion).

Execution rates for the development budget vary enormously as shown in Table 4.3. The overall development budget amounted to RWF 87.2 billion, whereas RWF 81.5 bn was executed. The overall execution rate was significantly boosted by RWF 19.6 billion spending on emergency measures to address the electricity crisis, such as the importation of generators, fuel, and other associated costs. Other than that, with the exception of the transport \& communication and industry \& commerce sectors, execution rates appear poor across board. However, the development budget database continues to be plagued with incomplete reporting of donor disbursements. The figures reported in Table 4.3, for example, exclude some reported expenditures by EU-member states and Switzerland in Rwanda, as circulated by a recent letter from the Dutch Ambassador to the Hon. Minister of Finance and Economic Planning. 
Transport and Communication saw high execution figures notably on account of a number of EU financed projects: Rehabilitation of Kanombe Airport (disbursement of RWF 5.7 bn compared to a budgeted RWF 2.0 billion), rehabilitation of the Kigali - Kayonza route (RWF 5.8 bn vs 1.9 bn), and repair of the Gitarama - Butare - Akanyaru road (RWF 7.5 bn vs 1.5 bn). In contrast, some other projects (total budged amount of RWF 4.2 billion) failed to disburse completely during 2004, most notably for the improvement of the Kicukiro-Nyamata-Nemba road.

\section{Table 4.2 Budget Allocation and Execution}

\begin{tabular}{|c|c|c|c|c|}
\hline & \multicolumn{2}{|c|}{$\begin{array}{l}\text { Total Budget } \\
\% \text { of GDP }\end{array}$} & \multicolumn{2}{|c|}{$\begin{array}{l}\text { Execution of the } \\
\text { Recurrent Budget }\end{array}$} \\
\hline & 2003 & 2004 & 2003 & 2004 \\
\hline 01 Gen. Public Administr. Services & $9.6 \%$ & $11.9 \%$ & $94.5 \%$ & $84.8 \%$ \\
\hline o/w public debt related transactions & $1.5 \%$ & $5.8 \%$ & $40.1 \%$ & $66.5 \%$ \\
\hline 02 Defence & $3.2 \%$ & $2.7 \%$ & $88.7 \%$ & $98.3 \%$ \\
\hline 03 Justice, Order \& Public Security & $1.9 \%$ & $2.0 \%$ & $104.2 \%$ & $85.7 \%$ \\
\hline 04 Environment & $0.2 \%$ & $0.2 \%$ & $35.5 \%$ & $50.8 \%$ \\
\hline 05 Agriculture & $1.1 \%$ & $1.5 \%$ & $63.5 \%$ & $93.0 \%$ \\
\hline 06 Industry and Commerce & $0.4 \%$ & $0.4 \%$ & $72.8 \%$ & $76.5 \%$ \\
\hline 07 Energy & $0.5 \%$ & $0.4 \%$ & $67.4 \%$ & $73.4 \%$ \\
\hline 08 Transport and Communication & $1.2 \%$ & $1.5 \%$ & $103.4 \%$ & $77.3 \%$ \\
\hline 09 Community dev, Land, Housing & $0.7 \%$ & $0.8 \%$ & $91.3 \%$ & $67.2 \%$ \\
\hline 10 Water and Sanitation & $0.5 \%$ & $0.5 \%$ & $52.3 \%$ & $48.7 \%$ \\
\hline 11 Youth, Culture, and Sports & $0.2 \%$ & $0.3 \%$ & $98.6 \%$ & $100.6 \%$ \\
\hline 12 Health & $1.2 \%$ & $1.6 \%$ & $94.8 \%$ & $94.2 \%$ \\
\hline o/w primary and secondary health care & $0.4 \%$ & $0.4 \%$ & $78.2 \%$ & $74.8 \%$ \\
\hline o/w specialist health care services & $0.3 \%$ & $0.7 \%$ & $96.9 \%$ & $133.3 \%$ \\
\hline 13 Education & $4.6 \%$ & $4.7 \%$ & $112.6 \%$ & $104.1 \%$ \\
\hline o/w primary and pre-primary & $2.2 \%$ & $1.8 \%$ & $122.2 \%$ & $100.2 \%$ \\
\hline o/w secondary & $0.3 \%$ & $0.7 \%$ & $111.7 \%$ & $90.4 \%$ \\
\hline o/w tertiary & $1.5 \%$ & $1.5 \%$ & $108.3 \%$ & $118.8 \%$ \\
\hline 14 Social Protection & $2.5 \%$ & $3.3 \%$ & $75.7 \%$ & $59.8 \%$ \\
\hline Total & $27.8 \%$ & $31.9 \%$ & $95.0 \%$ & $87.3 \%$ \\
\hline
\end{tabular}

Source: MINECOFIN

Good execution figures for the industry and commerce sector are exclusively due to high disbursement of the competitiveness and enterprise development project during 2004. Whereas one other project managed to disburse more than programmed, the remaining 8 projects that were envisaged for this sector failed to disburse at all or disbursed only marginal amounts.

In the agriculture sector, the IDA rural sector support project disbursed RWF 4 bn compared to a budgeted RWF 1.8 bn, whereas a special export promotion project for tea, coffee and horticulture used only about a third of the allocated RWF 4.9 billion. Most other projects disbursed around 70 per cent or less of the budgeted amounts.

A large number of small projects were envisaged in the community development, land, and housing sector, which, with a few exceptions, all performed relatively poorly. Similarly, the 
CDF disbursed only RWF 2.1 billion compared to a budgeted amount of RWF 5.5 billion. Performance of the CDF was more closely discussed in section 4.2.3.

Of the largest external donors to the development budget, reported execution rates were high for the EU (133\%) and IDA (147\%), while the AfDB performed poorly (29\%).

\section{Table 4.3 Development Budget 2004}

\begin{tabular}{lrrr}
\hline SECTOR & $\begin{array}{r}\text { Budget } \\
\text { in RWF million }\end{array}$ & $\begin{array}{r}\text { Execution } \\
\text { in RWF million }\end{array}$ & $\%$ \\
Transport \& Communication & 12,099 & 20,505 & $169 \%$ \\
Education & 8,852 & 4,234 & $48 \%$ \\
Health & 7,473 & 6,546 & $88 \%$ \\
Industry \& Commerce & 3,181 & 3,881 & $122 \%$ \\
Agriculture & 11,409 & 7,773 & $68 \%$ \\
Community dev, Land, Housing & 10,034 & 6,277 & $63 \%$ \\
Justice, Order \& Public Security & 4,974 & 3,448 & $69 \%$ \\
Water sanitation & 5,161 & 3,138 & $61 \%$ \\
Gen. Public Administr. Services & 6,915 & 1,377 & $20 \%$ \\
Social & 3,208 & 1,438 & $45 \%$ \\
Environment & 1,538 & 90 & $6 \%$ \\
Defence & 688 & 290 & $42 \%$ \\
Youth, Culture \& Sports & 1,884 & 507 & $27 \%$ \\
Energy & 4,283 & 19,861 & $464 \%$ \\
Transfers to districts (CDF) & 5500 & 2062.5 & $38 \%$ \\
\hline Total & $\mathbf{8 7 , 2 0 0}$ & $\mathbf{8 1 , 4 2 7}$ & $\mathbf{9 3 \%}$ \\
\hline
\end{tabular}

*Figures for the Development Budget are based on the sectoral breakdown as provided by CEPEX, which differs somewhat from those presented in the (revised) Budget Law and contained in Table 4.2

Source: CEPEX

\subsection{Aid Coordination and Harmonisation in 2004}

In 2004, a great deal was achieved in the field of aid coordination and harmonisation. Both the government and donors have been fully committed to making aid more effective and continue to support coordination and harmonisation both financially and through enthusiastic participation in the coordination structures.

In 2002 and 2003, there were a number of "headline" developments, including the signing of the Budget Support Harmonisation Framework and the setting-up of both the Development Partners Coordination Group (DPCG) and the Budget Support Harmonisation Group (BSHG). In contrast, 2004 served as an important year for consolidation and the bedding-in of these new mechanisms. In December 2004, the government hosted the Development Partners Meeting in Kigali. This proved an excellent opportunity for both government and development to discuss important issues at a high level and take stock of the progress in Harmonisation and coordination. 


\subsubsection{Development Partners Coordination Group}

The DPCG was assembled for the first time on 18 November 2002 following the 2002 DPM. Since January 2004, the DPCG has convened on a monthly basis and gained momentum. It is well attended by the heads of development cooperation and by representatives from MINECOFIN, but it rarely attended by representatives from other Ministries. By the end of 2004, there was yet to be any NGO or Civil Society involvement at the monthly meetings. The level of discussions has primarily been focused on macro-level issues - including NEPAD and the PRS Annual Progress Review and PRSC process. It also provides a forum for sharing the progress made by various clusters and the reform of the cluster system as a whole. It is proving to be an increasingly effective forum for information exchange, and the monitoring of processes or commitments undertaken by development partners.

In December 2004, a website was under development to facilitate transparency and improved information exchange, while decreasing the amount of time individuals need to spend in meetings. In January 2005, the first annual DPCG retreat was held in Gisenyi. This provided an excellent opportunity for all stakeholders to take stock of the harmonisation and coordination process and look forward to the plans for the coming year. It was especially encouraging, that so many representatives of the line ministries attended the retreat and provided invaluable contributions to the debate.

To support the DPCG and its associated functions, including coordination and support to the cluster system, a multi-donor project has been put in place in 2004 under the United Nations Resident Coordinators Office. This project, named the DPCG secretariat, is funded by CIDA, DFID, the Netherlands, the SDC, and SIDA. The DPCG secretariat is responsible for supporting the DPCG and Cluster system - providing logistical support to the structure, as well as spearheading pilots and initiatives on coordination, harmonization and alignment in Rwanda. It reports regularly to the DPCG and is supported by the HARPP and guided by the steering committee composed of its constituent donors. After one year, the plan is to transfer the secretariat to MINECOFIN.

\subsubsection{Budget Support Harmonization Group}

All the members of the BSHG (apart from the IMF) signed the Partnership Framework for Budget Support Harmonisation in November 2003. The group has been meeting quarterly and has been an important forum for the Budget Support Donors to discuss pertinent issues and further coordinate their activities. The framework is built around 3 annual review processes: Public Financial Management, Macroeconomics and PRS M\&E. There were two major Public Financial Management Reviews in 2004, which provided all stakeholders with a comprehensive discussion on all PFM issues.

\subsubsection{Harmonization and Alignment in Rwanda of Projects and Programmes Group (HARPP)}

The HARPP Group, initiated through the DPCG in June 2004, resulted from recommendations from various missions (SPA 2002, 2003, Niloy Banjeree 2003) and from the interest of development partners. The HARPP's partnership principles, build on the resolutions of The Monterrey Consensus (March 2002), The Rome Declaration (February 2003), the OECD-DAC Best Practice Principles, and take as a starting point the Government's Poverty Reduction Strategy. These principles complement the Budget Support Donors' Partnership Framework of 
November 2003 to expand the country's harmonization agenda, beyond budget support harmonization, to programmes and projects.

Despite initial teething problems, the HARPP is now enjoying greater participation from both the government and the development partners as its position in the harmonisation framework becomes clearer.

\subsubsection{Looking forward to 2005}

In January 2005, the Government of Rwanda created the External Finance Unit. This will be charged with handling all elements of aid policy including the negotiation of individual aid programmes as well as the harmonisation and coordination process. The Unit will be based in MINECOFIN and will be the first point of contact in the government for all development partners.

On of the major tasks that the government has set the unit is the creation of an Aid Policy Document. This will set out the government's policy for making all external finance more effective in achieving poverty reduction and will propose concrete actions for the government to undertake. It is hoped that although this will be a government policy rather than a joint assistance strategy, it will pave the way for such a document in the future. It will also allow government to play a stronger role in aid harmonisation. 


\section{Agricultural Transformation and Rural Development}

This chapter focuses mainly on progress and developments in the area of agricultural transformation. Other aspects of rural development such as improvement in livelihood of rural populations, rural infrastructures, micro-credit and non-farm employment are dealt with in more detail within other chapters. However, this chapter gives an overview of developments in providing credit and creating non-farm employment. Due to its strong connection with this sector, the cross-cutting issue of environment and land management follows directly.

\subsection{Agricultural Transformation}

To fulfil its role as stated in Rwanda's Vision 2020 and PRSP, the agriculture sector should achieve $5-8 \%$ annual growth. Unfortunately, over the last three-year period, growth in the sector averaged only $3.6 \%$. Considering only the last two years, where the agriculture production has been subject to adverse climatic conditions, overall annual growth has been of $1.64 \%$ while food crops alone decreased by $2.8 \%$. These lower than expected growth rates imply that the agriculture sector is not on-track relative to the targets for poverty reduction and increased rural incomes. However, in 2004, the increase in export crops (particularly coffee) somewhat compensated for the reduced food crop production resulting into an overall agriculture growth of $0.8 \%$.

In response, the Government has undertaken actions in 2004 and 2005 to reduce the heavy dependence on rains and boost food crop production while keeping the same focus on export crops. An action plan $2005-2008$ was developed to implement the Strategic Plan of the Agricultural Transformation (PSTA) that promotes:

- the reinforcement of professionalisation and specialization of agriculture;

- selection of a number of priority crops decreasing from the national to the sector (Umurenge) level;

- exports crops and their regionalization to reduce production costs and optimize comparative advantages;

- partnership with the private sector encouraging its participation in agriculture transformation.

\subsection{Performance of the sector}

\subsubsection{Food production (crops and animal):}

The following table shows variations in farm production (food crops and animal) and summarises the main underlying reasons for these variations over 2003-04. 
Table 5.1 Evolution of priority crops and animal production

\begin{tabular}{|c|c|c|c|c|c|c|c|}
\hline \multirow[t]{2}{*}{ Crops/livestock } & \multicolumn{4}{|c|}{ Production } & \multicolumn{2}{|c|}{ Variation 2003/2004 } & \multirow[t]{2}{*}{ Comments } \\
\hline & Total 2001 & Total 2002 & Total 2003 & Total 2004 & Tonnes & $\%$ & \\
\hline Sorghum & & & 166,139 & 163,772 & $-2,367$ & -1.42 & Long dry season \\
\hline Maize & 92,129 & 91,686 & 78,174 & 88,209 & 10,035 & 12.84 & Increase in number of producers, extended cultivated area \\
\hline Wheat & & & 16,193 & 16,772 & 579 & 3.58 & Increase in number of producers, extended cultivated area \\
\hline Rice & 17,697 & 24,539 & 34,056 & 46,190 & 12,134 & 35.63 & Increase in number of producers, extended cultivated area \\
\hline Beans & 289,983 & 246,906 & 217,242 & 198,225 & $-19,017$ & -8.75 & Insufficient rains \\
\hline Peas & & & 17,109 & 16,758 & -351 & -2.05 & Insufficient rains \\
\hline Groundnuts & & & 10,219 & 10,785 & 566 & 5.54 & Increased production in eastern Rwanda \\
\hline Soya & 17,140 & 19,216 & 16,799 & 18,251 & 1,452 & 8.64 & Increase in cultivated area \\
\hline Bananas & & & $2,490,022$ & $2,469,741$ & $-20,281$ & -0.81 & Insufficient rains and disease \\
\hline Irish Potatoes & $1,012,269$ & $1,038,931$ & $1,064,280$ & $1,072,771$ & 8,491 & 0.8 & No change \\
\hline Sweet potatoes & & & 995,723 & 908,306 & $-87,417$ & -8.78 & Insufficient seeds \\
\hline Yam and colocase & & & 141,280 & 136,359 & $-4,921$ & -3.48 & Abandonment of these crops due to the markets orientation \\
\hline Cassava & & & $1,104,352$ & 912,108 & $-192,244$ & -17.41 & Persistence of mosaic disease \\
\hline Horticulture & & & 615,635 & 547,775 & $-67,860$ & -11.02 & Persistence of disease \\
\hline \multicolumn{8}{|c|}{ Livestock sub-sector } \\
\hline Milk & & 97,981 & 112,463 & 121,417 & 8,954 & 7.4 & Import and dissemination of improved breeds \\
\hline Meat & & 39,126 & 43,589 & 48,681 & 5,092 & 10.5 & Intensification and improvement of breeding techniques \\
\hline Fish & & 7,612 & 8,144 & 8,126 & $-0,018$ & -0.2 & Countrywide prohibition of fishing \\
\hline Eggs & & 2,434 & 3,402 & 3,452 & 0,050 & 1.5 & Introduction of chickens \\
\hline Honey & & 819 & 908 & 1,029 & 121 & 11.8 & The promotion of reforestation contributed enormously to this increase \\
\hline
\end{tabular}

\section{Source: MINAGRI}

CInternational Monetary Funđa.4Not for Redistribution 
When compared to the consumption basket of the three poorest quintiles in $\mathrm{Rwanda}^{4}$, the above table gives an alarming picture in terms of the likely impact of the evolution of food production both on food security and the overall poverty of the population. Production of 5 of the 6 major crops has been declining over time. These are, ranked by order of importance sweet potatoes, beans, banana, cassava and sorghum (Irish potatoes being the exception). Taken together, these 5 crops constitute more than $70 \%$ of the consumption basket. This figure goes as high as $79 \%$ when one considers their caloric content.

Exceptionally, production of Irish potatoes has been consistently increasing over the last years. This crop is mainly cultivated in areas where climatic shocks are not strongly felt and takes the biggest proportion of improved seeds production in Rwanda.

In order to reduce the heavy dependence on rains, the Government has been promoting modern inputs. More seeds were disseminated (952 tonnes for potato, 205 tonnes for cereals, 58.6 tonnes for roots/tubers and 8 tonnes for sunflowers). While a mechanism has been put in place to inspect quality of seeds produced, MINAGRI in collaboration with RRA have produced a list of phytosanitary products that can be imported legally in Rwanda. At the same time, fertilisers continue to be exempt from duties up to mid-2005 and credit lines were opened with BNR, BRD and UBPR to facilitate the importation and promote the use of fertilisers. Supporting interventions included improved management of soil and natural resources through increased radical terraces, installation of valley dams and collection of rain water.

In the 2005 Budget, resources have been allocated for direct transfers to districts to provide seeds seasonally to farmers. MINAGRI envisages promoting the use of organic residues from harvests, currently used to supplement wood ${ }^{5}$. It also plans to establish a centre for technology transfer and a centre for fast multiplication of cassava and banana. Then a centre for technological innovation will be established in each agro-bioclimatic zone.

Production of cereals deserves mention. With the exception of sorghum, these (rice, wheat and maize) increased in 2004. Rice is another priority crop for which production has been continuously increasing, more than doubling over the last three years. The national production covered $28 \%$ of needs in $2001,50 \%$ in 2002 and $60 \%$ in 2003-04, thereby reducing imports. The rise in production results from an increased number of producers, due to the income generated by production of this crop and extension of the cultivated area (rice cultivated area rose from 6500 ha to $7455 \mathrm{ha}$ ). MINAGRI plans to increase the area covered by rice plantations up to 11,813 ha in 2009 .

Production of wheat was hampered by the lack of processing factories. This constraint has been partially removed in 2005 but Rwanda still imports 14,000 tons of wheat every year (at a value of approximately $\$ 20$ Million). Two flour mills are about to open in Gikongoro and Byumba provinces.

\footnotetext{
${ }^{4}$ MINECOFIN, A Profile of Poverty in Rwanda, February 2002

${ }^{5}$ According to a joint study by ISAR and ICRAF (Promotion of the Agro-forestry to increase its impact on reduction of poverty and Environmental protection in Rwanda.2003), the insufficiency of wood result into use of residues of harvests estimated at 1,7 tons per ha and per annum. These are equivalent to 40.000 tons of manure and 33.000 tons of lime
} 
The processing capacity for maize increased by a quantity equivalent to $75 \%$ of current national production.

Overall animal production has gradually increased, with the exception of fish, for the last year, as a consequence of the Government's campaign on importing improved breeds and extension services (artificial insemination, vaccination, etc.). However, it is important to note that neither food crop production nor animal production meet the needs of the population. The current level of production satisfies only $39 \%$ of the need for milk; $86 \%$ for meat; $55 \%$ for fish and $10 \%$ for eggs.

\subsubsection{Priority export crops}

The table below shows a net increase in volume of production for most export crops, with the exception of tea production, which has been decreasing over the last three years. As mentioned above, in 2004, the overall performance of export crops compensated for the reduction of food crops. This increase was driven mainly by a near doubling of coffee production. Despite plant diseases, production of fruits and vegetables has continued to grow. As a consequence of increased livestock rearing and meat production, the production of hides and skins also more than doubled.

Table 5.2 Export crops production in tons

\begin{tabular}{|c|c|c|c|c|c|c|c|}
\hline \multirow{2}{*}{$\begin{array}{l}\text { Crop/prod } \\
\text { uct } \\
\end{array}$} & \multicolumn{4}{|c|}{ Production in tons } & \multicolumn{2}{|c|}{ Variation } & \multirow[t]{2}{*}{ Observation } \\
\hline & 2001 & 2002 & 2003 & 2004 & Tonnes & $\%$ & \\
\hline Coffee & 18,260 & 19,426 & 14,600 & 29,000 & 14,400 & 98.6 & $\begin{array}{l}\text { New strategy, new investments in sector } \\
\text { (PEARL, ADAR and STABEX) }\end{array}$ \\
\hline Tea & 15,166 & 11,941 & 11,900 & 11,700 & -200 & -1.7 & Reduction due to weather (night dew) \\
\hline Pyrethrum & & & 1,000 & 1,250 & 250 & 25.0 & RSSP supported SOPYRWA \\
\hline Sugar Cane & & & 7,000 & 7,500 & 500 & 7.1 & Increased cultivated area \\
\hline Flowers & & & 0 & 50 & 50 & & Rwanda Flora started operations in 2004 \\
\hline $\begin{array}{l}\text { Fruits and } \\
\text { Vegetables }\end{array}$ & 211,038 & 233,643 & 267,568 & 280,000 & 12,432 & 4.6 & $\begin{array}{l}\text { Increased number of producers of } \\
\text { vegetables, increased cultivated area but } \\
\text { need to replace old trees for fruits }\end{array}$ \\
\hline $\begin{array}{l}\text { Skins and } \\
\text { hides }\end{array}$ & & & 982 & 2,000 & 1,018 & 103.7 & \\
\hline
\end{tabular}

Source: MINAGRI

Cultivation of coffee is practiced by 400,000 producers in 60 Districts of the country. After a strong decrease in production in 2003, it more than recovered in 2004 with a $98.6 \%$ increase in production and a $114.8 \%$ increase in value terms. Hence, in 2004, earnings from coffee exports overtook earnings from tea exports. However, there is still room for improvement since last year's production remains far below 1986 pre-war levels (43,000 tons in 1986 compared to 
29,000 in 2004). The government's strategy has begun to yield results, with fully washed coffee increasing from 270 tons in 2003 to 700 tons in 2004 thanks to an increase in the number of washing stations from 13 in 2003 to 20 in 2004. The expected number of washing stations for 2005 is 35 . At the same time, the overall quality of coffee production has improved with standard coffee comprising only $35 \%$ of national production (as compared to $48 \%$ in 1986 and $2.5 \%$ in 1995). The government also opened a guarantee facility, held with BNR and accessible to commercial banks, for the coffee campaign.

Table 5.3 Exports earnings for coffee and tea in Millions of USD

\begin{tabular}{|l|l|l|l|l|l|}
\hline Crop & 2001 & 2002 & 2003 & 2004 & $\begin{array}{l}\text { Variation } \\
2003 / 04\end{array}$ \\
\hline Coffee & 19.4 & 14.6 & 15 & 32.2 & $114.8 \%$ \\
\hline Tea & 22.7 & 22.0 & 22.5 & 21.6 & $-4.2 \%$ \\
\hline
\end{tabular}

Source: MINECOFIN, Annual economic report, March 2005

Plantations of tea cover 12,862 ha with the capacity of factories amounting to 15,500 tons of processed tea per annum. Tea producers and factory employees together number 52,838 people. Although volumes of tea produced have been decreasing over the years, export earnings have remained almost constant due to price changes and improved quality of leaves. In 2004, a premium was introduced to encourage good quality of leaves (premium of $2 \mathrm{RwF} / \mathrm{kg}$ of green leaves for a quality of more than $70 \%$ of good leaves) and transport conditions at the time of export were improved resulting in Rwandan tea being first for quality in Mombasa tea auctions.

Production of pyrethrum flowers amounted to 4,000 tons last year with a corresponding income of RwF 200 million for the estimated 25,000 growers. A refinery started with a capacity of $500 \mathrm{~kg}$ per day and cultivation has been extended to other Provinces, providing an opportunity to supply the regional market.

A feasibility study for financial support to the diversification of agricultural exports (European Union, 2003) identified 40 products with potential for development. These included a macadamia crop with its high economic potential (last year ISAR imported a good quantity from Kenya for multiplication and dissemination) and medicinal plants (Moringa, Nym and Geranium) in Kibungo, Kigali Ngali and Butare provinces.

\subsection{Credit and off-farm employment}

In order to facilitate imports of fertilisers, a credit line was opened with BNR whilst the GoR made funds available (RwF 124 million) through Banques Populaires for microfinancing of seasonal credit. This will ensure improved access for rural households to financial and in-kind resources. The Government also opened a guarantee fund with BNR to support the coffee campaign and this has recently been converted into an agricultural guarantee facility. 
A regulatory framework for the microfinance sector was established and a national microfinance policy has been developed.

The GoR also programmed transfers of funds to decentralised entities, through the budget, for seasonal credit to purchase seeds. Meanwhile, the BRD has been restructured to assist the Government in implementing its strategy by supporting the private sector. This support includes a microfinance scheme to refinance microfinance institutions and additional funds to finance export promotion.

The HIMO programme elaborated in 2003 started to operate in 2004 in co-ordination with the $\mathrm{CDF}$ and Ubudehe programmes. This includes using the HIMO approach for terracing, marsh management, construction of feeder roads, protection of hillsides, etc. thereby simultaneously developing needed infrastructure and boosting rural off-farm employment (see social protection chapter).

\subsection{Monitoring and Evaluation}

There are still several deficiencies in the monitoring system of the agriculture sector. Information is not always readily available to key actors in the sector. MINAGRI envisages establishing, in the framework of the national information system, an early warning system for livestock diseases.

Another problem has been weak coordination between the central Government, Provinces and Districts. The elaboration of the PSTA is only a first step toward improved coordination of actors and increased participation in agricultural development. The rural development cluster created in 2002 has not yet been able to play a full role as a partnership forum.

\subsection{Budget execution}

Tables 5.4 and 5.5 below present a summary of the recurrent budget and development budget execution respectively. Though it is not always possible to link programme execution rates to the overall performance of the sector, the tables can give some hint as to problematic areas.

In 2004, extension and marketing and planning and agricultural statistics were the worst performing programmes with execution rates of $21 \%$ and $40 \%$ respectively. The $21 \%$ execution rate in extension and marketing reflects a shortage of human resources for extension and training. The same is true for the project to train development agents under the development budget. Planning and agricultural statistics experienced very low execution rates for almost all credit items (agriculture planning, agriculture statistics, studies and projects and ICT). Within the programme of livestock development that experienced an average execution rate of $58 \%$, veterinary services performed very badly with a $4.8 \%$ execution rate. 


\begin{tabular}{|c|c|c|c|}
\hline \multicolumn{4}{|l|}{ RECURRENT EXPENDITURE -2004} \\
\hline & Budget & Engagement & Exec. Ratio \\
\hline AGRICULTURE & 4068177192 & 3784599127 & $\mathbf{9 3 , 0}$ \\
\hline MINAGRI & 3285871444 & 3107008794 & 94,6 \\
\hline CABINET & 64303782 & 124310638 & 193,3 \\
\hline AGRICULTURE PRODUCTION & 2042072744 & 2347046219 & 114,9 \\
\hline LIVESTOCK DEVELOPMENT & 777498838 & 453877033 & 58,4 \\
\hline FOREST RESOURCES & 31494000 & 23288161 & 73,9 \\
\hline EXTENSION AND MARKETING & 215716151 & 45553837 & 21,1 \\
\hline PLANNING AND AGRICULTURE STATISTICS & 51986224 & 20794365 & 40,0 \\
\hline MANAGEMENT AND SUPPORT SERVICES & 102799705 & 92138541 & 89,6 \\
\hline MINITERE & 84906114 & 32297818 & 38,0 \\
\hline FOREST RESOURCES & 84906114 & 32297818 & 38,0 \\
\hline PROVINCES & 697399634 & 645292515 & 92,5 \\
\hline AGRICULTURE, LIVESTOCK AND ENVIRONMENT DEVELOPMENT & 697399634 & 645292515 & 92,5 \\
\hline SUPPORT TO MANAGEMENT & 433474478 & 433254317 & 99,9 \\
\hline FOREST RESOURCES & 83720666 & 70916033 & 84,7 \\
\hline AGRICULTURE PLANNING & 17786460 & 13699826 & 77,0 \\
\hline AGRICULTURE PRODUCTION & 50887677 & 38291848 & 75,2 \\
\hline ANIMAL PRODUCTION & 111530353 & 89130491 & 79,9 \\
\hline
\end{tabular}

\section{Source: MINECOFIN}

Table 5.5 Development budget execution 2004 in RwF (unless otherwise indicated)

\begin{tabular}{|c|c|c|c|}
\hline Service and Programme & Budget & Engagement & Observation \\
\hline $\begin{array}{l}\text { Training of development agents and } \\
\text { agricultural professionals }\end{array}$ & 100.000 .000 & - & Not withdrawn \\
\hline Guarantee funds & 300.000 .000 & 150.000 .000 & $\begin{array}{l}\text { Used for the promotion } \\
\text { of exports and fertilizers }\end{array}$ \\
\hline $\begin{array}{l}\text { Institutional support to the } \\
\text { department of agriculture }\end{array}$ & 50.000 .000 & 50.000 .000 & $\begin{array}{l}\text { Used for the promotion } \\
\text { of exports and fertilizers }\end{array}$ \\
\hline RSSP & 5.559 .630 .916 & 3.811 .856 .504 & $\begin{array}{l}\text { The rate of execution is } \\
50.72 \%\end{array}$ \\
\hline STABEX & $641.599 .999 *$ & - & Not yet available \\
\hline PDCRE & 1.796 .747 .200 & 2.519 .116 .886 & $\begin{array}{l}72.7 \% \text { of over-execution } \\
\text { due to launch phase in } \\
2004 \\
\end{array}$ \\
\hline PADEBEL & 2.998 .166 .209 & 1.190 .745 .055 & $60.3 \%$ \\
\hline PACE & $33.900 .000 *$ & - & Not yet available \\
\hline
\end{tabular}

*resources denominated in currency of the donor

Source: PTBA of projects under MINAGRI

Despite an overall execution rate above $100 \%$, within the agriculture production programme, food crops and industrial crops production experienced execution rate below $40 \%$ (39.6\% and $31 \%$ respectively). 
Across all programmes, the execution rates for the "wages and salaries" item remain below $65 \%$ (with the exception of cabinet and planning), meaning that MINAGRI continues to have staffing problems.

The above observations confirm that extension services are still weak and that planning and monitoring and evaluation (management information) systems require urgent attention, among others, through institutional (including decentralised) and human resource strengthening. 


\section{Cross cutting issue - Environment and Land}

National consultations on land policy and a new land law have been ongoing for most of 2003 and 2004 and a law on expropriation has now been drafted and adopted by Cabinet. The actual land law is currently under debate in Parliament. This law exempts agricultural land from taxes. There has also been progress in land planning and management through better mapping and creation of a database on land use and this has resulted in less bureaucracy in acquiring title deeds. Mechanisms for resolving land related and other disputes (Abunzi) have been established in 2004 through a reform of the justice system.

An environment policy was developed during 2004 and the 'environment organic law' has been adopted by Parliament while the law establishing the Rwanda Environment Management Authority (REMA) is currently being debated in the Senate. A ministerial order prohibiting use of plastic bags is in force since August 2004 and a decision was taken to allocate 5\% of CDF resources to environmental protection activities.

The Forest Protection Service was established in July 2004. 60 million trees were planted in 2004 and forest areas expanded from 503,763 ha in 2002 to 527,653 Ha in 2004. Forest fires have been reduced by about $70 \%$ and 110 local authorities from six provinces were trained in forest management practices.

As outlined in the Energy section of this report, a PHRD-grant financed study last year indicated unsustainable levels of fuel-wood and charcoal use. The government has placed restrictions on the use of these resources and is now moving to purchase diesel-powered brick making machines (brick production is a major drain on fuel-wood and charcoal resources) from South Africa through KIST, in its capacity to promote new science and technology.

The table below shows that good progress has been made in integrating environment in the programmes of the Government: 
Table 6.1 Integration of the environment in government and partner programmes

\begin{tabular}{|c|c|c|}
\hline Sector & Key partners & Current progress as regards integration \\
\hline Agriculture & $\begin{array}{l}\text { MINAGRI } \\
\text { ISAR } \\
\text { MINALOC } \\
\text { MINEDUC } \\
\text { PAFOR } \\
\text { ONG }\end{array}$ & $\begin{array}{l}\text { The PSTA of MINAGRI integrates environmental aspects } \\
\text { In collaboration with ISAR in research on forestry, a list of the species } \\
\text { appropriate to various areas has been published. } \\
\text { Introduction of the species requires preliminary studies } \\
\text { Conservation of soil and the fight against erosion is one of the top } \\
\text { priorities of Provinces and Districts } \\
\text { Reclamation of marshes takes account of environmental aspects }\end{array}$ \\
\hline Infrastructure & $\begin{array}{l}\text { MININFRA } \\
\text { FRSP } \\
\text { KIST } \\
\text { IRST }\end{array}$ & $\begin{array}{l}\text { The energy policy envisages the promotion of new and renewable energies } \\
\text { Exploitation of Methane } \\
\text { The sector strategies take into account the environmental impact of } \\
\text { infrastructure building } \\
\text { The housing policy emphasizes regional planning and city planning and } \\
\text { the development of "imidugudu" sites }\end{array}$ \\
\hline Education & $\begin{array}{l}\text { MINEDUC } \\
\text { ORINFOR MINALOC, } \\
\text { RITA }\end{array}$ & $\begin{array}{l}\text { Plan of environmental training and education } \\
\text { School infrastructures } \\
\text { The education policy emphasizes environmental protection }\end{array}$ \\
\hline Private sector & $\begin{array}{l}\text { MINICOM } \\
\text { RIEPA } \\
\text { FRSP }\end{array}$ & $\begin{array}{l}\text { The national investment strategy and sector strategies of MINICOM state } \\
\text { that all investment plans must take into account environmental aspects } \\
\text { Privatization of forest areas }\end{array}$ \\
\hline $\begin{array}{l}\text { Strategic } \\
\text { planning and } \\
\text { poverty reduction }\end{array}$ & $\begin{array}{l}\text { MINECOFIN } \\
\text { UNDP } \\
\text { Embassies of the } \\
\text { Netherlands } \\
\text { DEMP } \\
\text { CDF } \\
\end{array}$ & $\begin{array}{l}\text { Well elaborated MTEF } \\
\text { It is planned that PRSP2 will better reflect environmental aspects } \\
\text { District development plans with integrated environmental plans }\end{array}$ \\
\hline $\begin{array}{ll}\text { Regional } & \text { and } \\
\text { international } & \text { co- } \\
\text { operation } & \end{array}$ & $\begin{array}{l}\text { MINAFFET } \\
\text { Secretariat of } \\
\text { Conventions } \\
\text { PNUE/UNEP } \\
\text { Regional and sous- } \\
\text { régionales international } \\
\text { organisations } \\
\text { Embassies } \\
\end{array}$ & $\begin{array}{l}\text { The co-operation framework is well defined and co-operation } \\
\text { memoranda/agreements of partnership signed } \\
\text { Implementation of conventions } \\
\text { Participation in regional and international fora }\end{array}$ \\
\hline $\begin{array}{l}\text { Gender and } \\
\text { environment }\end{array}$ & $\begin{array}{l}\text { MIGEPROFE } \\
\text { PRO-FEMMES } \\
\text { Networks of the women } \\
\text { A-habitat }\end{array}$ & $\begin{array}{l}\text { The gender policy integrates environmental aspects } \\
\text { Women are actively involved in management of natural resources and } \\
\text { environment }\end{array}$ \\
\hline $\begin{array}{l}\text { Work of general } \\
\text { interest }\end{array}$ & $\begin{array}{l}\text { MINIJUST } \\
\text { MINALOC } \\
\text { Provinces } \\
\text { Districts } \\
\text { Gacaca jurisdiction } \\
\text { MININTER }\end{array}$ & $\begin{array}{l}\text { Activities related to environmental protection are envisaged in the policy } \\
\text { and the law on the TIG }\end{array}$ \\
\hline $\begin{array}{l}\text { Decentralization } \\
\text { and good } \\
\text { governance }\end{array}$ & $\begin{array}{l}\text { MINALOC } \\
\text { CDF } \\
\text { Districts }\end{array}$ & $\begin{array}{l}\text { The policy of decentralization and the law on the operation of the districts } \\
\text { and cities attribute responsibility for environment protection and } \\
\text { management to these decentralized entities } \\
\text { The policy and the law on Community work "umuganda" envisage } \\
\text { activities of environmental protection }\end{array}$ \\
\hline
\end{tabular}




\section{Human Development - Health}

\subsection{Key Objectives of the Sector}

To achieve its mission of maintaining and improving the health status of the population, the Ministry of Health has defined the following objectives in its strategic plan:

1. Improve the availability of human resources;

2. Improve the availability of quality drugs, vaccines and consumables;

3. Expand the geographical access to health services;

4. Improve financial access to health services;

5. Improve the quality of and demand for services in the control of disease;

6. Strengthen national referral hospitals and treatment and research centres;

7. Strengthen the sector's institutional capacity.

\subsection{Key Indicators in the Health Sector}

\begin{tabular}{|c|c|c|c|c|}
\hline Results & $\begin{array}{l}\text { Key Performance Indicators } \\
\text { Expected progress } 2004\end{array}$ & 2003 Actuals & 2004 Actuals & Underlying Hypotheses \\
\hline $\begin{array}{l}\text { Human Resources } \\
\text { are available }\end{array}$ & $\begin{array}{l}30 \% \text { of health centres fulfil } \\
\text { staffing norms } \\
\text { Doctors per inhabitant: } \\
1 / 50000 \\
\text { Nurses per inhabitant: } \\
1 / 3.900 \\
\% \text { of nurses in rural areas: } \\
17 \%\end{array}$ & $\begin{array}{l}37 \% \\
1 / 48000 \\
1 / 3.900 \\
18 \%\end{array}$ & $\begin{array}{l}42 \% \\
1 / 45000 \\
1 / 2.800 \\
20 \%\end{array}$ & $\begin{array}{l}\text { Behaviour change is not } \\
\text { inhibited by cultural factors }\end{array}$ \\
\hline $\begin{array}{l}\text { Drugs, vaccines and } \\
\text { consumables } \\
\text { available }\end{array}$ & $\begin{array}{l}\text { Average out of stock days } \\
\text { for essential drugs: } 1 \\
\text { Availability of essential } \\
\text { drugs: } 100 \% \\
\% \text { of health centres having } \\
\text { vaccines available: } 83 \% \\
\% \text { of health centres having } \\
\text { condoms available: } 64 \% \\
40,000 \text { units of blood } \\
\text { distributed through district } \\
\text { and referral hospitals }\end{array}$ & $\begin{array}{l}85.5-97.2 \% \\
85 \% \\
65 \% \\
40,000 \text { units }\end{array}$ & $\begin{array}{l}1.7 \text { days } \\
85.5 \% \\
94,6 \% \\
\mathrm{~N} / \mathrm{A} \\
\\
28,777 \text { units } \\
\text { distributed }\end{array}$ & $\begin{array}{l}\text { Effective regulation of sector } \\
\text { put in place } \\
\text { National policy on generic } \\
\text { drug use not inhibited }\end{array}$ \\
\hline
\end{tabular}




\begin{tabular}{|c|c|c|c|c|}
\hline $\begin{array}{l}\text { Improved } \\
\text { geographical access } \\
\text { to health services }\end{array}$ & $\begin{array}{l}\text { Rate of Utilisation of } \\
\text { Curative Services } \\
\% \text { living within } 5 \mathrm{~km} \text { of } \\
\text { health centre: } 58 \% \\
\% \text { of health centres } \\
\text { possessing transport for } \\
\text { emergency referral: } 32 \%\end{array}$ & $\begin{array}{l}74.2 \% \\
32 \%\end{array}$ & $\begin{array}{l}37.9 \% \\
74,2 \% \\
50 \%\end{array}$ & $\begin{array}{l}\text { Government and donor } \\
\text { financing of health services } \\
\text { remains at current levels }\end{array}$ \\
\hline $\begin{array}{l}\text { Improved financial } \\
\text { access to health } \\
\text { services }\end{array}$ & $\begin{array}{l}\text { Share of government budget } \\
\text { allocated to health: } 6,1 \% \\
\% \text { of population enrolled in } \\
\text { mutuelle insurance: } 12 \%\end{array}$ & $4.8 \%$ & $\begin{array}{l}8.2 \% \\
27 \%\end{array}$ & $\begin{array}{l}\text { Donors maintain or augment } \\
\text { health sector financing in a } \\
\text { predictable manner } \\
\text { Government expenditure on } \\
\text { health increases progressively } \\
\text { to } 15 \%\end{array}$ \\
\hline $\begin{array}{l}\text { Quality of and } \\
\text { demand for services } \\
\text { in the treatment of } \\
\text { diseases }\end{array}$ & $\begin{array}{l}\text { MALARIA } \\
\% \text { of pregnant women and } \\
\text { children under age of } 5 \\
\text { sleeping under impregnated } \\
\text { mosquito net; } 15 \% \\
\text { HIV / AIDS } \\
\text { Mother child transmission } \\
\text { of HIV: } 5 \% \\
\text { Number of VCT sites: } \\
\text { TBC } \\
\text { Treatment success of DOTS } \\
\text { method: } 58 \% \\
\text { Detection rate of new } \\
\text { tuberculosis cases: } 45 \% \\
\text { EPI/IMCI/RH } \\
\text { DPT3 and measles } \\
\text { vaccination rate: }>80 \% \\
\text { Deliveries assisted by } \\
\text { trained health personnel: } \\
31 \% \\
\% \text { of households with access } \\
\text { to safe drinking water: } 41 \%\end{array}$ & $\begin{array}{l}\text { 19.5\% (pregnant } \\
\text { women) } \\
18 \% \text { (children } \\
\text { under 5) } \\
13.5 \% \\
54 \\
63.3 \% \text { (2002) } \\
61.3 \% \\
\text { DPT3: } 95 \% \\
\text { Measles: } 89 \% \\
34.2 \%\end{array}$ & $\begin{array}{l}\text { N/A } \\
11 \% \text { vs } 4,2 \% \\
110 \\
67.4 \%\left(2003^{6}\right) \\
62.6 \% \\
\text { DPT3: } 89,4 \% \\
\text { Measles: } 84 \% \\
39.8 \%\end{array}$ & $\begin{array}{l}\text { Positive response of the } \\
\text { population to improved health } \\
\text { services } \\
\text { Growing private sector }\end{array}$ \\
\hline
\end{tabular}

${ }^{6} 2004$ figures will only be available at the end of 2005 due to the length of TB treatment courses 


\begin{tabular}{|c|c|c|c|c|}
\hline $\begin{array}{l}\text { National referral } \\
\text { hospitals and } \\
\text { treatment and } \\
\text { research centres }\end{array}$ & $\begin{array}{l}-10 \text { specialists taught per } \\
\text { year }\end{array}$ & $\begin{array}{l}\text { No specialist } \\
\text { training } \\
\text { programme in } \\
\text { place }\end{array}$ & $\begin{array}{l}\text { Specialist } \\
\text { programme } \\
\text { starting end } \\
2005\end{array}$ & \\
\hline $\begin{array}{l}\text { Institutional capacity } \\
\text { reinforced }\end{array}$ & $\begin{array}{l}\text { Development of results } \\
\text { oriented MTEF linked to } \\
\text { annual budget and } \\
\text { monitoring tools } \\
\text { MTEF monitoring executed } \\
\text { quarterly } \\
\% \text { of districts that have } \\
\text { completed all required } \\
\text { monthly SIS reports for the } \\
\text { year: } 90 \% \\
\% \text { of population living in } \\
\text { areas included in } \\
\text { performance based health } \\
\text { schemes }\end{array}$ & $92 \%$ & $\begin{array}{l}\begin{array}{l}\text { MTEF } \\
\text { developed }\end{array} \\
\text { Annual } \\
\text { monitoring } \\
\text { Starting } 2005 \\
95 \%\end{array}$ & $\begin{array}{l}\text { Decentralisation increases } \\
\text { human and financial capacity } \\
\text { of districts } \\
\text { The implementation of the } \\
\text { PRSP in other sectors has a } \\
\text { positive effect on results in the } \\
\text { health sector }\end{array}$ \\
\hline
\end{tabular}

\subsection{Analysis of Performance in Sector}

\subsubsection{Sector Strategy}

The seven focus areas of the sector strategy are outlined in the key objectives set out above. It is important to note that the use of the "sector wide approach" (SWAp), which guides the cooperation between the government and its partners, began in 2004. In this approach, the Ministry of Health coordinates the activities of government, its development partners and other stakeholders in the sector, based on the strategic plan.

The goal of this cooperation is the support of the health sector strategic plan through the development partners. To reach this goal, coordination and harmonisation processes have been intensified; the government and its partners cooperate closely in technical working groups, which address key questions and challenges in the sector. Since October 2004, these technical working groups have been fully functional and have held quarterly meetings. The topics addressed in these groups are the following:

1. Human resources

2. Contractual approaches in the health sector

3. Mutuelle health insurance

4. The thematic and geographical mapping of intervention of activities in the health sector

5. The integration of HIV/AIDS into the health sector

6. The management of major epidemics

7. Family planning (group planned)

\footnotetext{
${ }^{7}$ All types of performance based health schemes (community-, health centre-, hospital - and mutuelles based are included in this indicator)
} 


\subsubsection{Analysis of progress in the sector}

\section{Improved availability of human resources:}

A human resource development plan is currently being elaborated for the health sector. In the first four months of 2005, 101 medical doctors and 336 nurses and paramedical staff were recruited. This represents good progress when you consider that in 2003 the total numbers of doctors and nurses working in the public sector were 168 and 2157 respectively. In addition, 2005 saw the revision of the teaching curriculum for medical specializations at the NUR faculty of medicine.

However, human resources are still one of the main constraints in the health sector: their availability and quality remain insufficient. Due to the time needed to increase the number of qualified staff, we can expect the availability of human resources to remain a challenge over the coming years.

\section{Improved availability of quality drugs, vaccines and consumables:}

Although some key targets in this area have not been met, there has been progress made in 2004. Remaining stock shortages are attributable to stock and distribution management issues. Unfortunately, there was a decrease in the distribution of blood from 30,786 units in 2003, to 28,777 units in 2004. In addition, there remains limited financial access to drugs for the poorest part of the population, and there is a lack of regional depots for decentralised distribution.

\section{Improvement of geographical access to health services:}

In 2004, 4 new health centres and one district hospital were built and equipped, adding to the 352 health centres and 32 health districts already in place. Equipment has been purchased for a number of existing health facilities. The utilisation of health services stands at $37.9 \%$ corresponding to 0.4 new cases/capita/year, close to WHO developing countries norms of 0.5 new cases. In addition, several pilot sites are to be equipped with telemedicine posts( CHUB, CHUK, KFH, Ruhengeri and Gihundwe) ;

However, geographical access can only be improved very slowly, as significant investments in infrastructure are necessary. In the meantime, the equipment of rural health centres remains inadequate; for example, recently built health centres in Rubona (Muhororo-Gisenyi) and Gatare (Cyangugu) remain without equipment. In addition, the integration of construction, rehabilitation and equipment provision remains inadequate.

The planned definition of the rehabilitation master plan and of the national hospital construction norms will assist the upgrading of health sector infrastructure. In addition, the introduction of support units for topics of health sector reform, of national cells for the introduction of mutuelles and of the promotion of contractual based approaches will also be of benefit. 


\section{Improvement of financial access to health services:}

Mutuelle coverage increased significantly over the year, expanding from $9 \%$ in 2003 to $27 \%$ in 2004. The mutuelle scheme is a highly popular initiative that lowers the financial barriers for the poor to access basic health services. For the poorest of the poor, however, raising even small contributions to the scheme remains a challenge. Government is aiming for Universal Health Insurance Coverage in Rwanda, and is currently looking into the following four challenges: setting of contribution levels, identification of poorest part of population for subsidisation, financing of gap between population's contribution and financing needs, and management of a national framework and creation of local capacities.

The budget share allocated to health increased from $6.1 \%$ in 2003 to $8.2 \%$ in 2004 . The intermediate goal of $12 \%$ of public expenditure remains to be achieved by 2015 . The national implementation of the mutual insurance scheme poses significant financial and managerial challenges.

\section{Improve the quality of and demand for services in the control of disease}

Some of the key constraints on improving the quality of and demand for services to control disease were external, for example a lack of LLITNs for treating malaria, and the detection of multi-resistant cases of TBC. Other challenges include the management of VCT/PMTCT programmes, as well as the integration of HIV/AIDS activities into health centres and with the treatment of other diseases, such as TBC. The low rate of condom use remains a serious concern. Maintaining vaccination rates at the same time as executing programmes such as $\mathrm{VCT}$ / PMTCT / ARV remains a key challenge, as does motivating health centres to improve their health services.

\subsubsection{Summary of budget in the health centres}

Both the engagement of Government and its development partners in the health sector have been significant, whilst the ordinary health budget increased by $7.3 \%$; an increase of $57 \%$ against trends from 2000 and 2001. Total expenditure by Government and its partners stood at Frw 15.7 billion, of which Government financed 54\% and its Development Partners contributed $46 \%$ to the ordinary and development budget.

In 2004, the Government's financing of the health sector represented $8.2 \%$ of the government budget. With a view to attaining the Millennium Development Goals and to fulfilling the Abuja declaration, significant budget increases will be necessary to achieve a $15 \%$ share of government budget by 2015 . 
Specific observations:

- Attainment of the HIPC completion point may allow the Government's contribution to the health sector to stabilize, and to become a more significant part of health sector financing.

- Health sector financing has been highly volatile between 2000 and 2004, seesawing up and down significantly

- External aid to the sector is concentrated in particular on HIV/AIDS and STIs, as well as reproductive health care

- Since 2002, the sector benefits from financing sources on the ordinary budget in the framework of the decentralization programme

- Monitoring and evaluation measures have been introduced to ensure transparency and good management practices in the sector. In this framework, central administrative units support the activities of decentralized structures.

\subsubsection{Monitoring and evaluation in the health sector}

Implemented by end of December 2004:

- National Health Accounts 2002

- PETS 2004

- Service availability mapping (SAM)

- Human Resource Rapid Needs Assessment

- Review of infrastructure and equipment

Planned 2005 -2006:

- Public Expenditure Review

- Review of health information systems and their optimisation

- Mapping of interventions in the health sector

- Study of health worker motivation

- Evaluation of contractual based approach policy

- National Health Accounts 2003

\subsection{Revised Objectives and Indicators}

The Health Sector Strategic Plan, having been adopted in February 2005, represents the current set of objectives and indicators for the sector. Sector reform is especially concentrated on:

- Expansion of mutuelle system to achieve national coverage by 2007

- Development of Human Resources strategy (ongoing)

- Reform of incentives for health workers to be developed

- Establishment of a regulatory framework for the pharmaceutical sector and institution of professional associations 


\section{Cross cutting issue - HIV/AIDS}

Rwanda's strategic approach to a national response to HIV/AIDS is integrated across sectors, decentralized and community based. CNLS have co-ordinated the national response through a collaboration with Ministries, Provinces and Districts, and a wide range of civil society organisations. Rwanda has played a major role in supporting the functioning of regional HIV/AIDS bodies such as PAYA, OPDAS and GLIA, all of which have headquarters in Kigali. Coordination structures at national and decentralized levels have been reinforced, with mechanisms put in place to register all the HIV/AIDS implementing agencies to avoid duplication and uneven distribution of services.

Sectoral plans are drawn from the Multisectoral National Plan 2002-2006 which focuses on five strategic axes: prevention, surveillance of the epidemic; care and support to infected and affected; poverty reduction and gender mainstreaming in AIDS control, and promoting partnerships and multi-sectoral coordination.

According to results of the Joint Mid-Term Review conducted in late 2004, Rwanda has made progress in implementation of a national response to HIV/AIDS. However, due to the dynamic nature of strategies to fight against HIV/AIDS in the national and global arena, it was recommended that the National Strategic Framework for HIV/AIDS Control, its operational Multisectoral National Plan, and the National Plan for Monitoring and Evaluation be revised in 2005 to meet the new global perspectives.

Prevalence and monitoring of the epidemic. The overall prevalence in the country was reestimated based largely on surveillance in antenatal care at 5.1\% (UNAIDS, 2004). This figure is much lower than previous estimates of around 13\% but may not accurately represent the national prevalence rate. This survey showed an important disparity with a $4 \%$ rate in rural areas and $11 \%$ in urban areas. Confirmation of the national rate will be possible with the completion of the new Demographic and Health Survey (DHS III), whose results will be available in early 2006. Future policies and actions will be based on the new DHS prevalence rate.

National-level HIV/AIDS Monitoring and Evaluation has improved. The number of CD4 tests done was recorded at 15,022 in 2003 and went up to 34,000 in 2004. TRAC has expanded and improved the performance of sentinel surveillance sites. However, there is a need to increase use and quality of services. Another important study, the PLACE (Priorities for Local AIDS Control Efforts) - a tool to identify high transmission areas which are areas likely to have a higher incidence of HIV, and specific sites within them where interventions will have the greatest impact - started in the year 2004 to be concluded in the 2005 .

Prevention and awareness-raising of the HIV/AIDS epidemic remains the best option for reducing and mitigating the effect. National-level campaigns were conducted by CNLS to reduce stigma and discrimination. Quarterly and bimonthly journals containing messages about HIV/AIDS, coupled with weekly radio broadcasts mobilized the population in the fight against 
HIV/AIDS. Public leaders at all levels, especially the top level, were more involved than ever before in prevention campaigns, as were the media.

The Education Sector sets HIV/AIDS education as one of its priority concerns, focusing on young children and adolescents. During 2004, more teaching materials (especially radios) were supplied to all schools and the Health and HIV/AIDS section in MINEDUC has been elevated to departmental status. However, there is still a need for more participation by all concerned; teachers, parents, decentralised focal points etc.

MININFRA organized sensitization workshops on prevention methods in the fight against HIV/AIDS in different areas, for example for taxi drivers and motor cyclists.

MIFOTRA are working with CNLS to develop a policy to prevent the spread of HIV in the workplace and support those employees already infected.

\section{Access to treatment}

Treatment to HIV/AIDS is fully integrated into the programmes of MINISANTE. Access to PMTCT steadily increased from 53 sites in 2003 to 121 in 2004.The trend in the proportion of adherent HIV-infected pregnant women receiving a complete course of ARVs has increased from $67.7 \%$ in 2003 to $72 \%$ in 2004 . This increase is largely due to scaling-up of interventions. Likewise, the number of VCT rose from 44 in 2003 to 130 at the end of 2004. Efforts to scaleup services have been made in parallel with institutional capacity building at all levels to ensure quality of services.

Efforts by the Government of Rwanda to negotiate with pharmaceutical companies and to increase resource mobilisation have yielded progress in treatment with ARVs. The number of sites offering ARV increased from 7 in 2002 to 39 in 2004, with a number of persons on ARV rising from 870 in the year 2001 and 3206 in 2003 to 8991 in 2004. Similarly, the cost of ARVs for first line treatment has reduced from 12,093 Rwanda Francs per month in the year 2003 to 10,864 in 2004. In 2004, the Government released a Ministerial decree establishing guidelines for the distribution of ARVs, providing for the free provision of ARVs to poor affected persons or against a token amount of money in a family approach to ensure that women and Children are not left out. Common basket funding was initiated for procurement of ARVs from CAMERWA among the main purchasing agencies Global Fund, MAP, PEPFAR, MSF, BRALIRWA, BNR and UNDP.

\section{Support to People Living with AIDS (PLWA) and other vulnerable groups}

Care and support to PLWA continued to receive more attention. In order to facilitate the nutritional status of PLWHA on ARV, CNLS negotiated with WFP, FAO and UNICEF. The community-based approach was strengthened to facilitate home-based care, now that more PLWA have joined the associations; there are more than 600 associations of people living with AIDS.

Poverty Reduction and gender mainstreaming was considered to be an important strategy in the battle against HIV/AIDS. 1010 women and girls' associations have been created in this endeavour, of which 90 percent of projects funds went to women's associations. 
Orphans and Vulnerable Children (OVCs) have been supported to continue with education. For instance, in 2004 PEPFAR and the Multicountry AIDS Programme (MAP) assisted a total of 6270 orphans to get a complete set of school uniforms and other scholastic materials. MAP also financed some 15000 OVCs and helped about 2500 households to have access to the mutuelle health insurance scheme.

Details of the integration of HIV/AIDS strategies across sectors are given in Table 8.1 below.

\section{Table 8.1 Integration of HIV/AIDS Strategies across sectors}

\begin{tabular}{|c|c|c|}
\hline Sector & $\begin{array}{l}\text { Key } \\
\text { Partners }\end{array}$ & Current Progress in integration \\
\hline Agriculture & MINAGRI & $\begin{array}{l}\text {-Trained } 49 \text { representatives of institutions of MINAGRI in IEC/BCC } \\
\text { communications. } \\
\text {-Carried out an awareness raising campaign for } 200 \text { staff, and provided VCT to } \\
220 \text {. } \\
\text {-Distributed over } 21,000 \text { condoms within the ministry. } \\
\text {-Carried out } 11 \text { supervision visits. } \\
\text {-Trained } 51 \text { peer educators. } \\
\text {-Held an activity coordination meeting attended by } 44 \text { representatives from } \\
\text { ministry's institutions.(Programme fund worth } 40,490,210)\end{array}$ \\
\hline Infrastructure & MININFRA & $\begin{array}{l}\text {-Institutional support (infrastructure) to health facilities to accommodate } \\
\text { HIV/AIDS care and treatment }\end{array}$ \\
\hline Health & MINISANTE & $\begin{array}{l}\text { TRAC: } 100 \text { ToT were trained on the integrated package of } \\
\text { PMTCT/VCT/OI/STI . } 153 \text { were trained on the integrated package, } 95 \text { had } \\
\text { training on the PMTCT/VCT module. } 14 \text { health personnel trained on ARV } \\
\text { treatment. } 37 \text { VCTI sites and } 7 \text { ARV sites were supervised. IEC materials and } \\
\text { training modules were developed on ARV, VCTI, opportunistic infections and } \\
\text { sexually transmitted infections. Drugs provided for the management of } \\
\text { opportunistic infections and STI. } \\
\text { LNR: In addition to the quality control of } 20,042 \text { HIV samples and } 34,000 \text { CD4 } \\
\text { tests from the VCTI sites, } 2 \text { staff laboratory personnel were trained abroad on } \\
\text { the biological follow up of patients on ARV, and the management and quality } \\
\text { control of CD4 and viral load tests. The laboratory was provided with office } \\
\text { materials and equipment; and it managed to supervise } 38 \text { sites. } \\
\text { Project San Francisco (PSF): the project financed the training of one doctor and } \\
\text { one nurse on the management of HIV/AIDS using ARVs. It also provided PSF } \\
\text { with antiretroviral drugs and nutritional support. } \\
\text {-59 new integrated VCT were created, and } 5 \text { new centre for provision of ARV. } \\
\text { The new sites are (CS Gahanga, CS Rilima, CS Kabuga, CS Munyaga et CS } \\
\text { Rwankuba) .Number of PLWA on ARVs in the country raised to 8991. } \\
\text {-The National Referral Laboratory (NRL) now fully operational, overseeing } \\
\text { quality assurance of other laboratories. The number of CD4 tests done by the } \\
\text { NRL increased from } 13,000 \text { (2002) to } 15,000 \text { (2003) to } 34,000 \text { (2004), TRAC } \\
\text { has more scaled-up Sentinel surveillance sites in ANC, with a pilot of } \\
\text { TRACnet. } \\
\text {-Two important studies DHS + ( } 2004 \text { incorporating HIV testing ) and PLACE } \\
\text { (people socializing in high-risk sites ) both started in } 2004 \text { to be complete in } \\
2005\end{array}$ \\
\hline Education & MINEDUC & $\begin{array}{l}\text {-Prevention programmes in Schools (Life Skills and peer Education). } \\
\text {-Adolescent Reproductive Health programmes }\end{array}$ \\
\hline
\end{tabular}




\begin{tabular}{|c|c|c|}
\hline & & $\begin{array}{l}\text { LUCS (UNR) Butare: } \\
-99,000 \text { condoms distributed to 7,000 university students. } \\
-2 \text { Radio messages passed every month on HIV/AIDS, BCC, unwanted } \\
\text { pregnancies and provoked abortion. } \\
-10 \text { students visited TASO in Uganda on a fact finding mission. } \\
\text {-1 student representative participated in training on operational planning and } \\
\text { project control in Morocco. } \\
\text { KHI (Kigali Health Institute): } \\
\text {-Sensitization of } 14,069 \text { prison inmates on VCT in } 4 \text { prisons. } \\
-670 \text { trained in VCT counselling (pre \& post test counselling). } \\
-8,056 \text { prison inmates tested voluntarily. (Programmes fund worth } 123,056,370 \\
\text { RwF) }\end{array}$ \\
\hline $\begin{array}{l}\text { Human } \\
\text { Resources and } \\
\text { Capacity } \\
\text { Building }\end{array}$ & MIFOTRA & $\begin{array}{l}\text {-Put In place Focal Points and building their capacity to plan for HIV/AIDS } \\
\text { activities. } \\
\text {-On-the-Job and long term training of health personnel in care and treatment of } \\
\text { HIV/AIDS and related diseases, training in planning and coordination, } \\
\text { monitoring and evaluation of HIV/AIDS programmes and financial } \\
\text { management. }\end{array}$ \\
\hline Private Sector & MINICOM & $\begin{array}{l}\text { - In total, } 27 \text { civil society organizations have received MAP funding, with a } 189 \\
\text { sub-project. (In total 746,982,672 RwF have been awarded to PLWHA, OVCs } \\
\text { and community groups) } \\
\text {-Institutional Capacity Development and reinforcement of the role of APELAS } \\
\text { in coordinating the activities of fight against HIV/AIDS in the private sector } \\
\text {-Financial support to APELAS, ATRACO, CNJR, CARITAS, NGO Forum, } \\
\text { Pamasor, ASOFERWA, Rwanda Women Net work, Barakabaho, Ejo } \\
\text { Nzamerante, ARBEF, AESD to implement HIV/AIDS programmes } \\
\text { ATRACO (association of transport workers) were integrated with the following } \\
\text { activities: monthly IEC sessions in all } 12 \text { bus stations in Rwanda to reach basic } \\
\text { messages about AIDS, condom demonstration sessions, and to stimulate } \\
\text { demand for VCT services. These sessions touched roughly } 12,000 \text { passengers, } \\
\text { passers-by, conductors and drivers. Transmitted basic messages on AIDS at } 2 \\
\text { sport competitions in Butare and Gisenyi, which produced a waiting list of } \\
\text { close to } 8,000 \text { individuals who expressed interest in being tested. Carried out } 4 \\
\text { campaigns against stigma and discrimination in the bus stations of Cyangugu, } \\
\text { Gikongoro, Rwamanagana and Karenge with a capacity close to } 6,500 \text { people. } \\
\text { Trained } 60 \text { focal point members of ATRACO in IEC/BCC and in income } \\
\text { generating activities. Carried out } 144 \text { awareness raising/IEC/BCC activities in } \\
\text { bus station nationwide with a capacity cloud of roughly } 7000 \text { people. Organized } \\
\text { study tour for } 15 \text { members of ATRACO to TASO (Uganda). Distributed about } \\
160,000 \text { condoms in bus stations nationwide. Organized VCT for } 6,402 \\
\text { persons. } 108 \text { films projected in taxi parks that attracted 10,800 people. Produced } \\
600 \text { T-shirts with a message on HIV/AIDS for World's AIDS Day celebrations. }\end{array}$ \\
\hline $\begin{array}{l}\text { Governance } \\
\text { and } \\
\text { Decentralisatio } \\
n\end{array}$ & MINALOC & $\begin{array}{l}\text {-Reinforcement of Decentralisation of Coordination structures to Provinces } \\
\text { (CPLS) and District (CDLS) Levels } \\
\text { (activities include: establishment of over } 400 \text { anti AIDS clubs, reaching roughly } \\
8,000 \text { youth representatives, training of about } 1,078 \text { peer educators, training of } \\
\text { roughly } 500 \text { associations of PLWHA in the preparation of sub-projects; training } \\
\text { of over } 1,211 \text { commercial sex workers; mobilization of about } 1,570 \text { local } \\
\text { administrative and religious leaders, } 720 \text { members of CPLS/CDLS and training } \\
\text { of about 2,300 representatives of women's organizations). } \\
\text {-Carried out a rapid assessment of the educational needs of orphans and } \\
\text { vulnerable children (OVCs) in three target provinces (Butare, Cyangugu, } \\
\text { Umutara), } \\
\text {-At province level activities were largely the prevention and small income- } \\
\text { generating activities. MAP project financed the activities in the provinces as }\end{array}$ \\
\hline
\end{tabular}




\begin{tabular}{|c|c|c|}
\hline & & $\begin{array}{l}\text { follows: Gitarama 56,564,750Frw, Cyangugu50,164,500Fr, Byumba } \\
\text { 53,721,250Frw, Kigali City 94,568,950, Umutara 55,924,950Frw, Gisenyi } \\
\text { 53,921,600Fr, Ruhengeri 45,477,800Fr, KigaliNgali 54,677,600Fr, Gikongoro } \\
\text { 44,032,700Frw. } \\
\text {--Carried out } 6 \text { supervision visits to each of the } 3 \text { provinces to inform them of } \\
\text { the project and to initiate preparation of project supported activities. } \\
\text {-Assisted some } 15000 \text { OVCs ( environ } 2500 \text { ménages) in the three MAP } \\
\text { provinces to have access to the mutuelles } \\
\text {-Assisted in the construction/rehabilitation of housing for } 30 \text { child - headed } \\
\text { households } \\
\text {-Orphan vulnerable children (OVC) were assisted to access education. These } \\
\text { include } 4,800 \text { by PEPFAR, } 1470 \text { by MAP; receiving a complete set of school } \\
\text { uniforms and other scholastic materials. MAP assisted also some } 15000 \text { OVCs } \\
\text { ( about } 2500 \mathrm{HH} \text { ) to have access to the mutuelles. } \\
\text {-Provided vocational training for some } 500 \text { child headed households: } 20 \text { per } \\
\text { district for } 25 \text { districts. }\end{array}$ \\
\hline \multirow[t]{2}{*}{ Other areas } & $\begin{array}{l}\text { NATIONAL } \\
\text { POLICE }\end{array}$ & $\begin{array}{l}\text {-Organized } 5 \text { VCT campaigns for some } 4000 \text { policemen and their families, of } \\
\text { which roughly 2,000 were tested. } \\
\text {-Distribute } 450,000 \text { condoms within the ranks of the police force. } \\
\text {-Trained } 30 \text { policemen in IEC/BCC. Trained } 140 \text { peer educators in IEC/BCC } \\
\text { techniques. } \\
\text {-Established } 6 \text { anti AIDS clubs with a membership of } 180 \text { police men.( } \\
\text { Programme funds worth } 102,953,600 \mathrm{Fr})\end{array}$ \\
\hline & MINADEF & $\begin{array}{l}\text {-Carried out } 12 \text { awareness raising campaigns for } 12,000 \text { soldiers in Gisenyi, } \\
\text { Kibuye, Rugengeri, Butare, Gikongoro, Cyangugu. } \\
\text {-Organized } 12 \text { training sessions in behavioural change communications (BCC) } \\
\text { for } 375 \text { participants in Butare and Gikongoro. } \\
\text {-Trained } 14 \text { lab technicians to strengthen STI screening and diagnosis and HIV } \\
\text { testing. } \\
\text {-Initiated process of rehabilitating VCT services sites in } 7 \text { out of the country's } \\
12 \text { provinces. } \\
\text {-3.4 million condoms have been procured and distributed in the army. } \\
\text {-Procured audio visual material for the VCT services } \\
\text {-Organized } 7 \text { supervision missions in } 12 \text { brigades. } \\
\text {-Trained } 46 \text { counsellors in provision of VCT. } \\
\text {-Provided HIV testing } 3,293 \text { persons at Kanombe Military Hospital (Integration } \\
\text { programme worth } 158,269,250 \text { Frw) }\end{array}$ \\
\hline
\end{tabular}

The objectives of CNLS are shown in Annex 18, however these relate to the period 2002-2006 and were developed when the HIV prevalence rate was estimated at $13 \%$. A new strategic framework for 2005-2009 is currently being developed and will be finalized by the end of 2005 


\section{Human Development - Education}

\subsection{Introduction}

The Government of Rwanda considers education as a fundamental human right and an essential means to ensure all Rwandans realize their full potential. It places special emphasis on basic education as a priority area within the PRSP because of the strong correlation between basic education, improved economic opportunities, better health, and fewer children especially for girls. The Government is committed to internationally agreed targets such as Education For All (EFA) and the Millennium Development Goals - improved primary completion rates by 2015 and gender equity in education by 2005 .

It is important to address the issue of education and training through its availability and affordability as far as access is concerned. Schools must be built and nobody must be denied their right to education because she or he can not pay for it. Acceptability and adaptability are also important as far as quality is concerned. In addition the issues of efficiency, effectiveness and equity of the education system must be of concern.

MINEDUC holds Joint Reviews of the Education Sector (JRES) annually in April/May. The JRES forms the basis of PRS Progress Reports, including this particular 2004/2005 report and aims to monitor progress of the sector, to set up further strategies and to improve donor coordination. It should be noted that for this year, little new information on indicators is available because of the change in the school year. 
9.2 Key performance Indicators in Education and Training

\begin{tabular}{|c|c|c|c|c|c|}
\hline & $2002 / 03$ & $2003 / 04$ & $\begin{array}{l}2005 \\
\text { targets }\end{array}$ & $\begin{array}{l}2006 \\
\text { targets }\end{array}$ & $\begin{array}{l}2007 \\
\text { targets }\end{array}$ \\
\hline \multicolumn{6}{|l|}{ Input Indicators } \\
\hline $\begin{array}{l}\text { Government spending on } \\
\text { education as \% of total public } \\
\text { expenditure }\end{array}$ & 23.7 & 23.0 & 22.0 & 24.4 & 25.2 \\
\hline $\begin{array}{l}\text { Public expenditure on primary } \\
\text { education as } \% \text { of total public } \\
\text { expenditure on education }\end{array}$ & - & 41.7 & 42.0 & 42.7 & 43.2 \\
\hline $\begin{array}{l}\text { Ratio of higher education to } \\
\text { primary education unit costs }\end{array}$ & 89 & 86 & 77 & 74 & 68 \\
\hline \multicolumn{6}{|l|}{ Output Indicators } \\
\hline $\begin{array}{l}\text { Pupil : teacher ratio (at } \\
\text { primary) }\end{array}$ & 65.8 & 66.9 & 64 & 61 & 58 \\
\hline $\begin{array}{l}\text { Non-salary recur spending as a } \\
\% \text { of recur spending for } \\
\text { primary education }\end{array}$ & - & 21.0 & 26.0 & 28.0 & 30.0 \\
\hline Number of teachers in Primary & 27,319 & 28,774 & 30,113 & 31,404 & 33,005 \\
\hline $\begin{array}{l}\text { Number of teachers in Tronc } \\
\text { Commun }\end{array}$ & $2,343(\mathrm{e})$ & $2,600(\mathrm{e})$ & 2,868 & 3,175 & 3,458 \\
\hline $\begin{array}{l}\text { Number of teachers in Upper } \\
\text { Secondary }\end{array}$ & 1,299 & 1,442 & 1,576 & 1,650 & 1,764 \\
\hline \multicolumn{6}{|l|}{$\begin{array}{l}\text { Outcome Indicators (primary } \\
\text { education) }\end{array}$} \\
\hline Gross enrolment rate $(\%)$ & 128.4 & 130.8 & 129 & 125 & 123 \\
\hline Net enrolment rate $(\%)$ & 91.2 & 93.0 & 94 & 95 & 96.3 \\
\hline NER Boys & 90.1 & 91.5 & & & \\
\hline NER Girls & 92.4 & 94.5 & & & \\
\hline Completion rate (\%) & 38.1 & 44.9 & 46 & 51 & 56 \\
\hline Average repetition rate (\%) & 20.6 & $20(\mathrm{e})$ & 18 & 16 & 14 \\
\hline Average drop out rate (\%) & 15.2 & 16 & 14 & 12 & 9 \\
\hline Transition to second (\%) & 45 & 47 & 48 & - & - \\
\hline $\begin{array}{l}\text { Ratio of students to qualified } \\
\text { teachers }\end{array}$ & 70.3 & 75.8 & 64 & 61 & - \\
\hline
\end{tabular}

(e) - estimated, exact data not available

\subsection{Priority Delivery Areas}

\subsubsection{Early Childhood Care and Development (ECCD)}

Access to ECCD is an important factor in increasing retention and achievement in subsequent levels of education. It is also an enabling factor in supporting girls to attend school regularly rather than caring for young siblings and giving mothers time to participate in poverty 
reduction activities (Gender, Education and Poverty Review, MINEDUC 2003). In 2004 efforts were made including sensitisation of parents to take their children to ECCD centres. Training was given to ECCD centres in Ruhengeri, Gisenyi, Kibuye and Kibungo provinces. The development of an ECCD policy has started. However, the challenge still remains that few children can access this education.

\subsubsection{Primary Education}

The NER at primary level in Rwanda has increased from $73.3 \%$ for $2001 / 02$ to $93.0 \%$ for $2003 / 04$, implying that even most of the poorest households are now able to send their children to school. However, the primary completion rate for 2004 is only $44.9 \%$ while the transition rate to secondary stands at $47 \%$. The repetition rate is still estimated at around $20 \%$ with a drop out rate of $15.2 \%$. The agreed targets are to attain Universal Primary Education by 2010 and Education For All by 2015. This needs deliberate actions to address internal inefficiency. Another major challenge is achieving these goals without compromising quality.

The new policy on Fee-Free Primary Education - abolishing school fees of FRW 300 per child per year and substituting with a capitation grant - continued to increase enrolment last year. However this created an 'access shock' in some places.

\section{Achievements}

- Fee free primary education and government capitation grant raised from FRW 300 to FRW 1000 per pupil per year in the 2005 budget

- 9-year basic education framework developed aims to improve completion rates

- Decentralisation process on course

- Training of teachers and provision of STE books in catch-up centres

- Construction of 863 classrooms

- School feeding in 200 schools catering for 180,028 pupils

- Training 655 teachers in different subjects

- Several curricula revised and books supplied

\section{Challenges}

$\circ$ Increased financial demands

- Increased wage bill for teachers

- Supply of textbooks to all primary schools in all subjects

○ Construction of more classrooms to cater for the access shock

\subsubsection{Secondary Education}

Secondary education is important in terms of its links to longer-term strategies for poverty reduction and human resources development. The government has decided that the first 3 years of secondary education be part of basic education. This is an important decision for poverty reduction. The nine year basic education policy seeks to:

- Increase P6 completion rate to above $75 \%$ by 2015

- Increase transition rate from grade 6 to grade 7 to above $75 \%$

- Improve quality at all levels through: reduction in double shift in primary grade 1-3, teacher training and motivation, provision of teaching learning materials especially books etc 
Nationally, the proportion of girls attending secondary education is only slightly lower than that of boys (48.04\% against 51.96\%). However, there are differences in equity in terms of school-type and by region. Fewer girls access public secondary schools (about 32\%) as compared to $68 \%$ of boys attending public schools. Yet public schools are far better resourced than private secondary schools where $60 \%$ of the girls find themselves. This raises the issue of a continuing education gap between boys and girls with implications for inequality in career opportunities.

In October 2003, MINEDUC opened, in various districts throughout the country, 94 new lower secondary schools, admitting 8,648 students. In 200558 more secondary schools were opened admitting 5,336 more students. Also 58 private schools signed contracts with MINEDUC to admit S1 students who passed but could not get places in government schools. This has contributed to an increase in access to secondary school opportunities and consequently the transition rate from primary to secondary has noticeably increased.

\section{Achievements}

- A 9-year basic education framework developed

- More lower secondary schools established

- Training of teachers: 333 in sciences, 90 in ICT, 33 in pedagogic activities

- Construction of 180 classrooms, rehabilitating 6 TTCs and expansion of 5 schools to centres of excellence

- Revision of several curricula and supply of books

Challenges

- Continued low transition rate to secondary schools

- Inadequate supply of educational materials

- Low quality and motivation among teachers

\subsubsection{Tertiary Education}

During 2004 Parliament passed the Higher Education Bill and a law to establish a National Council for Higher Education. These two policies will help in the governance of Higher Education. A study on Higher Learning Institutions' capacity building, including an exit strategy for expatriate teachers, is being carried out.

\section{Achievements}

$\circ$ Higher Education and NCHE bills passed by Parliament

- Number of students in the 6 HLIs increased from 12,211 (2002/2003) to 14,456 $(2004 / 2005)$

- Number of female students in HLIs increased from 26.8\% (2002/2003) to $29.3 \%$ $(2003 / 2004)$

- SFAR being strengthened

Challenges

- Cost of expansion

- Continued high cost of expatriate staff and need for development of local staff 


\subsubsection{Science and Technology}

A draft policy for science and technology education is being developed and will be presented at a conference of top policy makers and education experts in May 2005 for the purpose of ratification. The ICT programme in schools was started in 2004 with some primary and secondary schools being supplied with computers. Computer connectivity has been developed in some secondary schools. Use of ICT is compulsory for all students in Higher Learning Institutions. KIST, with support from RITA, has continued to provide training in ICT to different beneficiaries including secondary school teachers.

Achievements

- Draft policy for Science and Technology in place

- Computers being supplied to primary and secondary schools

- Computer connectivity being undertaken in secondary schools

\section{Challenges}

- Use of computers still at infant stage due to lack of connectivity and trained teachers

- Only a few schools supplied with computers

\subsubsection{Technical Education and Vocational Training (TEVT)}

TEVT is considered an important element in poverty reduction as it provides the critical development skills needed in industrial and other specialised services sectors. The medium term strategy is to have one technical school in each province and a vocational training centre in each district.

The TEVT policy and its costed strategy have been approved by the ministry. A concept document on an integrated primary and secondary programme for the teaching of science and TEVT has been developed. Although availability of resources is still a constraint, consultations have been made since 2004 to mobilise resources to implement the programme and some development partners have already shown interest.

\subsubsection{Non-Formal Education}

The PRSP considers youth and adult literacy, especially for girls and women, a critical development priority. In 2004, a study on policy options for Non-formal education in Rwanda was developed and discussed. The draft policy will be presented to GoR for approval. However, resources for the implementation of the policy are not currently available.

\subsubsection{Girls Education}

In terms of access, there is no difference between girls' and boys participation at the primary and secondary levels of education. Girls and women's access to higher education has been greatly enhanced by private sector institutions. However, the challenge remains the continued gaps in performance and achievement, particularly in mathematics, science and technological fields.

In December 2004, a National Conference on the planning of Girls' Education was held in Kigali. Different strategies were developed and a National Task Force, with representatives 
from different stakeholders, established by MINEDUC. The process of developing a national policy on Girls Education was also started.

Achievements

- Consensus among stakeholders on key strategies for the promotion of girls education reached

\section{Challenges \\ - Inadequate supply of science equipment \\ - Shortage of qualified science and technical teachers}

\subsection{Planning, Management and Financing}

\subsubsection{Planning and Management}

Proper planning and management of education guarantees effective and efficient delivery of education and training. Through effective delivery of education, we can realize the intended outcomes and impact of education. Through efficient delivery of education we can realize the same products using minimum resources. MINEDUC has continued using a Sector Wide Approach (SWAP) in getting more partners on board. A long-term strategy and Financial Framework (LTSFF) 2004-2015 was developed. Both the 2005-2010 ESSP and 2005-2007 MTEF are developed in line with this framework.

The 9-year basic education policy options have been developed, after four studies carried out in 2004 to provide a basis for policy formulation. These policy options and their financial implications have been simulated to 2015. Decision on the best option will be taken soon.

Other concrete issues undertaken to improve planning and management include:

- Training of all 106 district education inspectors in strategic planning, MTEF and carte solaria

- Training of 2000 members of PTAs

- Construction of 12 education offices, one in each province

\subsubsection{Public expenditure on education}

The Government of Rwanda recognises the importance of education and training in poverty reduction and has tried to allocate a reasonable proportion of its budget to education. However while trying to protect the allocation to primary education of $50 \%$ of the education budget to meet EFA 2015, the remaining sub-sectors such as Technical Education, Science and Technology, Non-formal, Higher Education, etc are left with inadequate resources to realize their set objectives. Table 9.1 below shows budget and expenditure on education by sub-sector. 
Table 9.1 Budget and Expenditure on Education Sector by Sub-sector

\begin{tabular}{|l|r|r|r|r|}
\hline Programme & $\begin{array}{r}\text { Budget (in } \\
\text { billions) }\end{array}$ & $\begin{array}{r}\text { \% of total } \\
\text { budget }\end{array}$ & $\begin{array}{r}\text { Expenditures (in } \\
\text { RWF billions) }\end{array}$ & $\begin{array}{r}\text { Budget } \\
\text { Execution in \% }\end{array}$ \\
\hline Primary Education & 16635.9 & 41.7 & 17519.2 & 105.3 \\
\hline Secondary Education & 8189.2 & 20.5 & 7170.9 & 87.6 \\
\hline Higher Education & 11761.8 & 29.5 & 14168.7 & 120.5 \\
\hline STR & 722.8 & 1.8 & 668.6 & 92.5 \\
\hline ENF & 377.9 & 0.9 & 149.2 & 39.5 \\
\hline Institutional Support & 2189.5 & 5.5 & 2137.1 & 97.6 \\
\hline Total & $39,877.1$ & 100.0 & $41,813.7$ & 104.9 \\
\hline
\end{tabular}

Efforts are being made to mobilise more resources as well as efficient use of the existing resources. Some of the strategies include cost sharing in HLIs and community participation for primary and secondary education

\subsubsection{Monitoring and Evaluation (M\&E)}

A long-term strategy and financial framework for M\&E has been developed. Key performance indicators were presented at the beginning of this chapter. Decentralised levels up to schools have been advised on using their strategic plans to develop their indicators in line with those at the national level. The JRES provides a wider forum for monitoring and evaluation. MINEDUC uses its Annual Statistics results, reports from the General Inspectorate as major monitoring and evaluation instruments. Also several studies have been carried out to inform policy planning and management of the system. Challenges remaining include further development of the EMIS and limited resources for some key areas. 


\section{Human Development - Water and Sanitation}

\subsection{Introduction}

Investment in drinking water supply is perceived as a high priority intervention area at district levels. Reducing the average distance to a source of drinking water frees up time for women and girls in particular, allowing girls to profit equally from the nine year basic education programme compared to boys, and freeing up time for women to engage in productive activities. Increasing the amount of water used on a per capita basis will evidently also have a dramatic positive impact on the general health status of the population.

The overall objective of the water and sanitation sector is to improve the living condition of the population through the optimal use of water resources and access to sanitation services for all. Specific objectives and performance indicators are summarised in the table below:

\subsection{Key objectives and performance indicators for Water and Sanitation}

\begin{tabular}{|l|l|}
\hline Objectives & Indicator \\
\hline Integrated and & Sector policy updated and adopted \\
sustainable & MTEF adopted \\
management of & Sector strategy elaborated \\
water resources & Inventory of water supply infrastructure realised \\
\hline $\begin{array}{l}\text { Increase access to } \\
\text { safe water and } \\
\text { sanitation services }\end{array}$ & $\begin{array}{l}\text { Effective access to safe drinking water in rural areas increased } \\
\text { from about 41\% of the population in 2001 to 45.75\% in 2004. } \\
\text { Reduction of water losses in the city of Kigali to 20\% in 2004 }\end{array}$ \\
\hline $\begin{array}{l}\text { Intensify Hygiene } \\
\text { Education and } \\
\text { Sanitation }\end{array}$ & $\begin{array}{l}\text { Development of standardised contracts, plans, and unit costs } \\
\text { for latrines and water tanks } \\
\text { Training and elaboration of manuals }\end{array}$ \\
\hline
\end{tabular}

\subsection{Progress assessment}

The Water and Sanitation policy that was adopted in 2004 envisages a dynamic approach with responsibilities delegated to communities and districts. It restricts the focus of the central government to planning, regulation, promotion, monitoring and oversight. Decision making is decentralized with active community participation at all stages of the project cycle to ensure a demand driven approach. The intervention of all actors (formal or informal private sector, NGOs) to strengthen capacities and fill physical and human capital gaps is highly encouraged.

In the domain of integrated and sustainable management of water resources, the water sector policy was updated and a new sector strategy was elaborated in 2004. These were accompanied by investment programmes for water and sanitation in rural areas and the city of Kigali. 
Studies were also launched to update the legal framework and to evaluate the use of water in other economic sectors. Finally, an information centre was created that is accessible to users.

To increase access to safe water and sanitation services, promotion activities have been carried out to encourage private sector participation in the water sector, and a diagnostic study was undertaken on water management. A large number of projects have been completed or continued ongoing work to construct, rehabilitate, or extend water infrastructure. These infrastructures benefit an estimated 500 thousand persons, which (based on 2001 estimations) should have increased the overall access rate to safe drinking water to $45.75 \%$ in 2004 , up from $41 \%$ in 2001 . Many new projects have been launched or were identified. Electrogaz managed to reduce technical water losses in Kibuye and Kigali.

Regarding the intensification of hygiene and sanitation education, standardised contracts, plans, and unit costs have been developed for latrines and water tanks. Moreover, 84 teachers were trained in managing hydraulic installations and 500 manuals were distributed to train borehole makers. Manuals have also been provided on the subject of appropriate water and sanitation technologies for schools and communities and over 2000 health guides were distributed. At the ministry, 24 staff were trained in different aspects of water management.

The PETS carried out in 2004 recommended further research into the appropriate pricing of water services since a high price has a negative effect on the impact of the project on the beneficiaries.

Little information on sanitation is available. A survey to assess the status of water and sanitation facilities in primary schools in six provinces conducted by Kigali Health Institute in October 2003 found that 44 per cent of pupils did not have access to water in schools. Latrines were present in 98 per cent of schools, though only in 14 per cent of the cases were there separate latrines for boys and girls. Half the schools reported separate latrines for students and teachers. Cleanliness of toilets was generally found to be very poor. 


\subsection{Budget execution}

Budget execution figures for 2004 are displayed in the tables below. A low execution rate for the rainwater programme was caused by a lack of specific projects that could be identified. The water supply project in Butare was well executed although there were some delays in the disbursement of external funds. Other externally funded projects suffered from lengthy tendering procedures (water supply Bugesera karenge) and delays in signing the project agreement (water supply Gikongoro).

\begin{tabular}{|c|c|c|c|c|}
\hline \multirow{2}{*}{\multicolumn{2}{|c|}{$\begin{array}{l}\text { Type } \\
\text { Recurrent Budget }\end{array}$}} & Budget & Execuction & Exec. Rate \\
\hline & & 173203992 & 148262617 & $85,6 \%$ \\
\hline \multicolumn{5}{|l|}{ Development Budget- internal funds } \\
\hline \multicolumn{2}{|l|}{ Gestion Intégré des Ressources en Eau } & 10004418 & 1004418 & $100 \%$ \\
\hline \multicolumn{2}{|l|}{ AEP Mukingi } & 150000000 & 149995892 & $99,9 \%$ \\
\hline \multicolumn{2}{|l|}{ AEP ville Butare } & 156327600 & 154200974 & $98,6 \%$ \\
\hline \multicolumn{2}{|l|}{ Utilisation de l'eau de pluie } & 30000000 & 18212902 & $60 \%$ \\
\hline \multicolumn{2}{|l|}{ AEP Gabiro } & 70000000 & 45000000 & $75 \%$ \\
\hline \multicolumn{2}{|l|}{ Rural Water Supply and sanitation } & 87700000 & 87700000 & $100 \%$ \\
\hline \multicolumn{2}{|l|}{ S/T Budget de Développement } & 495032018 & 481114186 & $97 \%$ \\
\hline \multicolumn{2}{|l|}{ Total Budget 2004} & 668236010 & 629376803 & $94,2 \%$ \\
\hline \multicolumn{4}{|c|}{ Development Budget - external financing Externes } & \\
\hline Project & Donor & $\begin{array}{l}\text { Planned } \\
\text { USD }\end{array}$ & \begin{tabular}{|l} 
Executed \\
USD \\
\end{tabular} & Taux en $\%$ \\
\hline Gestion Intègre de Ressource en Eau & JAPON & 999150 & 51198 & 5 \\
\hline WES & UNICEF & 52351 & 52351 & 100 \\
\hline AEP ville de Butare & BADEA & 2264328 & 1333083 & 58,87 \\
\hline AEP Bugesera karenge & UE & 2418228 & 0 & 0 \\
\hline PEAMR & IDA & 1502755 & 1544732 & 102 \\
\hline 8 Ex communes & RFA & 743343 & 743343 & 100 \\
\hline AEP petit centre de Gikongoro & Autriche & 875643 & 0 & 0 \\
\hline Total external financing 2004 & & 8855798 & 3724707 & 42 \\
\hline
\end{tabular}




\section{Capacity Building and Human Resource Development}

\subsection{Introduction}

Unfolding public sector reforms and their implementation have exerted new and greater demands for capacity building in the country. More than ever before, the country's development agenda will depend on the available human resource and institutional capacity to manage the reforms, implement policies and monitor and evaluate their outcomes.

The Ministry of Public Service, Skills Development and Labour (MIFOTRA) is responsible for creating an efficient, effective and accountable public service capable of spearheading the development process. It has been leading the process of Public Service Reform in Rwanda and has set up the Human Resource and Institutional Development Agency (HIDA) to coordinate and carry out oversight of the Multi-sector Capacity Building Programme in the country.

\subsection{Overview of Sectoral Strategy}

All policies in line with capacity building and human resource development since July 2004 have been guided by the current Sector Strategy and the Medium Term Expenditure Framework. The current sector strategy is to have an effective public service with competent and motivated employees, laws and regulations tailored to the present and future context, a modern system of human resource management, clearly defined and disseminated policies on labour administration and an appropriate environment for promoting decent work for all, employment and job creation. The key objectives of MIFOTRA alongside corresponding performance indicators and progress assessment are set out in Table 11.1 below:

Table 11.1 Key objectives, indicators and progress made in Capacity Building and Human Resource Development

\begin{tabular}{|l|l|l|}
\hline Objective & Indicator & Progress \\
\hline $\begin{array}{l}\text { Enhancing the } \\
\text { effectiveness and } \\
\text { efficiency of } \\
\text { public } \\
\text { administration }\end{array}$ & $\begin{array}{l}\text { All public institutions } \\
\text { restructured in line with the } \\
\text { Public Service Reform } \\
\text { Programme }\end{array}$ & $\begin{array}{l}\text { All Public Service Institutions have been } \\
\text { restructured } \\
\text { The Public Service Reform } \\
\text { Programme implemented }\end{array}$ \\
$\begin{array}{l}\text { Government employees trained } \\
\text { The Public Service Reform Programme has } \\
\text { been implemented in all Ministries, Provinces } \\
\text { and some public institutions } \\
\text { A new performance evaluation } \\
\text { trained abroad and locally respectively in } \\
\text { fields related to their tasks. } \\
\text { Completed }\end{array}$ \\
\hline
\end{tabular}




\begin{tabular}{|c|c|c|}
\hline & $\begin{array}{l}\text { system in the public service } \\
\text { based on effectiveness and } \\
\text { transparency established } \\
\text { A new salary scheme established }\end{array}$ & Completed \\
\hline $\begin{array}{l}\text { Promoting and } \\
\text { supporting skills } \\
\text { development } \\
\text { activities and } \\
\text { initiatives both in } \\
\text { the public and } \\
\text { private sectors }\end{array}$ & $\begin{array}{l}\text { HIDA established } \\
\text { The multi-sector capacity } \\
\text { building programme implimented } \\
\text { Vocational training promoted }\end{array}$ & $\begin{array}{l}\text { HIDA was established on } 31^{\text {st }} \text { Dec } 2004 \\
\text { Implementation of MSCBP started May } 2005 \\
\text { by HIDA } \\
\text { A new youth training centre worth } 75 \text { million } \\
\text { Rwf was built in Musenyi, Mutara Province. } \\
28 \text { Private youth training centres started in } \\
2004 \text {, six of them were approved by } \\
\text { MIFOTRA } \\
\text { In } 2004327 \text { students completed technical } \\
\text { training in electricity, welding, mechanics etc } \\
\text { at Kavumu and } 87 \% \text { are already employed. } \\
\text { Kavumu received a } 1.250 .000 € \text { support from } \\
\text { the Belgium Government to develop Kavumu } \\
\text { into an excellence training centre for skills } \\
\text { development. }\end{array}$ \\
\hline $\begin{array}{l}\text { Improve } \\
\text { geographic } \\
\text { access by } \\
\text { citizens to } \\
\text { Government } \\
\text { services } \\
\text { (decentralization) }\end{array}$ & $\begin{array}{l}\text { The structures of the institutions } \\
\text { revised in line with the tasks } \\
\text { involved and decentralized } \\
\text { Authority and resources } \\
\text { transferred to decentralized units. }\end{array}$ & $\begin{array}{l}\text { Structures of Ministries, Provinces, Districts, } \\
\text { Parastatals, and other public institutions were } \\
\text { revised and where necessary decentralized } \\
\text { (Reform) } \\
\begin{array}{l}\text { Decentralized institutions have autonomy in } \\
\text { executing their work }\end{array}\end{array}$ \\
\hline $\begin{array}{l}\text { Fostering social } \\
\text { dialogue }\end{array}$ & $\begin{array}{l}\text { A National Labour Council } \\
\text { comprising the Government, } \\
\text { Employers Federations and } \\
\text { Employees unions for labour } \\
\text { management established }\end{array}$ & The forum was established in 2005 \\
\hline $\begin{array}{l}\text { Setting up an } \\
\text { appropriate } \\
\text { labour and public } \\
\text { administration } \\
\text { law }\end{array}$ & $\begin{array}{l}\text { A revised labour code approved } \\
\text { A revised public service statute } \\
\text { approved }\end{array}$ & $\begin{array}{l}\text { Not yet approved } \\
\text { Not yet approved }\end{array}$ \\
\hline $\begin{array}{l}\text { Promoting } \\
\text { employment } \\
\text { creation in all } \\
\text { economic sectors }\end{array}$ & $\begin{array}{l}\text { The employment policy finalized } \\
\text { Programmes to promote } \\
\text { employment and }\end{array}$ & $\begin{array}{l}\text { Finalized and awaiting cabinet approval. } \\
\text { A five year youth employment promotion } \\
\text { action plan was initiated and will be finalized }\end{array}$ \\
\hline
\end{tabular}




\begin{tabular}{|l|l|l|}
\hline entrepreneurship initiated & $\begin{array}{l}\text { in June 2005 and thereafter implemented } \\
\text { As regards PDL-HIMO programme 14,142 } \\
\text { jobs were offered in the provinces of } \\
\text { Gikongoro, Kigali Ngali and Umutara in 2004 } \\
\text { CAPMER trained 553 credit agents of Bank } \\
\text { populaires and consultants in partnership with } \\
\text { Rural Sector Support Project and UBPR } \\
\text { CAPMER also trained 27 consulting firms } \\
\text { and CAPER employees in analyzing } \\
\text { bankable investment projects and elaborating } \\
\text { working plans in partnership with FACET BV } \\
\text { atraining firm from Holland. } \\
\text { The reconversion programme saw 250 former } \\
\text { civil servants trained in entrepreneurship } \\
\text { skills by CAPMER. They will now be assisted } \\
\text { in obtaining loans to start up income } \\
\text { generating projects. }\end{array}$ \\
\hline $\begin{array}{l}\text { Providing social } \\
\text { coverage to all } \\
\text { Rwandan citizens }\end{array}$ & $\begin{array}{l}\text { A social security policy put in } \\
\text { place }\end{array}$ & $\begin{array}{l}\text { In progress } \\
\text { The number of workers with } \\
\text { social security increased }\end{array}$ \\
\hline
\end{tabular}

\subsection{Progress assessment}

The progress registered in 2004, based on the MTEF's 2004-2006 targets, was encouraging though significant challenges remain.

This progress assessment focuses on the role of government, though donors have contributed through financing and civil society also played a significant role in the sector. For example, CCOAIB (Conseil de Concentration des Organisations d'Appui aux Initiatives de Base) trained its twenty-nine member NGOs in gender, entrepreneurship, institutional and organization development, leadership and participative monitoring and evaluation.

\subsubsection{Public Service Reform programme}

Regarding enhancement of the effectiveness and efficiency of the public administration, the public service reform programme was implemented in all ministries, provinces and districts in the country focusing on efficiency, decentralization of services and accountability. By the end of 2005 all public institutions will have implemented the programme. So far 1,141 civil servants were retrenched however, with the objective of sustainable skills development for the country, some of those trainable personnel among the retrenchees are benefiting from different programmes organized by the ministry to allow then get absorbed in the country's labour market. 398 were sponsored to further their studies in universities in Rwanda, 250 were trained in entrepreneurship by CAPMER at RIAM Gitarama, 100 are to be trained by RIAM in short programmes that will assist them in obtaining other jobs, 26 are to be trained in hotel and 
tourism management by Rwanda Tourism College and 5 trained in professional driving at Kavumu. Those who remained in service are supposed to have continuous skills development programmes aligned with their job tasks and they will be assisted in effectively performing those tasks. Starting in 2005, RIAM will train top managers and executive officers in the public service, providing them with induction on all government policies, programmes and strategies for vision 2020 and the PRSP. This will facilitate common understanding and improved implementation of the country's development agenda.

\subsubsection{HIDA}

HIDA was established on $31^{\text {st }}$ December 2004 and looks forward to strengthening institutional capacities in light of the changing role of the public sector, to driving more effective service delivery by pursuing decentralization and to fostering a more prominent role of the private sector and civil society through public-private sector partnership.

\subsubsection{Training}

Vocational training was given significant importance in light of its vision of having at least one CFJ (Youth Training Centre) in each district by 2020. In 2004, 28 private CFJs started operating and six were approved by MIFOTRA. A CFJ worth 75 million Rfr was built in Musenyi, Mutara Province (though this is not yet equipped). In Kavumu in 2004, 327 students completed technical training in electricity, welding, mechanics and other skills and $87 \%$ are already employed.

With regard to training and capacity building in 2004, MIFOTRA saw 245 civil servants trained locally in fields related to their tasks and 613 civil service employees were trained abroad. Training was carried out by institutions including KIST, RIAM and the School of Banking and Finance, amongst others.

\subsubsection{Employment Promotion and Job Creation}

In the area of employment promotion and job creation a lot has been achieved. The employment policy was finalized and validated (only remaining to be adapted by the Cabinet), mainly focusing on promoting the youth, women, the public sector, the informal sector and the rural sector. A five year 2005-2010 youth employment promotion action plan was initiated with the support of the UN, World Bank, ILO and other development partners and it is now at its final stage, after which it will be adopted and implemented. PDL-HIMO has already started providing alternative employment to the rural areas and in 200414,142 jobs were offered in the provinces of Gikongoro, Kigali Ngali and Umutara with average earnings of 400 frw per day. Please refer to 
Box 15.1 on page 103 for further details. CAPMER trained 553 credit agents of Bank Populaires and consultants in partnership with Rural Sector Support Project and UBPR. To enhance the ability of Rwandans in developing income generating projects, CAPMER trained 27 consulting firms and CAPMER employees in analyzing bankable investment projects and elaborating working plans in partnership with FACET BV a training firm from Holland.

\section{Table 11.2 Distribution of the labour force.}

\begin{tabular}{|l|r|r|r|r|r|r|r|r|r|}
\hline \multirow{2}{*}{$\begin{array}{l}\text { Economic } \\
\text { Activity }\end{array}$} & \multicolumn{4}{|c|}{ Urban } & \multicolumn{3}{c|}{ Rural } & \multicolumn{3}{c|}{ Total } \\
\cline { 2 - 11 } & Male & \multicolumn{1}{|c|}{ Female } & \multicolumn{1}{c|}{ Total } & \multicolumn{1}{c|}{ Male } & \multicolumn{1}{c|}{ Female } & \multicolumn{1}{c|}{ Total } & \multicolumn{1}{l|}{ Male } & Female & Total \\
\hline Total & 48.6 & 51.4 & 954.237 & 45.5 & 54.5 & 5.111 .196 & 46.0 & 54.0 & 6.065 .433 \\
\hline Employed & 53.4 & 46.6 & 470.706 & 43.2 & 56.8 & 2.916 .763 & 44.7 & 55.3 & 3.387 .469 \\
\hline Unemployed & 62.6 & 37.4 & 10.987 & 63.6 & 36.4 & 4.695 & 62.9 & 37.1 & 15.682 \\
\hline First Job seekers & 51.5 & 48.5 & 7.966 & 53.5 & 46.5 & 6.930 & 52.5 & 47.5 & 14.896 \\
\hline $\begin{array}{l}\text { Economically } \\
\text { Active Population }\end{array}$ & 53.6 & 46.4 & 489.659 & 43.3 & 56.7 & 2.928 .388 & 44.8 & 55.2 & 3.418 .047 \\
\hline House helpers & 28.9 & 71.1 & 109.418 & 46.1 & 53.9 & 652.668 & 43.6 & 56.4 & 762.086 \\
\hline Pupils/ Students & 48.6 & 51.4 & 290.991 & 50.0 & 50.0 & 1.306 .486 & 49.8 & 50.2 & 1.597 .477 \\
\hline Retired Persons & 39.3 & 60.7 & 10.774 & 37.3 & 62.7 & 60.548 & 37.6 & 62.4 & 71.322 \\
\hline $\begin{array}{l}\text { Owners of landed } \\
\text { property }\end{array}$ & 39.1 & 60.9 & 7587 & 41.9 & 58.1 & 23.822 & 41.2 & 58.8 & 31.409 \\
\hline $\begin{array}{l}\text { Persons with no } \\
\text { work }\end{array}$ & 46.1 & 53.9 & 45.808 & 49.4 & 50.6 & 139.284 & 48.6 & 51.4 & 185.092 \\
\hline $\begin{array}{l}\text { Economically } \\
\text { Inactive population }\end{array}$ & 43.4 & 56.6 & 464.578 & 48.4 & 51.6 & 2.182 .808 & 47.5 & 52.5 & 2.647 .386 \\
\hline
\end{tabular}

Source: National Population Census 2002.

\subsection{Challenges for the Sector}

From the analysis above it is clear that a lot of progress has been made. However, proper analysis and evaluation of the sector remains a big challenge. There is no adequate mechanism for harmonizing and coordinating interventions in the sector. Many partners and donors intervene in this sector independently and there is no coordination of their activities. Hence there is an inadequate basis for evaluation.

It is also evident that Rwanda's institutions, especially RIAM, SFB, KIST, CAPMER and Centre Iwacu Kabusunzu, play a big role in capacity building. However, their capacities both human and institutional need to be improved to match demand and the requirement for expertise.

The biggest challenge for the Government also remains: to create a critical mass of trained nationals to fill the skill gaps in the economy, effect changes in management practices and develop and implement policies.

Strategies must be put in place to motivate and retain competent staff, especially in the public service, where improving working conditions and pay constitute a prerequisite for improving public service performance. 


\subsection{Modification of strategies and objectives since 2004.}

Though the vision and overall objectives have not changed, the approach has been modified to reflect progress achieved, arising constraints and new developments in the sector. In particular, HIDA has been established to spearhead development in this sector.

\subsection{Monitoring and evaluation}

Monitoring and evaluation of the sector is done independently by each institution. However, HIDA will take over the coordination role of all institution, while UNDP as the lead donor will take over coordination of the donors.

The PRSP identified cost reduction and increasing access to infrastructure as key components In promoting economic development. Infrastructure development is a key pillar for export promotion and commercial sector development. 


\section{Economic Infrastructure}

\subsection{Transport}

Rural transport links are crucially important to increasing access to markets and underpinning a more general national export promotion strategy. As further elaborated in chapter 14 on Commercial Sector Development, the poor quality of rural roads substantially increases vehicle operating costs and therefore the price of transport services, at the same time as causing damage to agricultural produce.

The responsibility for maintenance and construction of local roads has been decentralized to districts. Districts prepare road plans and negotiate contracts with private enterprises who execute the works. Unfortunately, no aggregated information exists on works carried out at decentralized levels. This section, therefore, reports only on progress achieved at the national level. The key objectives and performance indicators of the transport sector are summarized in Table 12.1.

\section{Table 12.1 Key objectives and indicators for the transport sector}

\begin{tabular}{|c|c|}
\hline Key objectives & Indicators \\
\hline $\begin{array}{l}\text { To open up the } \\
\text { country and reduce } \\
\text { the cost of internal } \\
\text { and international } \\
\text { transport }\end{array}$ & $\begin{array}{l}\text { - Maintenance and rehabilitation of roads and bridges } \\
\text { - Rehabilitation, construction, and technical and economic } \\
\text { feasibility studies for roads, railways, and airports } \\
\text { - Reduction of transport costs through construction of Isaka-Kigali } \\
\text { railway line } \\
\text { - Increase competition in air transport by rehabilitating and } \\
\text { modernising Kanombe International Airport }\end{array}$ \\
\hline $\begin{array}{l}\text { To continue the } \\
\text { liberalization of the } \\
\text { sector and the } \\
\text { modernization of the } \\
\text { Administration }\end{array}$ & $\begin{array}{l}\text { - The private sector will be in charge of completion of works } \\
\text { - A vehicle inspection centre will be functional at end } 2005 \\
\text { - Weighing bridges that have been installed at border posts will be } \\
\text { functional at end } 2006 \\
\text { - A Civil Aviation office was created }\end{array}$ \\
\hline $\begin{array}{l}\text { To support } \\
\text { decentralization for } \\
\text { the development of } \\
\text { the infrastructure of } \\
\text { transport in the rural } \\
\text { zones. }\end{array}$ & $\begin{array}{l}\text { - Maintenance of the secondary and tertiary road network has been } \\
\text { devolved to decentralised entities. } \\
\text { - The common development fund has been operational since } 2002 \\
\text { and finances rural road projects } \\
\text { - The priorities of interventions are determined by the } \\
\text { districts/cities } \\
\text { - A study of reclassification of the road network will start soon }\end{array}$ \\
\hline
\end{tabular}

The fact of being landlocked combined with poor internal road infrastructure is a serious obstacle to the economic development of a country. The following strategies were adopted for the development and the promotion of the transport sector:

- Adoption of coordination measures to set up better organized and structured transport services to correspond with government policy, 
- Pursuit of different ways of opening up the country for greater security of external trade

- The update of legal and regulatory texts governing the transport sector and harmonization of the regulatory texts and standards governing transport at the regional level.

- Creation of service areas on the transport corridors where truck-drivers can relax and equipped with measures for fight against HIV/AIDS,

- Encouragement of the private sector to invest in transport infrastructure

○ Adoption of the HIMO approach for the maintenance of rural roads

\section{Progress made in 2004:}

- Rehabilitation of $141 \mathrm{~km}$ of overland routes, periodic maintenance of $154 \mathrm{~km}$, and routine maintenance of $1500 \mathrm{~km}$, approximately $100 \mathrm{~km}$ road bituminized and 102 bridges built (including 12 on trunk roads and 90 on dirt roads);

- Rehabilitation of Kanombe International Airport is about to be completed

- Rehabilitation studies on $446 \mathrm{~km}$ of tarred roads on the sections Gitarama-Mukamira, Butare-Cyangugu, Cyangugu-Bugarama are completed.

- The following studies are in progress or have been planned: (a) rehabilitation of 589 km Kigali-Ruhengeri-Gisenyi and Butare-Cyangugu, Kigali-Gatuna, Kayonza-Rusumo, Kicukiro-Nyamata-Nemba, Ngororero-Mukamira; (b) the asphalting of $108 \mathrm{~km}$ Ntendezi - Mashyuza-Bugarama, Gisenyi-Kibuye-Cyangugu, (c) the construction of a new modern airport in Bugesera; (d) technical and economic feasibility of the IsakaKigali rail connection.

The constraints met in the implementation of the action plan are primarily the following:

○ Low administrative capacities,

- Lack of clear and coherent policy particularly with regard to the responsibilities for the decentralized entities,

- Low organisational and management capacities in the private sector

- Insufficient financial resources to meet the maintenance and rehabilitation requirements of the stock of transport infrastructures,

- Late adoption of the budget for the Road Maintenance Fund

- Excessively long tendering procedures

- Long procedures in signing external financing agreements

- Legislation which is out of date and provinces which struggle to complete tendering procedures within specified deadlines

With significant progress being achieved in constructing new road infrastructure and rehabilitating old ones, there is a need to shift resources to the maintenance of the existing road network. To this end, MININFRA is in negotiation with development partners to provide direct funding to the Road Maintenance Fund (FER).

\subsection{Energy}

The overall objective of the energy sector is to promote socio-economic development to improve the well being and quality of life of the population through better use of energy 
resources. Specific objectives and performance indicators for the energy sector are summarized in the following table.

\begin{tabular}{|c|c|}
\hline $\begin{array}{l}\text { 1. To increase energy } \\
\text { production to satisfy } \\
\text { demand }\end{array}$ & $\begin{array}{l}\text { - } 23.4 \text { Additional GWh injected into the network in } 2004 \text { (7.8 MW } \\
\text { with Jabana); } \\
\text { - } 16.2 \text { Additional GWh injected into the network in } 2005 \text { (4.5 MW } \\
\text { Gatsata); } \\
\text { - } 216 \text { additional GWh injected into the network in } 2006 \text { (30 MW } \\
\text { Methane Kibuye); } \\
\text { - Electrification Master Plan updated in } 2007 \text {; } \\
\text { - Existing hydroelectric power stations rehabilitated in } 2007 .\end{array}$ \\
\hline $\begin{array}{l}\text { 2. To improve } \\
\text { accessibility to } \\
\text { energy }\end{array}$ & $\begin{array}{l}\text { - Electricity grid and distribution system rehabilitated; } \\
\text { - } 18.5 \mathrm{~km} \text { of line HT110 kV Kibuye-Karongi built in } 2006 ; \\
\text { - } 90 \mathrm{~km} \text { of Kilinda-Gikongoro line and Subdued-Nshili built; } \\
\text { - } 15.5 \mathrm{~km} \text { of line MT Kora-Kalisimbi built in } 2005 \\
\text { - } 71 \mathrm{~km} \text { of MT line } 30 \mathrm{kV} \text { Kigali-Kiyumba built in } 2007 .\end{array}$ \\
\hline $\begin{array}{l}\text { 3. Rational use of } \\
\text { energy resources }\end{array}$ & $\begin{array}{l}\text { - Use of improved stoves in households and institutions to decrease } \\
\text { the consumption of wood-energy. } \\
\text { - Use of alternative energies (Methane, Peat, Biogas etc) in } \\
\text { households and institutions; } \\
\text { - Sensitizing on rational energy management (adoption of } \\
\text { alternative energy sources and energy saving techniques). }\end{array}$ \\
\hline $\begin{array}{l}\text { 4. To promote } \\
\text { accessibility to modern } \\
\text { energy in the rural areas }\end{array}$ & $\begin{array}{l}\text { - Policy of rural energy generation; } \\
\text { - Three (3) Micro power stations built in 2005; } \\
\text { - Three (3) Micro power stations rehabilitated in 2005; }\end{array}$ \\
\hline $\begin{array}{l}5 . \quad \text { To improve } \\
\text { management } \\
\text { sector of energy }\end{array}$ & $\begin{array}{l}\text { - Laws on electricity and Gas available; } \\
\text { - Training plan available } \\
\text { - Staff training of the Sector Energy carried out. }\end{array}$ \\
\hline $\begin{array}{l}6 . \text { Mitigate the } \\
\text { environmental impact } \\
\text { resulting from the } \\
\text { generation and use of } \\
\text { energy. }\end{array}$ & $\begin{array}{l}\text { - Norms and standards available } \\
\text { - Environmental impact studies conducted for all projects }\end{array}$ \\
\hline
\end{tabular}

The energy sector policy was adopted by the Council of Ministers in November 2004. It clearly highlights a number of key problems, such as the deficit in all forms of energy (electricity, Biomass, etc), too high costs of electricity and petroleum products, and environmental impact related to the production and use of energy (deforestation, etc).

The energy policy for rural areas still needs to be approved, though a draft document was elaborated at the end of 2004. This draft document highlights a number of areas where action is needed, such as the construction of micro hydroelectric power stations, use of solar energy, 
construction of a primary distribution network for methane gas for use by households (cooking) and industries (heat) and for the production of electricity (by power generating units) in rural areas. Financing for these activities still needs to be arranged.

In terms of overall energy production, not much progress was made during 2004. In fact, because of reduced rainfall and low water levels, Rwanda underwent an energy crisis without precedent: the production of electricity through the two hydroelectric power stations of Mukungwa and Ntaruka recorded a deficit of 15 MW around March 2004. In light of this situation, the Government implemented an Emergency Action Plan with the following results:

- Installation of Thermal Groups (DGU) with JABANA for an additional 7.8 MW.

- Installation of a Thermal Group with GATSATA for an additional 4.5 MW;

Overall, ELECTROGAS rehabilitated and electrified 56,826 km of electricity lines across the different provinces in the country and during 2004, a combined total of 205.5 GWhof electricity was produced or imported, while $2.0 \mathrm{GWh} / \mathrm{y}$ was exported to neighbouring countries. The number of households served by ELECTROGAS increased by 3,656.

A study on the biomass energy supply ${ }^{8}$ highlighted unsustainable demand for fuelwood and charcoal in 2004 (an $87 \%$ increase in the use of fuelwood and 95\% increase in the use of charcoal were measured in Kigali between 1999 and 2004). Prices of these important sources of fuel have escalated year-on-year, which is likely to have a detrimental effect on the poorest, who are reliant on biomass for their energy source. In fact, biomass is estimated to contribute $95 \%$ of the total supply of energy. With government owned sources insignificant, the study recommended a strategy to produce more (via improved natural forest management, integrating tree planting into farm landscapes), substituting more (using alternative means of producing bricks, which traditionally require a lot of biomass fuel) and saving more (promoting energy efficient cookstoves). In the long-term the study highlighted the need to invest more in renewable energy sources.

As a short term measure, government banned traditional brick making using firewood. Instead, it is proposing to import machines that can produce bricks using soil, cement, and fuel. Accordingly, CDF money would be used to set up a revolving fund which associations at district levels could draw from to finance the purchase of these machines. Considering that over 60 per cent of the population still lives in residences with walls made from mud and wattle, economic development may unleash substantial demand for bricks.

Moreover, during 2004, approximately 40 engineers, technicians and women working in infrastructure management were trained in biogas technology and 3 demonstration units were constructed. Additional activities were undertaken by various partners in the Energy sector, specifically ELECTROGAZ in the electricity sub-sector and IRST in the field of research on biomass-energy.

The Institut de Recherche Scientifique et Technologique (IRST) undertook a number of studies related to the energy sector, most notably on the possibilities of producing biogas from

\footnotetext{
${ }^{8}$ Rwanda Biomass Energy Supply Status - Survey on Charcoal and Fuelwood Supply Chains, Albert Butare and Mike Hughes, October 2004
} 
geranium leaves and sorghum stems; installation of bio-digesters for several institutions and private entities; adapting petrol engines for operation on biogas; construction of several improved stove models that operate on sawdust, wood, peat, or briquettes of various origins; and the pyrolysis of peat.

\section{Table 12.2 Budget execution 2004 related to Energy}

\begin{tabular}{|c|c|c|c|}
\hline & Budget & $\begin{array}{c}\text { Execution } \\
\text { in million RWF }\end{array}$ & Difference \\
\hline Energy & 849.8 & 256.4 & 593.4 \\
\hline Management support & 34.2 & 21.0 & 13.2 \\
\hline Electricity & 12.9 & 3.1 & 9.8 \\
\hline Renewable energy & 2.6 & 0.0 & 2.6 \\
\hline Hydrocarbons & 2.1 & 0.4 & 1.7 \\
\hline Project "ELECTROGAZ Infrastructure Rehabilitation" & 63.7 & 0.0 & 63.7 \\
\hline $\begin{array}{l}\text { Project "ELECTROGAZ Water and Electricity Infrastructure } \\
\text { Rehabilitation Programme" }\end{array}$ & 162.4 & 162.4 & 0.0 \\
\hline Project "Rehabilitation of 3 stations Mukungwa, Gihira et Gisenyi" & 105.0 & 0.0 & 105.0 \\
\hline Project "Study electricity line Gikongoro-Cyanika-Karaba" & 120.0 & 69.6 & 50.4 \\
\hline Project "Electricity line Kibuye-Karongi" & 347.0 & 0.0 & 347.0 \\
\hline Biogas Technical Training Project & 142.2 & 139.2 & 3.0 \\
\hline
\end{tabular}

\subsection{Habitat and Urbanisation}

The key objectives and performance indicators of the habitat and urbanisation sector are summarised in the table below:

\begin{tabular}{|l|l|}
\hline $\begin{array}{l}\text { Realize habitat and town planning in the } \\
\text { context of sustainable development }\end{array}$ & $\begin{array}{l}\text { National habitat policy was adopted and elements } \\
\text { of an urbanization policy were elaborated }\end{array}$ \\
\hline Promote the habitat in the rural areas & $\begin{array}{l}4,467 \text { homeless families were supported in the } \\
\text { construction of housing } \\
\text { Socio-economic investigation into the viability } \\
\text { of imidugudu villages in Butare and Byumba } \\
\text { Provinces } \\
\text { Training in preparation of income generating } \\
\text { projects }\end{array}$ \\
\hline $\begin{array}{l}\text { Create infrastructure and tools for urban } \\
\text { planning in all towns in the country }\end{array}$ & $-\begin{array}{l}\text { Elaboration of Cyangugu Development Master } \\
\text { Plan }\end{array}$ \\
\hline $\begin{array}{l}\text { Provide public institutions with suitable } \\
\text { working space }\end{array}$ & - Construction of a number of public buildings \\
\hline
\end{tabular}


To realise the objectives of the sector, the following strategies were adopted:

- Installation of a legislative and regulatory framework for habitat and town planning

- Creation of new residences for the vulnerable households without shelter

- Development of habitat sites in rural area

- Installation tools for city planning in the cities of the country

○ Reorganization of unplanned districts

During 2004, the text of the National Habitat Policy was brought up to date and a related bill was submitted to Parliament for analysis and adoption. Some first elements of an urbanisation policy were also elaborated.

To promote the habitat in the rural areas, over 100,000 sheets and other building materials were bought and distributed to vulnerable households living in shacks. A total of 4,467 homeless families were assisted in the construction of housing all over the country. Moreover, over three thousand five hundred households that were evicted from Gishwati forest were trained in the preparation of income generating projects. In the provinces of Butare and Byumba, a socio-economic study was undertaken on the viability of imidugudu villages.

In the area of urban planning, a development master plan for the town of Cyangugu was elaborated. Housing development plans were also developed for the Town of Kibuye (250 plots) and Kabuga (100 plots). Moreover, the PIGU (Project d'infrastructures et gestion urbaine) was prepared. This project aims to development urban infrastructure, such as roads and markets.

In terms of providing public institutions with work space, a number of buildings were constructed, including an office for the Province of Umutara, buildings for MINADEF and PRIMATURE, and a building complex to house RRA, OAG, and CNE. Moreover, the MININFRA building was rehabilitated.

Among the constraints met in implementing strategies related to habitat and town planning, are the following:

○ Inadequate legal framework;

- Insufficient funds to provide shelter to an estimated 177,000 homeless households;

- Limited access to housing mortgages because of low incomes;

- Difficulty of expropriation of identified habitat sites;

- Insufficient availability of building materials;

- Lack of (updated) master plans for all cities in the country;

- Absence of housing development and viability of new sites;

- Insufficient resources to reorganize unplanned areas;

- Insufficiency of public buildings and their maintenance 


\subsection{Cross cutting issue - Information Communications Technology}

The role of ICT in poverty reduction is through its catalytic and leveraging effect on improving access to basic services, creating global markets and earning opportunities for wealth and job creation. Three main public institutions are involved in ICT: MININFRA, RITA, and RURA.

\section{Table 12.3 Objectives and performance indicators for the ICT sector}

\begin{tabular}{|c|c|c|}
\hline Objectives & Indicators & Targets \\
\hline $\begin{array}{l}\text { Promote Universal Access } \\
\text { Ubiquitous and affordable access } \\
\text { to ICT }\end{array}$ & $\begin{array}{l}\text { - Fixed line subscribers increased from } 25095 \text { in } 2003 \\
\text { to } 25862 \text { in } 2004 \\
\text { - Mobile phone subscribers increased from } 97261 \text { in } \\
2003 \text { to } 137167 \text { in } 2004 . \\
\text { - } 44 \text { VSATs installed in rural areas (ARTEL) } \\
\text { - Exploitation licenses with performance indicators } \\
\text { elaborated (RURA) } \\
\text { - Privatisation of Rwandatel and granting of } 2^{\text {nd }} \\
\text { national mobile network licence }\end{array}$ & $\begin{array}{l}\text { Citizen to access and use } \\
\text { information to create, } \\
\text { accumulate and disseminate } \\
\text { knowledge. }\end{array}$ \\
\hline $\begin{array}{l}\text { Promote Knowledge Workers } \\
\text { Human capacity development } \\
\text { through integrated education, } \\
\text { training and skill-based } \\
\text { programmes to enable a critical } \\
\text { mass to utilize computers and } \\
\text { online resources. }\end{array}$ & $\begin{array}{l}\text { New programmes to be introduced at KIST and } \\
\text { NUR; } \\
\text { Implementation of National SchoolNet project. In } \\
2003,2 \text { schools per province were given } 2 \\
\text { computers. In 2004, Teachers were trained on basic } \\
\text { computer knowledge. Training will continue during } \\
\text { 2005. } \\
\text { Developed National computer curriculum for primary } \\
\text { and secondary schools. }\end{array}$ & $\begin{array}{l}\text { Produce annually } 100 \\
\text { graduate engineers; } \\
\text { All schools connected to } \\
\text { same network and exchange } \\
\text { information. }\end{array}$ \\
\hline $\begin{array}{l}\text { e-Government } \\
\text { Deployment of e-government } \\
\text { infrastructure and provide a } \\
\text { common Internet Gateway for } \\
\text { all government ministries via } \\
\text { GOV-Net }\end{array}$ & $\begin{array}{l}\text { Implement fibre optic network backbone to connect } \\
\text { all government buildings. } \\
\text { Facilitated information sharing, exchange and } \\
\text { interchange between ministries and public } \\
\text { institutions. }\end{array}$ & $\begin{array}{l}\text { All ministries to have } \\
\text { broadband internet } \\
\text { connection by the end of } \\
2004 \text {. } \\
\text { Commission and complete } \\
\text { the GOV-NeT project } \\
\text { implementation report by } \\
2004 \text {. }\end{array}$ \\
\hline $\begin{array}{l}\text { Raise the level of awareness in } \\
\text { the general public and facilitate } \\
\text { the role of the private sector in } \\
\text { the process towards information } \\
\text { society and economy }\end{array}$ & $\begin{array}{l}\text { People educated on the role that ICT can play in } \\
\text { socio-economic development } \\
\text { Implement special tax instruments and incentive } \\
\text { packages in the } 2004 / 2005 \text { budgets to speed up the } \\
\text { growth of the ICT-related service sector and increase } \\
\text { its export capability. }\end{array}$ & $\begin{array}{lcr}\text { Launch the National ICT } \\
\text { Public Awareness } & \text { and } \\
\text { Literacy Programme } & \text { on } \\
\text { Radio and TV by } 2006 & \end{array}$ \\
\hline $\begin{array}{l}\text { To support the development and } \\
\text { the growth of the ICT industry in } \\
\text { the economy to facilitate the } \\
\text { production, distribution and } \\
\text { provision of ICT products, goods } \\
\text { and Services }\end{array}$ & $\begin{array}{l}\text { Developed Government policy to promote the } \\
\text { development of the local computer industry. }\end{array}$ & $\begin{array}{l}\text { Develop and implement by } \\
2004 \text { a Government policy } \\
\text { directive to encourage } \\
\text { educational institutions, the } \\
\text { civil and public service } \\
\text { organizations to purchase } \\
\text { locally assembled } \\
\text { computers and peripheral } \\
\text { equipment and devices }\end{array}$ \\
\hline
\end{tabular}


MININFRA is mainly responsible for formulation of policy and laws, as well as their follow up and enforcement. Rwanda Information Technology Authority (RITA) seeks to catalyse and articulate the national and sectoral ICT strategies and to coordinate their implementation. RURA is responsible for licensing telecommunication operators and regulatory oversight. Objectives and performance indicators for the ICT sector are summarized in Table 12.3.

Substantial progress has been recorded during the past year, even if imperfect and irregular. Although Rwanda's ICT sub-sector is embryonic and still accounting for relatively small share of the economy's output, there is evidence of rapid growth. As Table 12.4 below shows, central government reports the highest levels of ICT engagement while large businesses are concentrated (83\%) in the lowest two levels. SMEs are the most evenly distributed across the spectrum, reflecting the varied conditions under which they operate. Thus the principal actor remains the central government.

Table 12.4 ICT Usage in Rwanda

\begin{tabular}{|l|l|l|l|l|l|}
\hline Sector & $\begin{array}{l}\text { Non- } \\
\text { ICT }\end{array}$ & $\begin{array}{l}\text { CT } \\
\text { Only }\end{array}$ & $\begin{array}{l}\text { Basic } \\
\text { ICT }\end{array}$ & $\begin{array}{l}\text { Networked } \\
\text { ICT }\end{array}$ & $\begin{array}{l}\text { Intensive } \\
\text { ICT }\end{array}$ \\
\hline $\begin{array}{l}\text { National } \\
\text { Government }\end{array}$ & $0 \%$ & $20 \%$ & $33 \%$ & $47 \%$ & $0 \%$ \\
\hline $\begin{array}{l}\text { Local } \\
\text { Government }\end{array}$ & $58 \%$ & $36 \%$ & $5 \%$ & $1 \%$ & $0 \%$ \\
\hline Large Businesses & $39 \%$ & $44 \%$ & $10 \%$ & $5 \%$ & $2 \%$ \\
\hline SMEs & $16 \%$ & $58 \%$ & $15 \%$ & $10 \%$ & $1 \%$ \\
\hline
\end{tabular}

Source: OnTheFRONTIER, Rwanda National ICT Usage Survey, August, 2003

Government's leading role in ICT development is further evidenced by connecting 27 government buildings in Kigali to the fibre optic network backbone in 2004, which should become operational in 2005. For 2006, the deployment of VoIP technology should contribute to a substantial reduction of the communication costs for the public sector. Works on establishing the Internet broadband backbone are currently continuing along the Gitarama Butare route. In the meantime, an e-Government framework document has been developed.

In a joint effort, MININFRA, RITA, and MIFOTRA have cooperated to establish an ICT unit in all government institutions in a bid to promote ICT.

Much progress has also been made over the past year to promote universal access to ICT services. The national telecommunications carrier Rwandatel was privatised and granted a license to operate a second national mobile telecommunications network. This should foster competition in the already thriving mobile network, which has so far been dominated by a single operator. The number of mobile phone subscribers increased by 40 per cent, from less than 100,000 in 2003 to almost 140,000 at the end of 2004. Moreover, RURA developed exploitation licenses with performance indicators. 
To promote ICT in the private sectors, a process for facilitating domain name registration has begun (re-delegation process through Internet Corporation for Assigned Names and Numbers (ICANN)) and the establishment of an ICT association has been prepared.

A communication service delivery policy has been elaborated for the rural areas. Moreover, ARTEL installed an additional 44 VSATs, finance by the newly established Universal Access Fund. For Cyangugu, Gisenyi, Kibuye, and Ruhengeri, tendering procedures for the reconstruction of rural telecommunications networks have been completed.

Insufficient infrastructure, particularly unreliable supply of energy, still remains the biggest impediment to ICT development. In the area of human resources, a small number of suitably trained technicians and lack of vocational schools form another impediment, while the availability of financing for small IT oriented businesses and for investment in ICT by existing and new firms remains restricted. As a consequence, the cost of telecommunication services remains too high.

\section{Table 12.5 Integration of ICT across sectors}

\begin{tabular}{|c|c|c|c|c|c|}
\hline & Key partners & $\begin{array}{l}\text { Current Progress } \\
\text { in integration }\end{array}$ & $\begin{array}{l}\text { Planned } \\
\text { activities } 2005\end{array}$ & $\begin{array}{l}\text { Planned activities } \\
2006\end{array}$ & $\begin{array}{l}\text { Planned activities } \\
2007\end{array}$ \\
\hline Infrastructure & $\begin{array}{l}\text { ECA, UNDP, SIDA, } \\
\text { MININFRA, All } \\
\text { Ministries, Local } \\
\text { authorities, Rwanda } \\
\text { Revenue Authority, } \\
\text { Telecom operators }\end{array}$ & $\begin{array}{lr}\text { Deploy } & \text { core } \\
\text { government } & \text { ICT } \\
\text { infrastructure to } & \text { to } \\
\text { enhance service } \\
\text { delivery through } \\
\text { fibrer optic } \\
\begin{array}{l}\text { connectivity } \\
\text { government } 27 \\
\text { buildings }\end{array} \\
\end{array}$ & $\begin{array}{l}\text { Completion of } \\
\text { Fibre optic } \\
\text { connectivity } \\
\text { work and } \\
\text { commission } \\
\text { delivery of } \\
\text { services }\end{array}$ & $\begin{array}{l}\text { Deploy VoIP } \\
\text { technology to } \\
\text { reduce cost of } \\
\text { telephone calls }\end{array}$ & $\begin{array}{l}\text { Extend the fibre } \\
\text { optic connectivity } \\
\text { to all } 12 \\
\text { provinces }\end{array}$ \\
\hline Government & $\begin{array}{l}\text { All ministries, } \\
\text { President's office, } \\
\text { Prime minister's } \\
\text { office, senate and } \\
\text { parliament }\end{array}$ & $\begin{array}{l}\text { Project } \\
\text { formulation on the } \\
\text { implementation of } \\
\text { government portal } \\
\text { and central } \\
\text { database system }\end{array}$ & $\begin{array}{l}\text { Mobilize } \\
\text { resources for } \\
\text { implementation } \\
\text { and } \\
\text { identification } \\
\text { of } \\
\text { implementing } \\
\text { partners }\end{array}$ & $\begin{array}{l}\text { To connect all } \\
\text { ministries into } \\
\text { central database } \\
\text { system }\end{array}$ & $\begin{array}{ll}\text { Support } & \text { the } \\
\text { development } & \text { of } \\
\text { applications } & \\
\text { packages } & \text { for } \\
\text { each ministry } & \end{array}$ \\
\hline Education & $\begin{array}{l}\text { All Ministries, KIST, } \\
\text { NUR, KIE, } \\
\text { MINEDUC, Donors, } \\
\text { private sector }\end{array}$ & $\begin{array}{l}\text { Facilitate building } \\
\text { of a critical mass } \\
\text { of knowledge } \\
\text { workers } \\
\text { Strengthen local } \\
\text { ICT } \\
\text { entrepreneurial } \\
\text { skills } \\
\text { Facilitate the } \\
\text { development of } \\
\text { content and }\end{array}$ & $\begin{array}{l}\text { To complete } \\
\text { training of all } \\
\text { ICT technical } \\
\text { staff in all } \\
\text { ministries and } \\
\text { public } \\
\text { institutions } \\
\text { under the } \\
\text { SIDA project }\end{array}$ & $\begin{array}{l}\text { Conduct cross- } \\
\text { cutting ICT skills } \\
\text { upgrading across } \\
\text { all ministries and } \\
\text { public institutions } \\
\text { under the } \\
\text { National } \\
\text { Computing } \\
\text { Centre }\end{array}$ & $\begin{array}{l}\text { Strengthen the } \\
\text { national } \\
\text { computing centre } \\
\text { to deliver } \\
\text { international } \\
\text { professional } \\
\text { courses to keep } \\
\text { updated ITSDs } \\
\text { staff in the } \\
\text { ministries. }\end{array}$ \\
\hline
\end{tabular}




\begin{tabular}{|c|c|c|c|c|c|}
\hline & Key partners & $\begin{array}{l}\text { Current Progress } \\
\text { in integration }\end{array}$ & $\begin{array}{l}\text { Planned } \\
\text { activities } 2005\end{array}$ & $\begin{array}{l}\text { Planned activities } \\
2006\end{array}$ & $\begin{array}{l}\text { Planned activities } \\
2007\end{array}$ \\
\hline & & applications & & & \\
\hline $\begin{array}{l}\text { Commerce and } \\
\text { Trade }\end{array}$ & $\begin{array}{l}\text { MININFRA, } \\
\text { MINIJUST, Multi- } \\
\text { Sector Regulator, } \\
\text { Private Sector } \\
\text { Federation, Financial } \\
\text { Institutions and other } \\
\text { Industry Players. }\end{array}$ & $\begin{array}{l}\text { Develop policy } \\
\text { and legislation }\end{array}$ & $\begin{array}{l}\text { Facilitate the } \\
\text { establishment } \\
\text { of trade } \\
\text { information } \\
\text { and } \\
\text { documentation } \\
\text { centre to } \\
\text { address } \\
\text { exporter's } \\
\text { needs. }\end{array}$ & $\begin{array}{l}\text { Increase the } \\
\text { information on } \\
\text { available market } \\
\text { opportunities }\end{array}$ & \\
\hline E-Business & $\begin{array}{l}\text { RURA, Private } \\
\text { Sector, Financial } \\
\text { Institutions, } \\
\text { MINIJUST, } \\
\text { MININFRA, } \\
\text { MINECOFIN, } \\
\text { Operators, Donors }\end{array}$ & $\begin{array}{l}\text { Formulate and } \\
\text { adopt electronic } \\
\text { transaction policy }\end{array}$ & $\begin{array}{l}\text { Establish e- } \\
\text { procurement } \\
\text { system }\end{array}$ & $\begin{array}{l}\text { Promoting online } \\
\text { procurement and } \\
\text { payment }\end{array}$ & \\
\hline Private Sector & $\begin{array}{lr}\text { RPSF, } & \text { MINICOM, } \\
\text { RIEPA, } & \text { Financial } \\
\text { institutions }\end{array}$ & $\begin{array}{l}\text { Promote ICT in } \\
\text { the private sectors } \\
\text { by facilitating the } \\
\text { domain name } \\
\text { registration and } \\
\text { formulation of } \\
\text { ICT association }\end{array}$ & $\begin{array}{l}\text { RITA has } \\
\text { initiated the re- } \\
\text { delegation } \\
\text { process } \\
\text { through } \\
\text { Internet } \\
\text { Corporation for } \\
\text { Assigned } \\
\text { Names and } \\
\text { Numbers } \\
\text { (ICANN). The } \\
\text { formulation of } \\
\text { a none profit } \\
\text { association is } \\
\text { on the way. }\end{array}$ & $\begin{array}{l}\text { Carry out } \\
\text { awareness } \\
\text { programme } \\
\text { through weekly } \\
\text { special } \\
\text { programme on } \\
\text { the TV and } \\
\text { Radio, produce } \\
\text { comprehensive } \\
\text { brochures, } \\
\text { permanent } \\
\text { banners in each } \\
\text { province on the } \\
\text { benefits of ICTs, }\end{array}$ & $\begin{array}{l}\text { Promoting } \\
\text { penetration of } \\
\text { ICTs in private } \\
\text { sector, } \\
\text { description of } \\
\text { programmes to be } \\
\text { implemented } \\
\text { under second five } \\
\text { year NICI plan; }\end{array}$ \\
\hline Agriculture & $\begin{array}{l}\text { MINAGRI, GIS, } \\
\text { Telecom operators, } \\
\text { donors }\end{array}$ & $\begin{array}{l}\text { Implementing GIS } \\
\text { applications to } \\
\text { monitor crops and } \\
\text { increase trade }\end{array}$ & $\begin{array}{l}\text { Establishing } \\
\text { central data } \\
\text { processing, } \\
\text { linked to global } \\
\text { networks }\end{array}$ & & \\
\hline Tourism & $\begin{array}{l}\text { OTPRN, } \\
\text { Private } \\
\text { Financial } \\
\text { Institutions, } \\
\text { MINIJUST, } \\
\text { MININFRA, } \\
\text { MINECOFIN, } \\
\text { Operators, Donors } \\
\end{array}$ & $\begin{array}{l}\text { Facilitating the } \\
\text { development of } \\
\text { online products }\end{array}$ & $\begin{array}{l}\text { Facilitate the } \\
\text { integration of } \\
\text { electronic } \\
\text { museum into } \\
\text { OTPRN } \\
\text { database. }\end{array}$ & & \\
\hline
\end{tabular}




\section{Good Governance}

The Government of Rwanda considers poor governance a major factor in contributing to poverty, violence and disunity. Good governance structures must exist at all levels of government and society to underpin all other efforts to reduce poverty.

This sector encompasses many issues, and is complex to define. For simplicity, good governance issues have been grouped into the following categories:

- Decentralisation

- Defence, Peace and Security

- Unity and Reconciliation

- Criminal Justice System, Human Rights and Gacaca

- Civil Society

- Democratisation, Transparency and Accountability

\subsection{Decentralisation}

Decentralisation supports good governance through emphasising the need for local autonomy, collective action and bottom-up decision making. The poverty reduction strategy depends on mobilising the whole population to participate, identifying problems and contributing to national decisions.

In 2004, MINALOC have operationalised the second phase of the 'Rwanda five-year decentralisation implementation programme' (DIP). After progress during the first phase (2000-03), putting in place different structures and establishing a set of appropriate procedures and mechanisms, the second phase of the DIP (2004-08) looks to ensure the participation of all the population in decision making processes, planning and to facilitate a better allocation of resources in favour of local government. The DIP emphasises a number of cross-cutting issues: reduction of gender disparity, HIV/AIDS, ICT and recommends their inclusion in District Development Plans.

Community organisations and cooperatives showed increased participation in District Development Plans and use of CDF resources during 2004. More permanent staff were appointed at the Sector level, where clear guidelines for activity reporting are now in place. Health and agricultural services were also further decentralised, with community initiated sector-based health posts in place and operational. Education infrastructure has seen increased participation by local communities, both in terms of choosing the facility location and through cash and in-kind contributions.

Fiscal decentralisation is discussed in the Public Financial Management chapter and remains the main challenge to the decentralisation process. The transfer of resources has not matched the political transfer of responsibilities. Overall CDF disbursement was extremely disappointing in 2004 and local government's own revenue-raising could be significantly 
strengthened. Rural districts do often do not have a sufficient local economic base to generate adequate revenues to run their administrative overheads. This is likely to remain so for some years, creating a dependence on central government grants. The Rwandan Association of Local Government Authorities is making strenuous efforts to remedy the situation through training and the sharing of experiences and best practices.

The policy of decentralisation is interpreted, at the lowest level, as a process of planning by communities. The Ubudehe process uses a traditional concept of community action focusing on bringing the community together to solve problems collectively. The Ubudehe policy is progressing, supporting more and more cells with $\$ 1000$ to take action on a problem of their choosing, through detailed discussion and mapping of poverty in the community. It is also feeding back useful results to the central Ubudehe team. For example, using data drawn from over 40 districts engaged in Ubudehe, preliminary results show that the most significant problems faced by local communities are illness and prevalence of diseases, ignorance, insufficient money to access health services, small land-holding size and infertile land. Poverty, food shortage and access to education were at the bottom of the list of 'most significant problems' cited by communities. Each of the 660 Ubudehe projects in Kigali Ngali has led to a set of priorities being identified by local people. Interestingly, although a wide variety of problems were identified, the overwhelming choice for use of the funds $(92 \%$ of projects) was goat rearing. As further data becomes available from Ubudehe, it is hoped that it will be possible to draw clear policy conclusions for all partners engaged in delivering the PRS.

\subsection{Defence, Peace and Security}

Achieving regional stability and guaranteeing the security of people and their property in the country is a necessary precondition for social and economic development. In particular MINADEF and MININTER contribute to this goal.

A steady improvement in the security situation in recent years has visibly contributed to the growth of commercial activities. In 2004, MINADEF worked to cement international peace agreements with neighbours such as DR Congo, Burundi and Uganda. As result of this action the overall security situation improved greatly, resulting in the return of many refugees and the capture or surrender of Interahamwe/Ex-Far militants. As a result of improvements in this area, Rwanda has been able to allocate defence resources to contribute to international peace keeping efforts in Darfur.

The budget allocation to defence has progressively declined since 2001, and from $3.2 \%$ of GDP in 2003 to $2.7 \%$ in 2004. Execution of the recurrent budget improved, from $89 \%$ in 2003 to $98 \%$ last year.

Although the defence budget is now necessarily focused on improving the professionalism of the army, the role of the Ministry of Defence has expanded to contribute to national production by getting involved in construction activities contributing to economic development. The Ministry of Defence has constructed a coffee washing station in Musua, Kigali Ngali which exported 40 MT of coffee in 2004. Two washing stations are have started production at 
Humure and Nayakizu. MINADEF intends to expand these activities, and also intends to introduce sericulture in Rwanda stagewise from the year 2005. The Ministry is also able to contribute to the construction of schools, creating school buildings at around $75 \%$ of the cost to the Government compared to the private sector.

In 2004, many service personnel underwent skills development training aimed at increasing productivity. The Ministry of Defence is now gearing itself to provide the services that would be required to face a national disaster.

Officers and soldiers are being trained inside and outside the country to acquire new skills in various military institutions. There are currently few women soldiers and officers. MOD has deputed the few women in service to various institutions for higher learning and more women are presently being recruited into the system. A number of soldiers have been deputed to various educational institutes within and outside the country to acquire new skills for better utilization in the administration and improvement in productivity. An e-ICT training has centre has been established to improve ICT skills for soldiers. The ministry also contributes to social protection through support for housing for soldiers, assistance to families of soldiers killed in action and through the establishment of a technical school to rehabilitate to ex-child soldiers who were recruited during the conflicts in the 1990s.

Internal security has seen dramatic progress in 2004. Reported crimes fell by $30 \%$ from 2003 to 2004, as a result of sensitization of communities on security and provision of crime information (there were 16 community sensitization activities in 2004), as well as strengthened capacity of the police with officers trained for community policing. 1000 new police officers were recruited in 2004, with 800 successfully completing training. A further 1000 officers will be recruited in 2005 and again in 2006 to achieve a ratio of 1 police officer per 1000 citizens.

Use of ICT by the police was improved with a computer distributed to each Province police station last year and 5\% of police receiving training on ICT. A joint IT network with the Ministry of Justice is planned in the future, following a feasibility study carried out in 2004.

Road accidents have been reduced by 40\% from 2003-2004 due to increased police in the traffic department, resulting in increased highway vehicle traffic patrols and highway check points.

MININTER have also elaborated a strategy to establish CCTV in the city of Kigali by the year 2006, which will improve overall security. Security was also improved in urban areas via a tough policy on relocating street traders to authorized trading premises.

In gender equality, progress was made in 2004 with the National Police preparing a draft law on fighting abuse and violence towards women, now waiting for approval. 2004 also saw the promotion of a police woman to the highest office as Commissioner of Rwanda National Police - the first woman to hold the post in the history of Rwanda. 


\subsection{Unity and Reconciliation}

Given Rwanda's exceptional situation because of the genocide, unity and reconciliation processes are vital to ensuring good governance. The National Unity and Reconciliation Commission (set up in 1999) works to facilitate reconciliation and integration of refugees and other social identities. The NURC strives to create a climate of dialogue in which people from all backgrounds (victims of genocide, families of the perpetrators, released prisoners and others) can meet and discuss important issues, concerns arising in the country especially those related to the culture of peace, tolerance, democracy and sustainable development, that are crucial for national building. It works to support local institutions wherever possible, since this is most likely to build social cohesion. The National Council of Dialogue, the National Commission for Human Rights, the Gacaca Courts (discussed below), and the National Commission for the Fight Against Genocide also all contribute to unity and reconciliation efforts.

The NURC elaborated a new action plan in July 2004, based around the following five elements:

1. At local community level: The reconstruction of a collective memory through the gacaca jurisdictions and support to individual steps towards reconciliation.

At national level: the promotion of a citizenry considerate and respectful towards one another and the research of historical grassroots of social dissension and the war that destroyed national unity.

2. The reinforcement of measures to integrate the marginalized and the displaced in new local and national institutions of governance.

3. The capacity building of public and private institution and association leaders to judge with fairness and honesty (inyangamugayo) and the capacity building of groups to regulate their conflicts by a process of negotiation so as to increase the citizens' confidence and identification with the local and national community.

4. The capacity building of the community for internal and external "advocacy" and networking in favour of national unity and reconciliation.

5. Rwandan youth civic education based on altruism, justice and peace values, the key to building cooperation and participative behaviours.

Although there is still a long way to go to address the legacy of the 1994 genocide and overcome negative attitudes towards unity and reconciliation, impressive progress was made in 2004:

- More than 720 voluntary community animators around the country were trained to help the NURC promote reconciliation at local level.

- A national summit was held in May, bringing together over 1000 Rwandans to review progress in reconciliation and debate the way forward

- For the first time, a children's summit on Unity and Reconciliation was held, with support from partners (particularly UNICEF)

- 'Ingando' solidarity camps were held for over 3000 pre-university students, religious groups and others were held to sensitize participants to relevant issues.

- Further ingando camps held for released prisoners, returning refugees and ex-combatants 
- Sensitization workshops were held in every province for sector persons in charge of Gacaca, education, security, gender and representatives of genocide survivors' association.

- Financial support given to local associations (with support of the EU), for example to construct houses for genocide survivors.

- A civic education syllabus was prepared, to address issues of promotion of unity and reconciliation.

- NURC published research on democratization and decentralization process and the origins of the Rwandan conflict.

Going forward, all these activities will continue, whilst further research will be carried out on contentious issues such as land-ownership as well to monitoring the success of the Gacaca programme. A peace centre will be opened in 2005, providing a focal point for research activities. The new education syllabus will be distributed for use in schools.

\subsection{Criminal Justice System, Human Rights and Gacaca}

Crucial to both internal security and unity and reconciliation efforts is a functioning criminal justice system.

The judicial system reform process was completed in 2004, with:

- Judicial personnel recruited to fill positions at National and provincial levels (however, they will still require further training to conform to the requirements of the system).

- Old laws reviewed and new ones enacted in accordance with governance needs

- 1545 abunzi committees set up in sectors, to provide community level arbitration for disputes, especially land-related conflicts.

- Elaboration of a sectoral strategy document for the whole sector.

- A new law against drugs, and a new law against sexual violence, particularly towards children.

\subsubsection{Prisons}

Management of an effective prisons service has been hindered by a huge backlog of cases resulting from the 1994 genocide, cases which the Gacaca system is helping to process. The large prison population presents a significant burden on state resources, meaning that financial constraints are the most pressing problem

2004 saw several important reforms in the prisons sub-sector.

- MININTER made progress in shifting prisons from cities to rural areas, creating new modern prisons for decent and adequate space for detention

- A biogas initiative was also established in all prisons to protect the surrounding environment from prison establishment and contribute to the objective of making the prisons more self-sufficient, thereby reducing the financial burden on the state.

- MININTER has facilitated the rehabilitation and reinsertion of detainees into social life and these activities have been achieved through manual labour and training and developing cultural activities within national prisons. 
- MININTER has designed the draft law for the management of National Prison Services that was approved by Cabinet

- The new Kigoma prison in Nyanza was completed and inmates transferred. This facility accommodates 7,500 detainees to internationally accepted standards.

\subsubsection{Human Rights}

Progress was made on integrating human rights issues into the law enforcement services during 2004:

- The prison services have promoted Human Rights by training prison staff against torture, as counsellors, on children rights and the rights of vulnerable groups within prisons.

- MININTER developed a Human Rights Training Handbook for law enforcement agencies

- MININTER has carried out trainings on Human rights for police officers, covering issues of torture, sexual and gender based violence and children's rights. They have provided pocket guidebooks on human rights for all police officers.

\subsubsection{Gacaca}

The Gacaca courts were rolled out across all districts in Rwanda during 2004, involving nearly all the population in this process of local justice, helping to speed-up the processing of cases and promote reconciliation based on truthful confession of genocide related crimes committed during 1994.

To roll-out and reinforce the Gacaca programme and corresponding TIG (Travaux d'intérêt Général) steering committee:

- over 12,000 Gacaca courts were established

- over 200,000 copies of the journal Inkiko Gacaca were distributed to the population

- the organogram and strategic plan (2005-2007) of the TIG steering committee were produced

- meetings, conferences, debates and research (as described above) were held to sensitize the population on the Gacaca process.

- MININTER and MINIJUST are in the process of developing a joint information technology network which will facilitate the easy monitoring of the Gacaca system.

Some serious constraints to the Gacaca process still remain, however. The number of Gacaca courts is still few compared to the number of cases to be processed (so the pressure on prisons is only being relieved slowly); Gacaca judges are relatively inexperienced and have difficulties in handling evidence; most seriously there are reports of harassment of genocide witnesses and survivors, creating obstacles to providing open testimony.

Within the prisons, there has been wide and broad sensitization of the inmates about Gacaca jurisdiction and a good number have responded and confessed their involvement in the 1994 Genocide. 
People of different background have been united through income generating associations. These associations have helped in providing shelter to the vulnerable groups and promoting Gacaca courts:

- Gacaca judges, committees of mediators and other community groups were trained on reconciliatory justice and conflict management to settle disputes.

- Since the ideology of genocide has been a problem in schools, there have been debates among students and teachers in different schools that have resulted into finding ways and solutions to fight this genocide ideology.

\subsection{Civil Society}

Encouraging the growth of civil society will complement the Government's strategies by fostering participatory planning and service delivery (some CSOs may be able to assist with service delivery), decentralization (by empowering local communities to participate in decision making) and democratization (through increased awareness of the population).

During 2004, a database of civil society organizations was set up, and new NGOs being registered. The absence of a policy and law setting out the relationship between government and civil society organizations has been a constraint, but work on drafting these is now underway (2005). This will help ease the relationship between some civil society organizations and government. A 'platform' currently exists for local civil society organizations, which provides a forum for coordination. A more substantial forum, bringing together all civil society organizations to improve harmonization and coordination is still lacking.

In wider civil society, there was further liberalization of the media in 2004, with several new radio stations and some new print media in operation. Provincial radio stations have been established to promote grassroots participation in the dissemination of information, and there has been increased outreach through various radio and TV shows, such as "kubazabiterakumenya" ("when you ask, you know"). In future years, it will be important to further develop the quality of the media, particularly in investigative journalism.

\subsection{Democratisation, Transparency and Accountability}

Ensuring a transparent, democratic society which is free of corruption and accountable to the whole population is a challenging task, but a pre-requisite to successful poverty alleviation programmes. The legitimacy and credibility of government contributes to the success of all its programmes.

Strides were made in further democratization of the country and its processes. By-elections were carried out to fill around 45 vacant positions in local government and an annual national conference was held in 2004 to review achievements in democratization and set out priorities. A civic education policy and programme was put in place, with a manual produced. Elected leaders are becoming better at mobilizing the population to participate in development programmes, such as soil erosion prevention, socio-economic infrastructure etc... Financial 
resources for running elections are still limited and some elected leaders still lack essential capacities to perform their tasks - a problem linked to high turnover.

Significant progress was made during 2004 with the operationalisation of the Office of the Ombudsman, following the establishment of its constitutional mandate in 2003. The law establishing the Office of the Inspector General of Government was published in the Official Gazette. Other institutions and mechanisms to enforce transparency and accountability have also been put in place - the Auditor General's Office, NTB, RRA etc..

However, the capacities of these institutions are still inadequate, in terms of personnel and systems, and there are inadequate rules and codes of conduct in place to enforce certain aspects of transparency and accountability. As mentioned above, it will be important to encourage investigative journalism in the media.

The activities of the Ombudsman from June 2004 to June 2005 centred on:

- Distribution to the appropriate authorities and checking of the contents of the form for declaration of goods and inheritance. 3,267 forms have been distributed to date (June 2005), with 2,837 filled-in and returned to the Office. This activity is ongoing.

- Sensitization of the population at all levels (members of the Councils of Sectors, Districts and towns, leaders of all elected bodies and the general population), all of which must play their part in the prevention of corruption and the fight against the injustice. The authorities were sensitized to the need to reinforce good governance and to focus on weaknesses in their operation, which is sometimes in infringement of the law or guiding policies and may contribute to harmful consequences for the well being of the population.

- Visits to various institutions, in particular Districts, towns and Provinces, and other important institutions (e.g. NTB, CEPEX, O.A.G, etc) to examine:

$\circ$ whether the laws and regulations which govern them support corruption or injustice

- whether they operate transparently, giving reports to the appropriate authorities,

o whether they have internal control mechanisms as well as external, and

○ to see whether they respect the policy of the good governorship.

This activity continues during 2005.

- Examining complaints and requests made by the whole population and working with leaders of decentralized authorities to provide solutions or responses to these requests.

- In the first two years activities primarily focused on the sensitizing of the whole population to their role in the fight against injustice, corruption and related problems. 


\section{Commercial Sector Development}

\subsection{Key objectives}

The 2004 Poverty Reduction Strategy Progress Report set out 3 general objectives in the area of commercial sector development. These were:

○ Promote Private Investment and Entrepreneurship Development, in particular through actions in the areas of investment promotion, trade agreements, property rights, tourism, and ICT

- Reform the financial sector

- Privatise productive enterprises.

\subsection{Key indicators}

The 2004 PRS Annual Progress Report held the overarching indicators of success as:

$\circ$ average GDP growth of $6 \%$ during 2004-2006, and

○ export volume growth of key commodities at $6 \%$ per year.

GDP growth in 2004 has been estimated at 4\%, so by this indication the first target will not be met. Export value rose $10 \%$ in 2004, but this was more than matched by an increase of imports of $28 \%$. More specific results achieved within the objectives, include:

$\circ$ a dramatic increase in investment (registered and approved projects) from $\$ 60 \mathrm{~m}$ in 2003 to $\$ 227 \mathrm{~m}$ in 2004

- membership of COMESA Free Trade Area and start of Economic Partnership Agreement negotiations with the European Union

- draft land reform law currently in Parliament

0 increase in tourist numbers to 27,000 in 2004

○ the completion of the privatization of Commercial Bank of Rwanda and the Banque Continentale Africaine du Rwanda - the banks were handed over to the new investors in September 2004

- improved audit procedures within the commercial banks and an external audit of National Bank of Rwanda were completed

- RWANDATEL, the national telephone operator and RWANDEX, the major coffee exporter are currently undergoing privatisation.

\subsection{Analysis of sector performance}

The aims for development of the commercial sector focus on raising investment, encouraging savings and on developing the private sector to enable industrialisation and facilitate the growth of exports over imports. During 2004 rapid progress was made in a number of these areas

A major contribution to the growth in export value came from higher prices and increased production of coffee. In 2001-3 Rwanda exported between 15,000 and 20,000 tons of coffee 
per year. In 2004, in part due to favourable weather conditions, but also due to the maturation of new coffee trees planted in 1999, coffee production and exports almost doubled to nearly 30,000 tons. Tea production, however, has not experienced growth in output, rising between 2002 and 2003, but falling in 2004 to 11,600 tons due to a strong drought and frosts.

Exports of mining products also increased substantially. To strengthen this sector, a policy for Mines and Geology was approved by the Council of Ministers in 2004 and a sector strategy elaborated. Furthermore, a revised draft on the mining and quarrying code is schedule to be approved by Parliament in 2005.

As described above, progress on investment in 2004 was rapid and this has continued in the first quarter of 2005 with a $62 \%$ increase over the same period in 2004. A large proportion of this new investment has come from domestic investors, particularly focused in the construction sector. International investment has also grown strongly supported by RIEPA's efforts at promoting Rwanda to foreign investors through attending and hosting investment conferences, as well as through setting up a one-stop-shop for investment. Long-term stable macroeconomic policies have also had a very positive impact.

However, despite this rapid growth in investment, success in driving through privatisation reforms has been hampered by difficulties attracting investors into state-owned enterprises, particularly tea factories. During 2004 one tea factory - Pfunda - was privatised. The unacceptably low value of bids for tea factories and general lack of interest in investing in the tea sector has in large part been due to the significant ownership stake agreed with current employees.

The tourism sector continues to grow strongly with $63 \%$ more visitors to national parks in 2004 compared to 2003. Much of this growth is a result of an increase of over 7,000 in the number of Rwandan visits to Akagera National Park $^{9}$, a result of investments in tourist infrastructure, particularly hotels. Receipts are up $45 \%$ whilst foreign tourists visiting national parks have shown an encouraging 35\% increase, with more flights to Rwanda and more passes per day to visit the gorillas. This growth path looks set to continue with more investments underway in 2005 and promotion of Rwanda tourism at the international expo in Aichi, Japan.

\footnotetext{
${ }^{9}$ The Government has made extensive use of the facilities for conferences and workshops, with the construction of the new Akagera Lodge.
} 
Table 14.1 Tourism Indicators

\begin{tabular}{|l|l|l|l|}
\hline & $\mathbf{2 0 0 3}$ & $\mathbf{2 0 0 4}$ & \% change \\
\hline Visitors to national parks & & & \\
\hline Foreign & 10,658 & 14,397 & $35.1 \%$ \\
\hline Rwandan & 5,880 & 12,601 & $114.3 \%$ \\
\hline Total & 16,538 & 26,998 & $63.2 \%$ \\
\hline & & & \\
\hline Air passengers & & & \\
\hline Rwandair & 27,360 & 48,484 & $77.2 \%$ \\
\hline All airlines & 116,638 & 132,504 & $13.6 \%$ \\
\hline & & & \\
\hline Tourist receipts (USD m) & 30.1 & 43.5 & $44.5 \%$ \\
\hline
\end{tabular}

New efforts to increase industrialisation and to facilitate private sector development have also had some impact, particularly through improving business support and through supporting rural micro-enterprises, although there is still much progress to be made. Rwanda Private Sector Federation has elaborated a strategic plan for engaging with, supporting and lobbying on behalf of businesses.

The impact of these achievements during 2004 has been to raise employment, particularly in the construction and tourism sectors and to raise the incomes received from coffee production. A significant proportion of these increased revenues and jobs should be located in the poorer rural areas of Rwanda, however, data on this is will only begin to be collected in the future.

MINICOM's budget execution for 2004 is reproduced in Table 14.7 in the appendix to this chapter. It is hoped that in future APR documents, execution data will be presented for the sector as a whole. Generally execution levels were high, with the exception of 4 tourism based projects that did not take place. Further sizeable unspent budgets reside with PPPMER and are mainly a factor of the late start of the project in July 2004.

\subsection{Sectoral policy development}

Rwanda is in the final stages of the Integrated Framework process which will produce detailed policy recommendations for the way forward. Also over the last year Rwanda has become an increasingly active member of COMESA and has applied for membership of the EAC. These developments, alongside the Economic Partnership Agreement (EPA) negotiations provide the framework for Rwanda's commercial sector development over the next few years.

New objectives have been developed for the commercial sector to overcome the constraints to trade identified by the Integrated Framework process. The background to these new objectives, is the Integrated Framework poverty analysis which highlighted that farmers of commercial crops are significantly less likely to be poor than those subsistence farming. The same is true of people working in the non-farm sector. Therefore encouraging subsistence farmers who make up the majority of the rural poor to switch into commercial crop production or to move out of farming altogether would have a significant impact on poverty. For example: switching into 
coffee production from subsistence farming could raise poor households' income by over $25 \%{ }^{10}$

Strongly connected to these findings is the recognition that the major constraint to Rwanda's export growth is the lack of production of commercial goods and services. Hence moving subsistence farmers into commercial crops or non-farm activities should also increase the supply of goods with commercial value produced for the domestic and external markets.

However, there are many barriers to such movements, including:

○ a lack of knowledge of trade opportunities

- lack of utilisation of good farming practices and standards

○ poor rural transport links, high international transport costs and inefficient customs procedures

- a lack of access to credit and weak organization of the rural sector

$\circ$ weakly developed industrial and service sectors.

It is clear that removing one or two of these barriers on their own would have a limited impact. For example, disseminating information about markets and improving rural roads but not providing easier access to credit, would mean that only relatively wealthy farmers can take advantage of new opportunities. Therefore a holistic approach is needed to enable the transition from subsistence agriculture to a commercially based economy. This transition is essential for the reduction of poverty and growth of trade and is a central tenet of Rwanda's Vision 2020.

\subsection{Revised key objectives and indicators}

Based on this holistic approach to commercial sector development the following new objectives have been identified. They will require integration and co-ordination across a range of sectors, notably infrastructure and agriculture.

\section{Objective 1: Increase production and improve quality of existing export products}

The transition from subsistence farming to commercial activities would be facilitated by measures to increase productivity and value added among commercial crop producers and exporters, e.g. through more care during farming or in greater processing. Such measures will raise the incomes for producers and exporters alike and provide greater incentives for subsistence farmers to make the transition to commercial activities. While commercial sector farmers are not among Rwanda's poorest, raising their incomes would still have a direct impact on poverty, particularly through raising the income paid to labourers e.g. tea pluckers.

\section{Objective 2: Encourage diversification into new agricultural products}

Non-traditional agricultural crops such as horticulture or hides and skins have high potential to reach new export markets for Rwanda and the opportunity for higher incomes for farmers and their families. Diversification also reduces the potential dangers of over-reliance on a narrow range of products that may suffer from bad harvests or an external shock such as a rapid price fall. The production of other crops or processing of agricultural products such as leather may

${ }^{10}$ World Bank, (2005) Draft DTIS Report 
also facilitate the reduction of food and clothing imports, e.g. wheat or shoes, so improving Rwanda's balance of trade.

\section{Objective 3: Provide an environment conducive for investment and private sector development}

If the longer term objective for sustained growth is to be fulfilled then there will have to be a substantial expansion of private sector activities in Rwanda. Providing an environment conducive for investment and private sector development is therefore a critical requirement for long-run growth and employment generation. Legal reform is currently incomplete and there is a need to further strengthen the legal system and the capacity of legal professionals to effectively and consistently apply business laws. Specific regulations relating to land ownership, and improving the services of the cadastre system in order to modernize land titling and improve registration are of particular importance in order to facilitate access to credit. Similarly rules on competition and intellectual property are essential to support the ICT strategy.

\section{Objective 4: Reduce costs of participating in commercial activities}

The poor quality of rural roads substantially increases vehicle operating costs and therefore the price of transport services, at the same time as causing damage to agricultural produce. Improving the rural road network should reduce these local costs and raise the returns to farmers. A lack of access to transport services is also a prohibitive constraint on the ability of rural farmers to participate in commercial activities. Improving rural roads is necessary to open the opportunity to more rural families to produce commercial goods and services and so the potential for higher returns and incomes. Similarly customs procedures add long delays and unnecessary costs to businesses. Streamlining the Magerwa processes is currently underway, but further work is needed to make customs and warehousing procedures more efficient and effective.

\section{Objective 5: Improve the organization of the rural sector and improve financing of the commercial sector}

One of the major constraints to development in rural areas is a lack of knowledge of improved farming methods or potential markets and a lack of access to credit to facilitate movement into cash crop production or to overcome short-term exogenous shocks. Increasing the capacity of cooperatives and associations to provide or demand such services for their members is crucial to achieving the goals of rapid production growth. At the same time increasing the availability of credit to rural areas and reducing the rate of interest paid on such credit is essential to improving the access to finance for the rural poor. Financing needs of businesses more generally also need to be addressed with greater availability of long-term credit and lower rates of interest. This requires further strengthening of the financial sector.

\section{Objective 6: Encourage growth of non-agricultural employment and output}

The general objectives listed above will provide a basis for improvements in Rwanda's agricultural productivity, traditional and non-traditional agricultural export value and should raise the incomes of farmers. However, it is also essential that Rwanda is able to increase its industrial capacity and look towards the service sector, both to reduce the level of imports and increase exports in these non-farm sectors. This will also be important in providing jobs for the 
expanding population and in coping with the potential loss of farm employment if higher productivity is achieved. As with cash crop production, employment in sectors other than agriculture is strongly connected to higher incomes and so reduced likelihood of poverty.

\section{Objective 7: Improve information and support services for businesses}

Current business support services are fragmented, haphazard and underdeveloped. In order to encourage and facilitate entrepreneurship and business growth a more coherent, effective and localised service is needed. This service will need to provide a range of services, in particular information on financing available, as well as training in management skills, market opportunities and good agricultural practices. For example, one agency could be given the responsibility for providing the whole range of services at a district level, with information and technical support from a range of other Ministries and agencies. Furthermore businesses need access to information through enquiry points on SPS, TBT and trade issues.

Key indicators associated with these objectives are summarised in Table 14.2 below.

\section{Table 14.2 Revised Objectives and indicators}

\begin{tabular}{|c|c|c|}
\hline $\begin{array}{l}\text { Key } \\
\text { objective }\end{array}$ & Key indicators & Responsibility \\
\hline \multirow{3}{*}{$\begin{array}{l}\text { 1. Increase } \\
\text { output and } \\
\text { improve } \\
\text { quality of } \\
\text { existing } \\
\text { export } \\
\text { products }\end{array}$} & $\begin{array}{l}\text { Increase productivity of tea and coffee producers: yield per } \\
\text { coffee tree rises from } 0.35 \mathrm{~kg}-0.74 \mathrm{~kg} \text { by } 2010 \text {; yield of tea } \\
\text { plantations increases from } 1,345 \mathrm{~kg} / \mathrm{ha}-2,286 \mathrm{~kg} / \mathrm{ha} \text { (by } 70 \% \\
\text { by } 2010 \text { ). }\end{array}$ & $\begin{array}{l}\text { MINICOM, OCIR } \\
\text { The, OCIR Café }\end{array}$ \\
\hline & $\begin{array}{l}\text { Increase output of fully washed coffee from } 700 \text { tonnes to } \\
24,000 \text { tonnes }(60 \% \text { of total coffee output) by } 2010\end{array}$ & $\begin{array}{l}\text { MINICOM, OCIR } \\
\text { Café }\end{array}$ \\
\hline & Increase proportion of good leaf tea produced to $80 \%$ by 2010 & $\begin{array}{l}\text { MINICOM, OCIR } \\
\text { The }\end{array}$ \\
\hline \multirow{3}{*}{$\begin{array}{l}\text { 2. Diversify } \\
\text { into new } \\
\text { agricultural } \\
\text { products }\end{array}$} & $\begin{array}{l}\text { Produce horticulture strategy and hides \& skins, with support } \\
\text { from OTF Group }\end{array}$ & \multirow[t]{3}{*}{ MINAGRI, RIEPA } \\
\hline & Increase diversity of export products & \\
\hline & Increase fresh produce exported by 50 to & \\
\hline \multirow{7}{*}{$\begin{array}{l}\text { 3. Increase } \\
\text { investment in } \\
\text { productive } \\
\text { sectors and } \\
\text { facilitate } \\
\text { private sector } \\
\text { development }\end{array}$} & Increase level of investment each year & \multirow[t]{6}{*}{ RIEPA, MINICOM, } \\
\hline & $\begin{array}{l}\text { Increase in proportion of registered investments } \\
\text { operationalised each year from } 50 \% \text { in } 2004 \text { to } 75 \% \text { in } 2006\end{array}$ & \\
\hline & One-stop-shop a true one-stop-shop by end 2006 & \\
\hline & $\begin{array}{l}\text { Meet COMESA regulations on competition policy and } \\
\text { Intellectual Property by } 2006\end{array}$ & \\
\hline & $\begin{array}{l}\text { Business survey shows effective business arbitration }+ \\
\text { improved business environment }\end{array}$ & \\
\hline & Reduce time to start a business from 42 to 20 days & \\
\hline & $\begin{array}{l}\text { LARIS system fully implemented and effective, plus funding } \\
\text { to rural areas rising from } 2.3 \% \text { to } 5 \% \text { by } 2006\end{array}$ & MINITERE \\
\hline
\end{tabular}




\begin{tabular}{|c|c|c|}
\hline & $\begin{array}{l}\text { Agree an Economic Partnership Agreement that provides } \\
\text { greater development assistance and more flexibility on rules } \\
\text { of origin }\end{array}$ & MINICOM \\
\hline \multirow{7}{*}{$\begin{array}{l}\text { 4. Reduce } \\
\text { costs of } \\
\text { participating } \\
\text { in } \\
\text { commercial } \\
\text { activities }\end{array}$} & $\begin{array}{l}\text { Ensure national treatment for Rwandan transporters in the } \\
\text { region }\end{array}$ & MINICOM \\
\hline & $\begin{array}{l}\text { Lower transit times on both corridor transport routes by } 50 \% \\
\text { currently average road time is } 12 \text { days }\end{array}$ & MINICOM \\
\hline & $\begin{array}{l}\text { Reduce customs clearance times to } 2 \text { days for imports and } 3 \\
\text { hours for exports by } 2006\end{array}$ & MINICOM, RRA \\
\hline & $\begin{array}{l}\text { Magerwa fee altered to reflect services provided - a choice of } \\
\text { warehousing available }\end{array}$ & MINICOM, RRA \\
\hline & $\begin{array}{l}\text { Increase proportion of main roads in Rwanda that are paved } \\
\text { from } 19 \% \text { to } 30 \%(600 \mathrm{~km} \text { more paved by } 2010)\end{array}$ & MININFRA \\
\hline & $\begin{array}{l}\text { More rational tariff structure, provides lower price of energy } \\
\text { for industry }\end{array}$ & ELECTROGAZ \\
\hline & $\begin{array}{l}\text { Draw up rural roads and rural energy projects for funding by } \\
2006\end{array}$ & MININFRA \\
\hline \multirow{5}{*}{$\begin{array}{l}5 . \text { Improve } \\
\text { the } \\
\text { organization } \\
\text { of the rural } \\
\text { sector and } \\
\text { raise the } \\
\text { proportion of } \\
\text { finance going } \\
\text { to this sector }\end{array}$} & $\begin{array}{l}\text { Increase the number of cooperatives and both output and } \\
\text { productivity of cooperatives }\end{array}$ & MINICOM \\
\hline & Increase total amount of credit disbursed to the private sector & \multirow[t]{4}{*}{ MINECOFIN, BNR } \\
\hline & $\begin{array}{l}\text { Increase proportion of credit to rural areas from } 2.3 \% \text { to } 5 \% \\
\text { by } 2006\end{array}$ & \\
\hline & Increase level of national savings to $4 \%$ of GDP by 2010 & \\
\hline & $\begin{array}{l}\text { Increase proportion of funds going to long-term credit from } \\
20 \% \text { to } 30 \% \text { by } 2007\end{array}$ & \\
\hline \multirow{5}{*}{$\begin{array}{l}\text { 6. Encourage } \\
\text { growth of } \\
\text { non- } \\
\text { agricultural } \\
\text { employment } \\
\text { and output }\end{array}$} & Targets for CIKs and PIKs developed and attained & \multirow[t]{2}{*}{ RITA } \\
\hline & ICT services are cheaper and more readily available & \\
\hline & $\begin{array}{l}\text { Increase proportion of GDP from industry not including } \\
\text { coffee and tea production }\end{array}$ & MINICOM \\
\hline & $\begin{array}{l}\text { Increase value of handicraft exports from } \$ 0.1 \mathrm{~m} \text { in } 2004 \text { to } \\
\$ 0.5 \mathrm{~m} 2006\end{array}$ & MINICOM, RIEPA \\
\hline & $\begin{array}{l}40,000 \text { international visitors per year by } 2007 \text { with average } \\
\text { length of stay } 5 \text { days and average spend per day } \$ 150\end{array}$ & MINICOM, ORTPN \\
\hline \multirow{3}{*}{$\begin{array}{l}\text { 7. Improve } \\
\text { information } \\
\text { and support } \\
\text { services for } \\
\text { businesses }\end{array}$} & $\begin{array}{l}\text { Increased access to and uptake of business support services } \\
\text { (survey) }\end{array}$ & RIEPA, RPSF, RBS \\
\hline & $\begin{array}{l}\text { Three enquiry points on SPS, TBT }+ \text { trade issues are up and } \\
\text { running by end } 2006\end{array}$ & $\begin{array}{l}\text { MINICOM, RBS, } \\
\text { RIEPA, MINAGRI }\end{array}$ \\
\hline & $\begin{array}{l}\text { Monitor and increase number of farmers using good } \\
\text { agricultural practices and meeting standards for export. }\end{array}$ & RBS, MINAGRI \\
\hline
\end{tabular}




\subsection{Monitoring and evaluation}

The list of activities specified in the table above, requires action by a number of different organisations and Ministries. It is hoped that MINAGRI and MININFRA will each take responsibility for undertaking the activities that fall within their remit, while MINICOM will continue to monitor the implementation of such activities. In this way the holistic commercial sector development approach can be retained, while the specific activities outlined are undertaken by different organisations and agencies. In order to ensure that these activities are implemented MINICOM will work closely with its partner Ministries in developing specific project proposals and in sourcing financing for such proposals through the Integrated Framework process. 
Table 14.3 MINICOM Budget and Execution

\begin{tabular}{|c|c|c|c|}
\hline Programme/Sub-Programme & Budget & Executed & Difference \\
\hline Coordination of Ministry programmes & 229573695 & 211646453 & 17927242 \\
\hline$\circ$ Support to the management & 98829421 & 86182833 & 12646588 \\
\hline $\begin{array}{l}\text { Development of policy, strategies and } \\
\text { programmes }\end{array}$ & 130744274 & 125463620 & 5280654 \\
\hline Reinforcement of institutional capacity & 17485549 & 23302003 & -5816454 \\
\hline$\circ$ Support to the management & 12297672 & 18204836 & -5907164 \\
\hline Maintenance of working environment & 4387877 & 4297167 & 90710 \\
\hline Staff training & 800000 & 800000 & 0 \\
\hline Promotion of trade & 100500550 & 92448138 & 8052412 \\
\hline$\circ$ Support to the management & 16178038 & 9228142 & 6949896 \\
\hline $\begin{array}{l}\text { Improvement of the environment for internal } \\
\text { trade }\end{array}$ & 8194474 & 7860588 & 333886 \\
\hline o Consultancy support & 76128038 & 75359408 & 768630 \\
\hline ○ Promotion of exports & 597041110 & 582996375 & 14044735 \\
\hline$\circ$ Support to the management & 12399155 & 7550836 & 4848319 \\
\hline$\circ$ Exports of new products & 15433014 & 15252206 & 180808 \\
\hline $\begin{array}{l}\text { O Dissemination of information on export } \\
\text { markets }\end{array}$ & 116310662 & 116310662 & 0 \\
\hline O Diversify export products by $10 \%$ & 1283200 & 1283200 & 0 \\
\hline ○ Develop an export promotion policy & 450000000 & 440984392 & 9015608 \\
\hline$\circ$ Maintain consistent level of imports & 1615079 & 1615079 & 0 \\
\hline Development of tourism & 729658305 & 82423667 & 647234638 \\
\hline$\circ$ Support to the management & 8099580 & 9447300 & -1347720 \\
\hline ○ Creation of a good working environment & 16752724 & 16778153 & -25429 \\
\hline$\circ$ Marketing of tourism in Rwanda & 7571958 & 7561958 & 10000 \\
\hline ○ Improve working capacities & 2317787 & 2010368 & 307419 \\
\hline$\circ$ Set out quality standards & 11516816 & 11212326 & 304490 \\
\hline $\begin{array}{l}\text { Project - implementation of tourism } \\
\text { development plan }\end{array}$ & 35000000 & 0 & 35000000 \\
\hline $\begin{array}{l}\text { Project - study impact of tourism on national } \\
\text { economy }\end{array}$ & 89826000 & 0 & 89826000 \\
\hline $\begin{array}{l}\text { Project - production of a plan to improve } \\
\text { tourist sites }\end{array}$ & 270893440 & 0 & 270893440 \\
\hline$\circ$ Tourism promotion programme & 287680000 & 35413562 & 252266438 \\
\hline ORTPN & 156411270 & 155890110 & 521160 \\
\hline$\circ$ Support to the management & 122922839 & 122922804 & 35 \\
\hline ○ Caretaking & 4125130 & 4125108 & 22 \\
\hline ○ Strengthening of personnel capacity & 8475351 & 8562158 & -86807 \\
\hline$\circ$ Sensitisation of the population & 2534550 & 2534520 & 30 \\
\hline
\end{tabular}




\begin{tabular}{|c|c|c|c|}
\hline Monitoring & 996500 & 996492 & 8 \\
\hline Publicity & 12118400 & 11982216 & 136184 \\
\hline $\begin{array}{l}\text { Increase value added and diversity of tourism } \\
\text { products }\end{array}$ & 450000 & 454142 & -4142 \\
\hline Renovate roads and new tourist sites & 4788500 & 4312670 & 475830 \\
\hline $\begin{array}{l}\text { Industrial development and promotion of } \\
\text { handicrafts }\end{array}$ & 846808587 & 745315168 & 101493419 \\
\hline o Support to the management & 16127167 & 11102932 & 5024235 \\
\hline $\begin{array}{l}\text { Increasing industrial productivity and } \\
\text { production }\end{array}$ & 47479266 & 27230773 & 20248493 \\
\hline $\begin{array}{l}\text { Project: PPPMER: promotion of rural micro } \\
\text { enterprises }\end{array}$ & 92300000 & 17379669 & 74920331 \\
\hline Rwanda Bureau of Standards & 251735418 & 250695580 & 1039838 \\
\hline Support to the management & 209825168 & 208785330 & 1039838 \\
\hline Development of standards & 13511250 & 13511250 & 0 \\
\hline Quality assurance & 7599000 & 7599000 & 0 \\
\hline Metrology & 20800000 & 20800000 & 0 \\
\hline Rwanda Investment and Export Promotion Agency & 321296736 & 321036214 & 260522 \\
\hline o Support to the management & 273934715 & 273675907 & 258808 \\
\hline Support to investors one-stop-shop & 9115336 & 9115336 & 0 \\
\hline Promotion and marketing & 20143460 & 20141790 & 1670 \\
\hline Information and business research services & 18103225 & 18103181 & 44 \\
\hline $\begin{array}{l}\text { Centre d'Appui Petite et Moyennes Entreprises du } \\
\text { Rwanda (CAPMER) }\end{array}$ & 117870000 & 117870000 & $\mathbf{0}$ \\
\hline$\circ$ Support to the management & 117870000 & 117870000 & 0 \\
\hline Promotion of Cooperatives & 8241600 & 6916600 & 1325000 \\
\hline O Supervision of cooperatives & 2106300 & 2106300 & 0 \\
\hline $\begin{array}{l}\text { O Support for creation of new productive } \\
\text { cooperatives }\end{array}$ & 1360000 & 605000 & 755000 \\
\hline $\begin{array}{l}\text { O Create a favourable environment for } \\
\text { cooperatives }\end{array}$ & 3975300 & 3975300 & 0 \\
\hline Improve working capacity & 800000 & 230000 & 570000 \\
\hline TOTAL & 2685720666 & 1900938514 & 784782152 \\
\hline
\end{tabular}




\section{Social Protection}

\subsection{Introduction}

The area of "social affairs" is a broad field whose limits seem to be difficult to specify.

Taking into consideration the new approach regarding the concept and management of social affairs at a global level, the Rwandan Government, through MINALOC, wants to ensure that all programmes and actions aimed directly at promoting social well being are to follow the "Social Protection" approach.

\section{Its mission and objective}

The policy of social protection is necessary to maintain sustainable economic and social development centred on good social risk management. It falls directly under the general process of poverty reduction and enforces a certain degree of coordination in a range of interventions in social affairs. It reaches beyond assistance type interventions to prevent and mitigate risks that affect vulnerable groups.

\section{The multidisciplinary aspect of the strategy}

As a result of its multidisciplinary nature, the partners in social protection are very numerous and diverse. Indeed, the social ministries, other public institutions under these ministries, bilateral donors, the agencies of the United Nations working in this area, local and international NGOs, insurance companies, micro-finance institutions, savings and credit co-operatives, civil society, trade unions, individuals, households, communities, etc all contribute in one way or another to social protection.

The Ministry most concerned with social protection is MINALOC. It provides safety nets for the poorest and the most vulnerable:

- Support programmes for the survivors of the genocide

- Support programmes for people living with HIV/AIDS,

- Support programmes for refugees and repatriates,

- Support programmes for associations and centres for handicapped people,

- Support programmes for associations and centres for the elderly,

- Assistance programmes for victims of disasters and catastrophes, including floods and food insecurity

- Programmes of Community development (Programmes are HIMO (see 
Other "social" Ministries, such as MINISANTE, MIGEPROF, MIFOTRA, MINICOM, MINECOFIN, MINEDUC, MINAGRI, MINITERE, and MININFRA are direct partners in the area of social protection.

\section{Table 15.1 Key objectives and corresponding indicators}

\begin{tabular}{|c|c|c|}
\hline Objectives & Indicators & Results \\
\hline $\begin{array}{l}\text { To establish a coordination } \\
\text { system of interventions in the } \\
\text { area of social protection }\end{array}$ & $\begin{array}{l}\text { - A policy document on social } \\
\text { protection available and disseminated } \\
\text { - A data base on vulnerability and a } \\
\text { coordination system are established by } \\
\text { MINALOC and shared with partners. } \\
\text { - Percentage of programmes worked } \\
\text { out on the basis of political orientations }\end{array}$ & $\begin{array}{l}\text { - A policy document by the end of } \\
2005 \\
\text { - A coordination system established } \\
\text { and functional by the end of June } \\
2006 \\
-50 \% \text { of elaborated programmes } \\
\text { refer to the National Social } \\
\text { Protection Policy by the end of } 2006\end{array}$ \\
\hline $\begin{array}{l}\text { To promote social welfare and } \\
\text { security for all groups in } \\
\text { society and particularly } \\
\text { vulnerable groups. }\end{array}$ & $\begin{array}{l}\text { - Data on social welfare indicators } \\
\text { (insurance, saving, social security) } \\
\text { existing } \\
\text { - Updated Legal Framework on social } \\
\text { security. } \\
\text { - Mechanisms of social risk } \\
\text { management having direct impact on } \\
\text { the economy. "Prevention is better than } \\
\text { cure". } \\
\text { - Data on informal practices of social } \\
\text { risk management existing }\end{array}$ & $\begin{array}{l}\text {-Social Security for health and work } \\
\text { insurance cover } 30 \% \text { of the } \\
\text { population by the end of } 2006 \\
\text { - An information system is put in } \\
\text { place on the risks to the agricultural } \\
\text { and medical sectors by the end of } \\
2006 \text {. } \\
\text { - A report on the informal practices } \\
\text { of social risk management available } \\
\text { at the end of } 2005\end{array}$ \\
\hline $\begin{array}{l}\text { To promote strategies to } \\
\text { mitigate agricultural risks }\end{array}$ & $\begin{array}{l}\text { - Data on the principal climate related } \\
\text { risks in the agricultural sector } \\
\text { - Storage and transformation system of } \\
\text { agricultural produce } \\
\text { - Percentage of the population } \\
\text { sensitized on welfare and savings }\end{array}$ & $\begin{array}{l}\text { Storage systems are initiated in } 5 \\
\text { Districts most affected by drought } \\
\text { before June } 2006 \text {. } \\
-30 \% \text { of the population are able to } \\
\text { deal with agricultural risks by the end } \\
\text { of } 2006 \text {. }\end{array}$ \\
\hline $\begin{array}{l}\text { To reinforce the culture of } \\
\text { solidarity and reciprocity } \\
\text { within the Rwandan } \\
\text { population }\end{array}$ & $\begin{array}{l}\text { - Percentage of vulnerable } \\
\text { (handicapped people, elderly, orphans) } \\
\text { supported and helped to subscribe to } \\
\text { Community associations mutuelle } \\
\text { health insurance scheme. } \\
\text { - Subscription rates to mutuelle health } \\
\text { insurance schemes by vulnerable } \\
\text { groups }\end{array}$ & $\begin{array}{l}\text { Membership rates to the health } \\
\text { mutuelle insurance scheme goes up } \\
\text { to } 80 \% \text { by the end of } 2006\end{array}$ \\
\hline $\begin{array}{l}\text { To set up mechanisms } \\
\text { allowing the active } \\
\text { participation of vulnerable } \\
\text { groups in actions and } \\
\text { programmes targeted at them. }\end{array}$ & $\begin{array}{l}\text { - Capacity building strategies for the } \\
\text { associations of the vulnerable and } \\
\text { deprived } \\
\text { - Safety nets }\end{array}$ & $\begin{array}{l}\text { - Associations of the elderly and } \\
\text { handicapped people organized and } \\
\text { operational by the end of } 2005 \text {. } \\
\text { - Per province, two associations for } \\
\text { the vulnerable are supported before } \\
\text { June } 2006 \text {. }\end{array}$ \\
\hline
\end{tabular}




\section{Problems}

- Institutional instability: from MINEREISO to MINITRASO to MIGEPROFE to MINAFASO and finally to MINALOC.

- The socio-economic situation inherited by the genocide which continues to weigh on the country: many people living below the poverty line $(60,29 \%)$ and a great number of vulnerable.

- Various risks existing in Rwanda (pluviometric changes, HIV/AIDS and other illnesses, problems related to (un)employment.) and large numbers of vulnerable groups. We have: orphans and other vulnerable children, widows, the youth and young adults, demobilized soldiers, survivors of the genocide.

- Lack of coordination and harmonisation between programmes in the social sector

- Insufficiency and inefficiency of existing programmes aimed at vulnerable groups.

Principal achievements over the last few years:

○ Programmes in favour of the elderly, handicapped people, orphans, street children, people exposed to natural risks (droughts, flood, volcanic eruption,...) pregnant women and other social groups likely to be victims of an unspecified risk.

- Existing actions as regards insurance and social welfare and mutual health insurance scheme.

Principal actions undertaken for the last year:

- Social Protection Policy

- Other achievements in the social sectors were realised with MINALOC as well as with other social Ministries:

- Preparation of a Policy on the mutuelle health insurance scheme and training modules by MINSANTE

- Draft of the Employment Policy by MIFOTRA

- Installation of the National Council for refugees by MINALOC

- Draft of a law benefiting the elderly and handicapped, by MINALOC

- Installation of a National Service of Risk management and Catastrophes by MINALOC

- The installation of national commission to fight against the genocide by the MIJESPOC

- Draft instructions governing the operation of FARG following reforms of the civil service by MINALOC

The introduction of the mutuelle insurance schemes contributes to the social protection of the indigent part of the population, as they are included in the insurance scheme through solidarity mechanisms. Mutuelle activity is owned by local government, with a three layer system of management provided by customers, providers and regulators. Each of these groups has a clear role, and activities complement one another. The mutuelle system has started to address what had been a major constraint on access to healthcare: the costs. As a result, mutuelles are trusted within the communities they serve, and the early indications are that they are benefiting the most vulnerable in the communities, such as child-headed households. There is a plan to introduce subsidies to assist the poorest to join mutuelles in 2005 . 
Table 15.2 Integration of Social Protection across government

\begin{tabular}{|c|c|c|c|c|c|}
\hline Sector & Key partner & $\begin{array}{l}\text { Current Progress in } \\
\text { Integration }\end{array}$ & Planned activities 2005 & Planned activities 2006 & Planned activities 2007 \\
\hline Agriculture & MINAGRI & & $\begin{array}{l}\text { Identification of the areas } \\
\text { exposed to food } \\
\text { insecurity }\end{array}$ & $\begin{array}{l}\text { - Development of systems of } \\
\text { storage } \\
\text { - Identification of the agricultural } \\
\text { risks related to the climate }\end{array}$ & $\begin{array}{l}\text { - Development of systems of storage } \\
\text { - Identification of the agricultural } \\
\text { risks related to the climate }\end{array}$ \\
\hline $\begin{array}{l}\text { Water and } \\
\text { sanitation }\end{array}$ & MINITERE & $\begin{array}{l}\text { access to drinking } \\
\text { water }\end{array}$ & - access to drinking water & - access to drinking water & - access to drinking water \\
\hline Infrastructure & MININFRA & $\begin{array}{l}\text { access to energy } \\
\text { (firewood) }\end{array}$ & $\begin{array}{l}\text { access to energy } \\
\text { (firewood) }\end{array}$ & access to energy (firewood) & access to energy (firewood) \\
\hline Health & MINISANTE & $\begin{array}{l}\text { Sensitizing with } \\
\text { family planning } \\
\text { - Food Assistance in } \\
\text { the centre of health }\end{array}$ & $\begin{array}{l}\text { - Integration of } \\
\text { vulnerable groups in the } \\
\text { mutuelle health insurance } \\
\text { scheme } \\
\text { - Contribute to family } \\
\text { planning and prevention } \\
\text { of HIV/AIDS }\end{array}$ & $\begin{array}{l}\text { - Integration of vulnerable } \\
\text { groups in the mutuelle health } \\
\text { insurance scheme } \\
\text { - Contribute to family planning } \\
\text { and prevention of HIV/AIDS }\end{array}$ & $\begin{array}{l}\text { - Integration of vulnerable groups in } \\
\text { the mutuelle health insurance scheme } \\
\text { - Contribute to family planning and } \\
\text { prevention of HIV/AIDS }\end{array}$ \\
\hline Education & MINEDUC & $\begin{array}{l}\text { - Support with the } \\
\text { schooling of the } \\
\text { vulnerable children } \\
\text { - Schooling of the } \\
\text { handicapped people }\end{array}$ & $\begin{array}{l}\text { Identification } r \text { and } \\
\text { schooling of vulnerable } \\
\text { children }\end{array}$ & $\begin{array}{l}\text { Contribute to schooling of } \\
\text { vulnerable and young people }\end{array}$ & $\begin{array}{l}\text { Contribute to schooling of vulnerable } \\
\text { and young people }\end{array}$ \\
\hline $\begin{array}{l}\text { Human } \\
\text { Resource and } \\
\text { Capacity } \\
\text { building }\end{array}$ & MIFOTRA & $\begin{array}{l}\text { - indemnities of } \\
\text { maternity } \\
\text { - Pension }\end{array}$ & $\begin{array}{l}\text { - To contribute to reforms } \\
\text { existing systems of social } \\
\text { security } \\
\text { - Reinforcement of the } \\
\text { capacities of the co- } \\
\text { operatives }\end{array}$ & $\begin{array}{l}\text { - Extension of the social security } \\
\text { in the informal sector } \\
\text { - Set up strategies of } \\
\text { employment creation and to face } \\
\text { unemployment }\end{array}$ & $\begin{array}{l}\text { - Extension of social security in the } \\
\text { informal sector } \\
\text { - To set up strategies of employment } \\
\text { creation and to face unemployment }\end{array}$ \\
\hline Private Sector & MINICOM & - & $\begin{array}{l}\text { - Identification and } \\
\text { reinforcement of micro } \\
\text { finance associations }\end{array}$ & $\begin{array}{l}\text { - Reinforcement of micro finance } \\
\text { associations } \\
\text { - To contribute to legal reforms } \\
\text { of insurance companies }\end{array}$ & $\begin{array}{l}\text { - Reinforcement of micro finance } \\
\text { associations } \\
\text { - To contribute to legal reforms of } \\
\text { insurance companies }\end{array}$ \\
\hline $\begin{array}{l}\text { Governance } \\
\text { and } \\
\text { Decentralizati } \\
\text { on }\end{array}$ & MINALOC & $\begin{array}{l}\text { - HIMO Community } \\
-\quad \text { development Plan } \\
\text { - Welfare Officers } \\
\text { - Ubudehe } \\
\end{array}$ & $\begin{array}{l}\text { - HIMO Community } \\
-\quad \text { Development Plan } \\
\text { - Welfare Officers } \\
\text { - Ubudehe }\end{array}$ & $\begin{array}{l}\text { - HIMO } \\
\text { - Community development Plan } \\
\text { - Welfare Officers } \\
\text { - Ubudehe }\end{array}$ & $\begin{array}{l}\text { - HIMO } \\
\text { - Community development Plan } \\
\text { - Welfare Officers } \\
\text { - Ubudehe }\end{array}$ \\
\hline Statistics & MINECOFIN & $\begin{array}{l}\text { - Data on } \\
\text { handicapped people } \\
\text { - Contribute to poverty } \\
\text { reduction }\end{array}$ & $\begin{array}{l}\text { - Data on handicapped } \\
\text { people } \\
\text { - Contribute to poverty } \\
\text { reduction }\end{array}$ & $\begin{array}{l}\text { - Data on handicapped people } \\
\text { - Contribute to poverty reduction }\end{array}$ & $\begin{array}{l}\text { - Data on handicapped people } \\
\text { - Contribute to poverty reduction }\end{array}$ \\
\hline
\end{tabular}




\subsection{Conclusion}

As mentioned before, social affairs comprise a wide and diverse range of issues. Under the header of Social Protection it is increasingly perceived as an important priority for development. A consensus is emerging on the fact that to accelerate the process of poverty reduction and to lead to sustainable economic and social development, it is necessary to help individuals, households, and communities to manage certain risks. The multidisciplinary nature of the field of social protection makes it a cross-cutting issue.

Rwanda in general and MINALOC in particular attaches great importance to Social Protection as one of its three sub-sectors (Good Governance, Social Protection, and Community Development). In order to fulfil its mission of promoting this sub-sector, the related policy must be quickly put in place and synergies must be established between the various interventions and partners in the field of social protection. 
The global objective of the PDL-HIMO (Labour Intensive Public Works) programme is to contribute to poverty reduction by investing in development infrastructure while generating employment.

\section{Areas of intervention:}

- Roads infrastructure

- Agriculture and environment protection

- Water

- Social infrastructure (health and schools)

PDL - HIMO in action:

1. Tree planting project in Bugesera

- Objective: to fight draught in Bugesera

- Area: districts of Nyamata, Gashora and Ngenda

- $\quad$ Resources allocated: FRw 624,000,000

- Number of persons employed: 10,000 from November 2004 (for 30 months)

2. Kanyonyomba marshland management

- Objective: generate income through production of rice in Kanyonyomba marshland

- $\quad$ Area: 55 ha

- $\quad$ Resources allocated: FRw 72,000,000

- Number of persons employed: 1,600 daily (for 3.5 months)

3. Rural road rehabilitation Gasarenda-Mushishito-Gakoma (Mudasomwa)

- Objective: increase access to inputs and market infrastructure

- $\quad$ Area: $12.5 \mathrm{~km}$ of road

- Resources allocated: FRw 61,000,000

- Numbers of persons employed: 600 daily (for 3.5 months)

4. Food for work project

- Objective: Make Kaduha and Karaba roads practicable

- Area: $10.4 \mathrm{~km}$ and $16.0 \mathrm{~km}$ respectively

- Resources: food for work

- Number of persons employed: 1,700 daily (for 3 months)

\section{Cross-cutting issues:}

- Gender equality: $50 \%$ to $60 \%$ of people employed in these projects are women.

- Health mutuelles: according to a survey in bugesera, $88 \%$ of people employed by the HIMO project in Bugesera become members of health mutuelles.

- HIVIAIDS: 400 people employed by the Kanyonyomba project have undergone voluntary testing while others from Mudasomwa and Bugesera requested testing facilities to be brought closer and for free.

- Savings: people from Kanyonyomba saved FRw 2,017,400 and those from Mudasomwa saved FRw $1,509,750$ in banks while people from Bugesera used various means of savings. The survey in Bugesera showed that $30 \%$ saved in banks, $50 \%$ purchased livestock ( $90 \%$ of goats), $64 \%$ saved participating in tontines, $8 \%$ built houses and 145 persons in Nyamata bought bicycles.

\section{Constraints:}

- Weak capacity of districts to prepare, monitor and evaluate projects,

- Insufficient HIMO projects due to insufficient resources implying that few people are employed and projects use a rolling strategy (employing different people on different days) with perverse effects on the saving capacities. 


\section{Cross cutting issue - Gender}

The long and medium-term development objectives of the Rwandan Government are respectively detailed in its Vision 2020 and the PRSP. These two documents clearly spell out the aspirations of the Rwandan Government to lead the Rwandan people out of poverty and offer it better living conditions while reinforcing its competence. Among other things, the Rwandan Government is committed to promoting gender equality for equitable and sustainable development.

In the area of gender promotion, which is a cross cutting issue, the contribution of all institutions, public, private, U.N., bilateral or multilateral, nongovernmental, etc institutions working in the country is of utmost importance.

This report is thus the result of these various actors in the field of Gender and Promotion of Women and it is the first time that MIGEPROF has produced such a report.

This report comprises seven priority areas, which are

$\circ$ Fight against gender based violence

- Education

○ Health

- Governance

$\circ$ Infrastructure

- Economy

- Agriculture

\subsection{Principal opportunities regarding Gender}

- political good-will to promote gender, particularly the Constitution

- existence of specific mechanisms regarding gender, for example MIGEPROF, PRO WOMEN, CNF, National Gender Policy

- the main orientations of the Government take the gender dimension into consideration: Constitution of 2003, Vision 2020, PRSP, Decentralization

- Increase in the participation rate of Rwandan women in decision-making bodies at the level of Parliament, the Executive, and the Judiciary

\subsection{Major Challenges and Weaknesses}

In spite of these opportunities, the following challenges/constraints still exist:

- Non-systematic integration of gender in Policies, Programmes, laws and Projects and at the operational level

- Lack of gender expertise at all levels

- The socio-economic and political status of women is still weak

- Performance indicators related to gender are not sufficiently developed 
- In spite of the taking the gender dimension into account in some policies and strategic plans of ministries, the operational plans (action plans) of the various institutions do not consider gender

- Insufficient data disaggregated by sex in all areas

The political context for the implementation of gender policy is favourable but major constraints remain at the level of expertise and financial resources in the planning system.

Recommendations for the elaboration of the annual PRS progress report and revision of the PRS:

- In collaboration with partners, MIGEPROF must work out gender related indicators for each sector as a base for follow-up and evaluation of gender in the PRS APR.

- In the process of elaborating PRS II in 2006, each sector with the support of MIGEPROF must work out an operational plan with key gender indicators and a clear system of monitoring and evaluation.

- For future years, MIGEPROF should strive for a sufficiently important progress report on gender issues to justify the inclusion of a full chapter on this subject

- The next PRS document must reflect the report related to Child Protection. 


\begin{tabular}{|c|c|c|}
\hline OBJECTIVES & INDICATORS & RESULTS \\
\hline \multirow{4}{*}{$\begin{array}{l}\text { To make sure that gender } \\
\text { problems } \\
\text { systematically integrated } \\
\text { in all policies and sectoral } \\
\text { programmes of the } \\
\text { Government at national } \\
\text { and local level }\end{array}$} & $\begin{array}{l}\text { Gender dimension forms an integral part } \\
\text { of plans, policies, and sector } \\
\text { programmes at central level and of } \\
\text { decentralized entities }\end{array}$ & $\begin{array}{l}\text { Mechanisms of coordination and } \\
\text { follow-up for process of } \\
\text { popularization of the policy of the } \\
\text { kind agreed and put in execution }\end{array}$ \\
\hline & $\begin{array}{l}\text { The strategy of gender focal points will } \\
\text { be operational and effective at central } \\
\text { level and at Provinces by January } 2005 \\
\text { and at Districts by January } 2007\end{array}$ & $\begin{array}{l}\text { Gender Focal Points are equipped } \\
\text { with knowledge as regards } \\
\text { integration of gender and are } \\
\text { operational within the Ministries } \\
\text { and other Institutions }\end{array}$ \\
\hline & $\begin{array}{l}\text { Gender dimension will be integrated in } \\
\text { the policies and sector plans of } \\
\text { Ministries and Provinces. }\end{array}$ & $\begin{array}{l}\text { Gender promotion strategy } \\
\text { developed and transmitted to all } \\
\text { actors }\end{array}$ \\
\hline & $\begin{array}{l}\text { Gender specific data base of } \\
\text { MIGEPROFE will function properly by } \\
\text { January } 2005\end{array}$ & $\begin{array}{l}\text { Database for an effective system of } \\
\text { follow-up and evaluation using the } \\
\text { gender specific data available }\end{array}$ \\
\hline \multirow{6}{*}{$\begin{array}{l}\text { To promote a legal } \\
\text { framework guaranteeing } \\
\text { gender equality and equity } \\
\text { in all aspects of life; }\end{array}$} & $\begin{array}{l}\text { New legislation in place which is } \\
\text { favourable to women }\end{array}$ & $\begin{array}{l}\text { Legislation revised and new laws } \\
\text { for the promotion of the women } \\
\text { proposed }\end{array}$ \\
\hline & Public awareness campaign on new laws & $\begin{array}{l}\text { Good comprehension of the laws } \\
\text { favourable to women }\end{array}$ \\
\hline & $\begin{array}{l}\text { Proposals for new programmes for } \\
\text { women. }\end{array}$ & $\begin{array}{l}\text { new programmes for the promotion } \\
\text { of women operational }\end{array}$ \\
\hline & $\begin{array}{l}\text { Number of women and/or associations } \\
\text { supported }\end{array}$ & $\begin{array}{l}\text { Women councils and their } \\
\text { associations have suitable work } \\
\text { facilities and an increase in their } \\
\text { economic capacities }\end{array}$ \\
\hline & $\begin{array}{l}\text { A plan for the development of women's } \\
\text { enterprises is available. }\end{array}$ & $\begin{array}{l}\text { Promotion of a culture of } \\
\text { entrepreneurialism and co- } \\
\text { operation as well as knowledge } \\
\text { necessary to meet the needs of } \\
\text { women }\end{array}$ \\
\hline & $\begin{array}{l}\text { Capacity building plan of those who are } \\
\text { elected }\end{array}$ & $\begin{array}{l}\text { Women elected within decision } \\
\text { making bodies profit regularly } \\
\text { from capacity building initiatives }\end{array}$ \\
\hline \multirow{3}{*}{$\begin{array}{l}\text { To establish clear } \\
\text { coordination mechanisms } \\
\text { for all principal actors in } \\
\text { promotion of gender and } \\
\text { equality/equity and } \\
\text { strengthening of women's } \\
\text { capacities; }\end{array}$} & $\begin{array}{l}\text { Annual progress reports in the field of } \\
\text { gender promotion and capacity } \\
\text { strengthening of women }\end{array}$ & $\begin{array}{l}\text { Activities in this field are well } \\
\text { coordinated among all concerned } \\
\text { parties }\end{array}$ \\
\hline & $\begin{array}{l}\text { Regular meetings of gender working } \\
\text { group }\end{array}$ & $\begin{array}{l}\text { Coordination of the thematic } \\
\text { gender working group is } \\
\text { operational }\end{array}$ \\
\hline & $\begin{array}{l}\text { Regular reports on the implementation of } \\
\text { the Beijing action plan. }\end{array}$ & $\begin{array}{l}\text { Follow-up and good coordination } \\
\text { of the reports on the PFAB }\end{array}$ \\
\hline
\end{tabular}




\section{Monitoring and Evaluation}

\subsection{M\&E in the APR process}

Following last year's Annual Progress Report, considerable progress has been made on outlining a more comprehensive framework for monitoring and evaluating performance in all sectors. The use of monitoring and evaluation within the APR drafting process has also been improved; sectoral chapters were required to present statements of progress in terms of key objectives and corresponding performance indicators. Reporting in this way will provide a clear basis on which to assess performance in all priority sectors. The work presented in this year's report is a useful indication of current capacity of line ministries in this area and has stimulated a proposed new M\&E framework.

The principal objective of this new M\&E framework is to strengthen routine reporting in all sectors, working towards the use of best practice in annual reports in joint sector reviews as well as in this report. The education chapter is currently the closest to best practice in M\&E, with a useful set of key performance indicators as well as indicators at the input and output levels. Data are presented for 2003 in most cases, allowing for a comparison of 2004 with previous efforts, whilst targets are given for future years. Some improvements could still be made, for example, by clearly relating the performance indicators to high level objectives.

Other sectors have varying capacity to present a list of key objectives and corresponding performance indicators. Results against indicators should have been used as the basis for analyzing progress. However, with generally weak indicators and targets and an absence of baselines it is sometimes difficult to make an informed assessment of progress during 2004. The methodology is therefore an improvement on previous years, providing a framework for an objective assessment of performance (rather than simply a report on activities carried out). However, weak capacity to set clear objectives and report against appropriate indicators means that strengthening of ministries' M\&E systems is vital for the production of higher quality sectoral reports. Nearly all sectors will need some technical assistance, but the agriculture and rural development, infrastructure, water and sanitation, and governance sectors will need particular support to develop useful indicators for monitoring performance. Good progress towards establishing a new monitoring framework for the commercial sector has been made, with key objectives and performance indicators which provide a basis for comprehensive reporting in future years.

Each lead ministry was also asked to hold a Joint Sector Review with a wide range of partners, to include all implementing agencies, donors and civil society. These Reviews aimed to validate their self-assessment of performance during 2004. Whilst the process worked well in areas such as Education and the Commercial Sector, other lead ministries failed to co-ordinate joint reviews, notably in Good Governance (MINALOC) and Health (MINISANTE). As an analysis of the whole PRSP I period is carried out next year, the Joint Sector Reviews process will require strengthening, with better use of the existing cluster system essential. 
The rest of this chapter sets out progress made in particular M\&E activities during 2004, followed by a description of the changes underway in the institutional framework for M\&E. A third section sets out the proposed new monitoring and evaluation framework for discussion with partners.

\subsection{Progress in M\&E during 2004}

A number of important surveys and studies were undertaken in 2004, set out in Table 17.1, along with planned activities in 2005 and 2006.

Table 17.1 Surveys and Studies realized in 2004 and Revised Plan for 2005-2006

\begin{tabular}{|l|c|c|c|}
\hline Survey/Study & $\mathbf{2 0 0 4}$ & $\mathbf{2 0 0 5}$ & $\mathbf{2 0 0 6}$ \\
\hline Demographic and Health Survey & & $\mathrm{X}$ & \\
\hline $\begin{array}{l}\text { Household Living Conditions Survey } \\
\text { (EICV II) }\end{array}$ & & $\mathrm{X}$ & $\mathrm{X}$ \\
\hline Basic Agricultural Survey & & & $\mathrm{X}$ \\
\hline PRS Trust Fund, including: & $\mathrm{X}$ & & \\
\hline Decentralised M\&E system & & $\mathrm{X}$ & \\
\hline Informal Sector Survey & & & \\
\hline Poverty Mapping Exercise & $\mathrm{X}$ & & \\
\hline PHRD Grant, including: & $\mathrm{X}$ & $\mathrm{X}$ & $\mathrm{X}$ \\
\hline $\begin{array}{l}\text { PETS in Education, Health, Water, } \\
\text { Agriculture }\end{array}$ & $\mathrm{X}$ & & \\
\hline Citizen Report Cards & \begin{tabular}{l} 
\\
\hline $\begin{array}{l}\text { Frontline providers performance } \\
\text { assessment }\end{array}$
\end{tabular} & $\mathrm{X}$ & \\
\hline $\begin{array}{l}\text { Inventory of Water and Sanitation } \\
\text { infrastructure at rural level }\end{array}$ & & & \\
\hline
\end{tabular}

The Public Expenditure Tracking Survey (PETS) in health, education, water and sanitation and agriculture was completed at the end of 2004, highlighting important ways to strengthen public expenditure in these four sectors. Some key results are highlighted in the relevant chapters.

The performance assessment of frontline service providers tried to assess whether Rwandan schools are achieving the government's goal of quality education. For this study, a questionnaire was given to teachers in nine Provinces to assess factors that may be important in the quality of education. The most persistent factors contributing to poor performance in schools were poor involvement of parents, poverty, lack of discipline, and lack of teaching materials.

A pilot study of the Citizen Report Card was carried out in Ruhengeri and Kibungo provinces, whilst questionnaires were drafted on health and education issues for inclusion in trials in 2005. Report cards are used to create awareness among citizens and feedback to government on service delivery. The pilot study asked citizens' perceptions on services relating to identity 
cards, birth registration, marriage registration and death registration. A large majority of respondents expressed satisfaction with these services. However certain problems were highlighted: low awareness of the services, average distance to reach services, lack of adequate and trained staff and lack of necessary materials and equipment were all cited.

Decentralised M\&E pilots were carried out, improving the base of data to be collected in some provinces although they failed to generate a technical proposal on how M\&E should be taken forward at decentralized levels. However, more recently, with support from MINECOFIN, Gitarama province has initiated a trial to collect data on poverty across the district. Furthermore, MINALOC has produced work, in co-ordination with SNV and VNG setting out a possible monitoring and evaluation framework for decentralized service delivery. These two new areas of work will be taken forward under the new comprehensive M\&E system.

The ubudehe process is starting to generate an important source of information for M\&E of poverty at community level. Initial results are discussed in the Good Governance chapter.

\subsection{Institutional arrangements}

In 2004 the Poverty Observatoire completed a comprehensive survey of the state of research on monitoring and evaluation and produced a draft Framework for Monitoring and Evaluation in Rwanda, setting out broad principles. A summary of the key principles for M\&E drawn out of the research is shown in Box 17.1.

Following internal restructuring in MINECOFIN under the civil service reforms, the Poverty Observatoire has changed slightly, and is now called the 'PRS Monitoring and Evaluation' team, located within the Strategic Planning Unit. The main shift in focus is from simply coordinating poverty monitoring to being responsible for a more holistic process of monitoring and evaluation. This process ensures that programmes and strategies are monitored from conception, to budget allocation, to execution and finally in terms of poverty results. The team then works to ensure that lessons learnt feed back into policies.

The team will be supported in their work by the Budget Unit, which contributes by monitoring budget execution, as well as the now-operational Rwandan National Institute of Statistics (RNIS). RNIS will take overall responsibility for collection of macro-economic data as well as for carrying out large scale studies of household living conditions.

M\&E of PRSP programmes continues to suffer from its low starting base at the time of the PRSP (2002), and the process of articulating Sector Strategic Plans is just completing its first cycle. There are corresponding weaknesses in setting clear objectives, indicators and targets; for most sectors, these were not formalized in the original PRSP document.

With the exception of the health and education sectors, routine data systems are fairly weak, which has led to an over-reliance on small-scale surveys. These are not always adequately 'owned' by the institutions responsible for implementing the PRSP ${ }^{11}$.

${ }^{11}$ Surveys are a useful tool in M\&E, but should complement routine data systems rather than compensate for the lack of them. 


\section{Box 17.1 Key Principles for Monitoring and Evaluation}

1. Monitoring implementation of the PRS is the responsibility of the Government of Rwanda.

2. Information should be collected on all PRS priority sectors.

3. PRSP priority sectors should take responsibility for setting their own indicators, targets and data collection requirements and these should be aligned with the objectives and indicators set out in their Strategic Plans.

4. Indicators should focus on measuring the implementation of PRS strategies at least as much as the impact of these strategies (the traditional focus of M\&E activities). For this reason, budget monitoring and administrative data systems (particularly those relating to service provision) are important so that information is collected to complement 'results based' poverty information.

5. The quality of key indicators should be openly assessed by all partners in each PRSP priority area. The quality of data should be periodically cross-checked with other sources (e.g. surveys).

6. The data collection burden on partners should be minimised, therefore the M\&E system should seek to generate the minimum information required to meet the above objectives. The information also has to be easily generated and the M\&E system should use information which is already generated wherever possible (e.g. through ministries' routine data systems). The M\&E system should quickly harmonize government reporting requirements and ultimately lead to a harmonization of donor reporting formats.

7. Building up capacity of routine data systems should be the long term priority, rather than permanent reliance on surveys and studies. Current administrative systems should be strengthened where possible, rather than setting up new ones. As reliance on routine data systems increases, these should be audited periodically.

8. The data collected should easily useable for policy making purposes. This suggests the need for a relatively simple M\&E system. If the data collected is not instantly useable for policy making purposes, it should be manipulated at the central level (where most capacity exists) and then disseminated to users.

9. The policy implications need to be openly debated with a range of partners on a regular basis.

10. Civil society organisations are well placed to assist with independent analysis of data generated by the M\&E system, so as better to contribute to the debate on policy implications. They can also contribute, alongside other partners, by assessing the quality of key indicators. Their role should not be primarily one of generating information as this may compromise their autonomy from Government.

11. The system should allow for comparisons between districts and between ministries. This is because indicators showing relative performance of different agencies are more likely to be taken seriously for the purposes of policy making.

12. The $M \& E$ system should support decentralisation through providing disaggregated information at the Province and District levels. Routine data systems should be adapted where necessary to deliver this disaggregated information.

13. High level political commitment is needed to ensure the responsibilities of collecting information are taken seriously and that the findings are acted upon. A role for parliament in PRS monitoring framework may be desirable.

14. A strong technical team is needed at the centre of the $M \& E$ framework to:

a. identify ongoing data needs for PRS monitoring

b. allocate necessary funding and ensure capacity constraints are being addressed

c. ensure that the information collected is reliable and is made available for PRS monitoring purposes on a timely basis and in a useable format.

d. ensure that the information generated is used to explore policy issues and options 


\subsection{Looking forward}

The envisaged framework to strengthen M\&E in the coming year is set out below.

The overall objective is to set up an M\&E system in which:

- There is a clear evidence base for policy making, so all partners can agree where progress has been achieved and where there are still constraints.

- Agencies responsible for budgets can be held accountable for their use of the funds, to ensure that national priorities (PRSP goals) are met.

- There are some basic incentives for those involved in delivering the PRS to meet targets by making information on their performance publicly available.

To achieve its objective, a simple framework is needed, which builds on ministries' and districts' existing information systems, and collects only the information which is absolutely required. The system should ensure that a certain minimum amount of information is fed back to central levels (where national priorities are set and the budget allocated); but beyond this minimum ministries and districts are free to collect and evaluate further data as they see necessary (the existing systems used in Health and Education may provide a useful benchmark).

Eight stages or actions are needed to make the new framework operational:

i. All line ministries/central spending agencies identify key objectives and corresponding key performance indicators (KPIs) are agreed

ii. Decentralized data sources and responsibilities for collection are defined and capacity is built at decentralized levels to collect data

iii. Baseline figures and interim targets are agreed

iv. As PRSP II is prepared, the relative importance (and comprehensiveness) of objectives will be further discussed, and specific targets set

v. Along with data collection against KPIs, data on budget allocations and execution will also be collected

vi. Progress against targets will be discussed in Joint Sector Reviews and analyzed in subsequent APRs along with appropriate policy recommendations

vii. A national poverty assessment is needed every few years

viii. A system to monitor the performance of Districts and Provinces will need to be established in the medium term 
It is envisaged that steps i-iii would be rolled-out during the second half of 2005 and the rest of the system made operational in 2006, in time for PRSP II.

Key objectives and KPIs needs to be openly discussed and agreed upon by all development partners for progress against these to be meaningfully reported on in subsequent APRs. Where good strategic plans exist, the KPIs should be drawn from them. However, in most cases it is likely that the identification of KPIs should help to sharpen the focus of the strategic plans. Reaching this level of agreement between such a diverse group of stakeholders will not be easy, but could have far reaching benefits in terms of harmonizing interventions in all sectors.

Rwanda's first PRSP, like the PRSPs in many other countries, was somewhat weak in having clear objectives and indicators. It is important that key indicators and baseline data are established in all key PRSP sectors so that the process of elaborating PRSP II during 2006 and 2007 can be centred around an informed debate on feasible targets in all sectors. Once the PRSP is in place, these indicators will make it easier to measure whether progress is on track, and if not, have the information to evaluate why. 


\section{ANNEX}

\section{Table 18.1 Real GDP}

\begin{tabular}{|c|c|c|c|c|c|c|}
\hline GDP Rwf billion & 2001 & 2002 & & $\overline{003}$ & & 04 \\
\hline & 2001 & & est & growth & proj & growth \\
\hline Agriculture & 260.06 & 299.09 & 286.93 & $-4.1 \%$ & 287.05 & $0.0 \%$ \\
\hline Of which: Food crop & 218.19 & 255.90 & 244.39 & $-4.5 \%$ & 241.79 & $-1.1 \%$ \\
\hline Export Crop & 7.82 & 8.15 & 6.49 & $-20.4 \%$ & 8.96 & $38.1 \%$ \\
\hline Livestock & 23.94 & 24.66 & 25.40 & $3.0 \%$ & 25.70 & $1.2 \%$ \\
\hline Fisheries & 1.96 & 1.98 & 2.00 & $1.0 \%$ & 2.00 & $0.0 \%$ \\
\hline Forestry & 8.15 & 8.40 & 8.65 & $3.1 \%$ & 8.60 & $-0.6 \%$ \\
\hline Industry & 106.24 & 112.53 & 120.47 & $7.1 \%$ & 128.80 & $6.9 \%$ \\
\hline Mining and quarrying & 1.41 & 1.33 & 1.21 & $-8.6 \%$ & 1.88 & $54.6 \%$ \\
\hline Manufacturing & 50.18 & 53.11 & 52.09 & $-1.9 \%$ & 55.32 & $6.2 \%$ \\
\hline Of which: Food, beverages, \& tobacco & 41.08 & 43.30 & 41.01 & $-5.3 \%$ & 43.29 & $5.6 \%$ \\
\hline Textiles and clothing & 0.83 & 0.75 & 0.69 & $-8.4 \%$ & 0.63 & $-9.4 \%$ \\
\hline Wood product \& funiture & 1.40 & 1.48 & 1.55 & $5.3 \%$ & 1.81 & $16.3 \%$ \\
\hline Paper and printing & 0.60 & 0.61 & 0.65 & $7.1 \%$ & 0.69 & $6.4 \%$ \\
\hline Chemicals & 1.31 & 1.60 & 2.34 & $45.8 \%$ & 2.53 & $8.1 \%$ \\
\hline Non metals & 3.66 & 4.02 & 4.40 & $9.5 \%$ & 4.53 & $3.1 \%$ \\
\hline Metals & 1.15 & 1.20 & 1.28 & $7.0 \%$ & 1.65 & $28.2 \%$ \\
\hline Others & 0.14 & 0.15 & 0.16 & $7.0 \%$ & 0.20 & $25.8 \%$ \\
\hline Electricity, gas, \& water & 1.62 & 1.75 & 2.03 & $15.9 \%$ & 1.59 & $-22.0 \%$ \\
\hline Construction & 53.04 & 56.34 & 65.13 & $15.6 \%$ & 70.02 & $7.5 \%$ \\
\hline Services & 215.00 & 224.06 & 234.67 & $4.7 \%$ & 253.24 & $7.9 \%$ \\
\hline Wholesale \& retail trade, rest. \& hotels & 47.60 & 48.15 & 48.30 & $0.3 \%$ & 48.77 & $1.0 \%$ \\
\hline Of which: Wholesale \& retail trade & 44.31 & 44.81 & 44.89 & $0.2 \%$ & 44.80 & $-0.2 \%$ \\
\hline Restaurants \& hotels & 3.29 & 3.35 & 3.41 & $1.8 \%$ & 3.97 & $16.5 \%$ \\
\hline Transport, storage, communication & 42.45 & 45.34 & 46.39 & $2.3 \%$ & 52.00 & $12.1 \%$ \\
\hline Finance, insurance, real estate, business & 15.18 & 15.68 & 17.31 & $10.4 \%$ & 20.90 & $20.8 \%$ \\
\hline Public administration & 44.55 & 45.17 & 48.03 & $6.3 \%$ & 52.16 & $8.6 \%$ \\
\hline Non-profit organizations & 5.11 & 5.36 & 5.63 & $5.0 \%$ & 6.19 & $10.0 \%$ \\
\hline Others & 60.11 & 64.35 & 14.49 & $-77.5 \%$ & 16.25 & $12.1 \%$ \\
\hline Less: Imputed bank service charge & 10.87 & 11.25 & 12.49 & $11.0 \%$ & 15.08 & $20.8 \%$ \\
\hline Plus: Import duties & 9.72 & 11.17 & 11.79 & $5.5 \%$ & 12.02 & $2.0 \%$ \\
\hline GDP & 580.16 & 635.60 & 641.36 & $0.9 \%$ & 666.04 & $3.8 \%$ \\
\hline
\end{tabular}

Source: MINECOFIN

Note: 2004 data are estimates while we await the formal end year GDP figures published by the Statistics Department 
Table 18.2 Existing Objectives, Indicators and Targets of CNLS (to be revised under new strategic plan)

\begin{tabular}{|c|c|c|}
\hline Objectives & Core Indicators & Targets (Check these correspond to indicators) \\
\hline $\begin{array}{l}\text { 1.Stabilize the HIV/AIDS } \\
\text { prevalence rate at } 13 \% \\
\text { between } 2002 \text { and } 2006\end{array}$ & $\begin{array}{l}\text { 1.Percentage of vulnerable groups that } \\
\text { adopted low risk behaviour } \\
\text { 2.Number of people from the priority } \\
\text { group screened and treated for STIs } \\
\text { and tuberculosis } \\
\text { 3.Number of voluntary, confidential and } \\
\text { anonymous counselling/screening } \\
\text { structures by province } \\
\text { 4.Number of health structures and high- } \\
\text { risk professional environments that } \\
\text { adopted hygiene measures } \\
\text { 5.-Percentage of the sexually active } \\
\text { population using condoms regularly } \\
\text { 6.-Percentage of protected blood banks } \\
\text { 7.Percentage of pregnant women } \\
\text { screened in the PMTCT centres } \\
\text { 8.Percentage of mobile or migrant } \\
\text { groups that benefited from HIV/AIDs } \\
\text { prevention activities }\end{array}$ & $\begin{array}{l}\text { 2.Ensure early screening and treatment of STI and tuberculosis } \\
\text { among priority groups between } 2002 \text { and } 2006 \text {. } \\
\text { 3.Put in place screening structures - voluntary, confidential and } \\
\text { anonymous counselling in all the provinces of the country between } \\
2002 \text { and } 2006 . \\
\text { 4.Ensure hygiene in health structures and high risk professional } \\
\text { environments exposed to accidental contamination between } 2002 \\
\text { and } 2006 \\
\text { 5.Persuade } 40 \% \text { of the sexually active population ( } 15 \text { to } 49 \text { years) } \\
\text { to use condoms regularly } \\
6 .- \text { Ensure } 100 \% \text { blood transfusion safety of blood banks between } \\
2002 \text { and } 2006 \text {. } \\
\text { 7- Ensure PTMC of all pregnant women screened in PTMC } \\
\text { programme centres between } 2002 \text { and } 2006 \text {. } \\
8 . \text { Ensure prevention of HIV transmission for } 50 \% \text { of mobile or } \\
\text { migrant groups (heavy truck drivers, traders, prostitutes, refugees } \\
\text { between } 2002 \text { and } 2006 \text {. }\end{array}$ \\
\hline $\begin{array}{l}\text { 2.Monitor the trend of } \\
\text { HIV/AIDS and related } \\
\text { diseases, such as STIs } \\
\text { and TB during the } \\
\text { period covered by MNP }\end{array}$ & $\begin{array}{l}\text { 1.Collection of data on HIV/AIDS cases } \\
\text { 2.Quality control of HIV testing } \\
\text { 3.System for annual surveillance of HIV, } \\
\text { plan for data analysis and dissemination }\end{array}$ & $\begin{array}{l}\text { 1.Carry out data collection and notification of STI, tuberculosis and } \\
\text { HIV/AIDS cases in at least } 60 \% \text { of patient care structures between } \\
2002 \text { and } 2006 \text {. } \\
\text { 2.Carry out monitoring of HIV and STI and tuberculosis bacteria } \\
\text { among at least } 6 \text { high risk groups (women, youth of } 15 \text { to } 25 \text { years, } \\
\text { prostitutes, unaccompanied children, truck drivers, soldiers, etc) } \\
\text { between } 2002 \text { and } 2006 \text {. } \\
\text { 3. Carry out epidemiological studies on the population between } \\
\text { 2002 and } 2006 \text {. } \\
\text {-Carry out socio-behavioural and impact studies. }\end{array}$ \\
\hline $\begin{array}{l}\text { 3. Reduce the impact of } \\
\text { HIV/AIDS, STIs and TB } \\
\text { on individuals, families } \\
\text { and communities during } \\
\text { the period covered by } \\
\text { the MNP }\end{array}$ & $\begin{array}{l}\text { 1-Large companies with workplace } \\
\text { HIV/AIDS policies and programmes } \\
\text { 2.Active involvement of PLWA } \\
\text { 3.-National care and support care index } \\
\text { 4.ARV for people with advanced HIV } \\
\text { infection } \\
\text { 5. Health facilities providing ARV drugs } \\
\text { 6. Health facilities with ARV drugs in } \\
\text { stock }\end{array}$ & $\begin{array}{l}\text { 1.-Make all the new and old STI/HIV counselling, screening and } \\
\text { monitoring structures functional in health structures and at } \\
\text { community level. } \\
\text { 2. Give psycho-economic and legal support to } 60 \% \text { of concerned } \\
\text { target groups between } 2002 \text { and } 2006 \\
\text { 3.-Involve at least one PLWA in the structures of public, private and } \\
\text { community intervention sectors involved in HIV/AIDS control. }\end{array}$ \\
\hline $\begin{array}{l}\text { 4.Integrate } \\
\text { poverty/gender/HIV } \\
\text { dimensions in the } \\
\text { policies and sectoral } \\
\text { plans against HIV/AIDS } \\
\text { in the country during the } \\
\text { implementation of MNP }\end{array}$ & $\begin{array}{l}\text { 1.Ration of orphans to non-orphans } \\
\text { who are in school } \\
\text { 2.-Life skills-based HIV/AIDS education } \\
\text { 3.-Community-based programmes that } \\
\text { provide social services to PLWA and } \\
\text { their families that promote access to } \\
\text { socioeconomic opportunities for women }\end{array}$ & $\begin{array}{l}\text { 1.-Give support to income generating activities of } 60 \% \text { of women } \\
\text { associations and associations of PLWA between } 2002 \text { and } 2006 \text {. } \\
\text { 2.-Facilitate access of essential services to } 50 \% \text { of PLWA and their } \\
\text { families between } 2002 \text { and } 2006 \text {. } \\
\text { 3.-Facilitate access for young girls and women to socio-economic } \\
\text { opportunities between } 2002 \text { and } 2006 \text {. } \\
\text { 4.- Popularize the existing laws on population and promotion of } \\
\text { women and young girls' rights. }\end{array}$ \\
\hline
\end{tabular}




\begin{tabular}{|c|c|c|}
\hline & $\begin{array}{l}\text { and girls. } \\
\text { 4.-National Human rights policy index. }\end{array}$ & \\
\hline $\begin{array}{l}\text { 5.Strengthen partnership } \\
\text { and national capacities } \\
\text { of MNP implementation } \\
\text { and coordination } \\
\text { structures between } 2002 \\
\text { and } 2006\end{array}$ & $\begin{array}{l}\text { 1.-National Budget funds spent for } \\
\text { HIV/AIDS programmes } \\
\text {-Ratio of Government funds to funds or } \\
\text { spending by other sources on HIV/AIDS } \\
\text { programmes } \\
\text { 2.-CDLS and CPLS plans of actions } \\
\text { developed in collaboration with partners } \\
\text { 3.-Supervision and monitoring visits by } \\
\text { the CNLS to the CPLS }\end{array}$ & $\begin{array}{l}\text { 1.-Make HIV/AIDS control partnership mechanisms functional. } \\
\text { 2.-Make HIV/AIDS control coordination and implementation } \\
\text { structures functional between } 2002 \text { and } 2006 \\
\text { 3.-Ensure better coordination of the development of MNP activities. }\end{array}$ \\
\hline
\end{tabular}

